A.S. is indebted to the Studienstiftung des deutschen Volkes for a graduate fellowship, and P.P.P. is grateful to the Consiglio Nazionale della Ricerche and Regione Autonoma della Sardegna for grants. The authors thank Dr. B. Knieriem, Universität Göttingen, for carrying out the semiempirical and ab initio calculations. The collaboration between the groups in Orsay and Göttingen was made possible through a mobility grant by the ANRT-DAAD within the PROCOPE program.

Registry No. 1, 13837-45-1; 2a, 22935-31-5; 2b, 73680-08-7; 2c, 130715-07-0; 2d, 130715-08-1; 2e, 32364-41-3; 2f, 136964-21-1; 3a, 40791-85-3; 3e, 136964-25-5; 4e, 139633-85-5; 5a, 81834-42-6; 5b, 139633-86-6; 5e, 139633-87-7; 6a, 73680-09-8; 6b, 73680-10-1; 6d, 136964-42-6; 8a, 57951-63-0; 8c, 139633-88-8; 8e, 57951-60-7; 9, 74592-36-2; 10a, 28974-51-8; 10b, 130715-09-2; 10c, 139633-89-9; 11a, 70624-84-9; 11b, 136964-29-9; 12, 38387-33-6; 13, 139633-90-2; 14, 83662-45-7; 15, 75111-08-9; 16, 130715-11-6; 16', 112519-20-7; 17, $130715-12-7$; 18, 139633-91-3; 19, 24509-88-4; 20, 758-66-7; 21, 22539-80-6; 22, 1191-16-8; 27', 130715-13-8; 28, 130715-14-9; 29, $130715-16-1 ; 30,130715-15-0 ; 31,130715-18-3$; 32, 130715-17-2; 33,
69555-14-2; 34, 136964-35-7; 35, 139633-92-4; 36, 136964-38-0; 38 , 136964-32-4; 39, 69447-96-7; 40, 136964-33-5; 41, 136964-36-8; 42, 136964-30-2; 43, 136964-37-9; 44, 136964-26-6; 45-Me, 139633-93-5; 45-Ph, 139633-94-6; 46, 136964-27-7; 47, 136964-28-8; 48, 50462-85-6; $49,81798-12-1 ; 51,16958-35-3 ; 55,139633-95-7 ; 56,136964-34-6 ; 57$, 136964-31-3; 65-H, 42311-14-8; 65-Me, 139633-96-8; 65-TMS, 139633-97-9; 66-H, 139633-98-0; 66-Me, 139633-99-1; 66-TMS, 139655-48-4; 66- $\mathrm{Ph}, 18712-30-6 ; 67,21777-85-5 ; 70,139634-00-7 ; 71$, 139634-01-8; dppe, 1663-45-2; Pd(dba), $32005-36-0 ;(S)-(-)$-BINAP, 76189-56-5; $\mathrm{Pd}\left(\mathrm{PPh}_{3}\right)_{4}, 14221-01-3 ; \mathrm{PhCH}=\mathrm{CHCH}_{2} \mathrm{OH} \cdot \mathrm{Na}, 63336-$ 41-4; $\mathrm{PhZnCl}, 28557-00-8$; CuI, 7681-65-4; $n$-BuZnCl, 42930-39-2; $\mathrm{MeZnCl}, 5158-46-3 ; \mathrm{NiCl}_{2}\left(\mathrm{PPh}_{3}\right)_{2}$, 14264-16-5; 2-bromo-2-propene, 557-93-7; 1-chloro-1-(trichlorovinyl)cyclopropane, 82979-27-9; sodium diethyl malonate, 996-82-7; sodium dimethyl malonate, 18424-76-5; sodium dimethyl allylmalonate, 139634-02-9; sodium dimethyl propargylmalonate, 107201-05-8; sodium 2-methoxycarbonylcyclopentanoate, 139634-03-0; 2-methyl-1,3-cyclopentanedione, 765-69-5; sodium methyl 2-phenylsulfonylacetate, 60729-65-9; potassium acetate, 127-08-2; potassium phthalimide, 1074-82-4; sodium dimethyl 2-cyclopropylideneethane malonate, 139634-04-1; 5-methyl-4-hexen-3-one, 13905-10-7.

\title{
Diastereofacial Selectivity in Reactions of Substituted Cyclohexyl Radicals. An Experimental and Theoretical Study
}

\author{
W. Damm, ${ }^{\dagger}$ B. Giese, ${ }^{*},{ }^{\dagger}$ J. Hartung, ${ }^{\ddagger}$ T. Hasskerl, ${ }^{\dagger}$ K. N. Houk,${ }^{\S}$ O. Hüter, ${ }^{\dagger}$ and \\ H. Zipse ${ }^{*,+}$ \\ Contribution from the Institute of Organic Chemistry, University of Basel, St. Johanns-Ring 19, \\ CH-4056 Basel, Switzerland, Institute of Organic Chemistry, TH Darmstadt, Petersenstrasse 22, \\ D-6100 Darmstadt, Germany, and Department of Chemistry and Biochemistry, University of \\ California-Los Angeles, Los Angeles, California 90024. Received November 18, 1991
}

\begin{abstract}
The diastereofacial selectivity in reactions of a series of alkyl-substituted cyclohexyl radicals has been investigated. In additions of cyclohexyl radicals to alkenes, it has been found that only substituents bound at the olefinic center being attacked by the radical influence the equatorial-axial selectivity. Substituents bound to the radical center or axial substituents $\beta$ to the radical center lead to increased axial attack. Equatorial $\beta$-substituents or axial $\gamma$-substituents increase the amount of equatorial attack. The same trends are observed for halogen and hydrogen abstraction reactions; the amount of axial reaction product is usually somewhat higher than in the addition reactions. The stereoselectivities can be explained with steric and torsional effects very similar to those suggested for nucleophilic addition reactions to cyclohexanones. A MM2 force field has been parameterized to gain further insight into the stereochemistry of the reaction.
\end{abstract}

\section{Introduction}

Substituent effects on the stereoselectivities of addition reactions to cyclic ketones have been investigated by several groups, and a number of models have been developed to rationalize the observed results. ${ }^{1}$ For the majority of the systems studied so far the torsional strain transition-state model ${ }^{2}$ can explain the stereochemical outcome of the reactions, even though the effects of remote functionalization by polar groups are still intensely discussed. ${ }^{1,3}$ equatorial
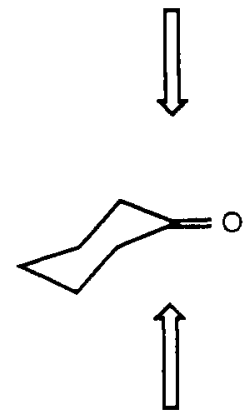

axial equatorial

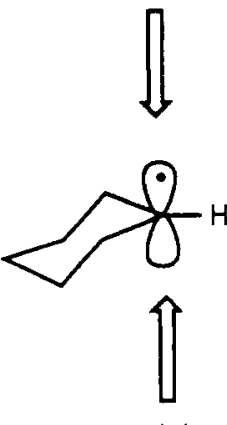

axial
University of Basel.

TH Darmstadt.

University of California.
Cyclic radicals are closely related to ketones topologically but have been studied much less. ${ }^{4 a}$ The largest body of information was obtained from carbohydrate radicals in addition and atom

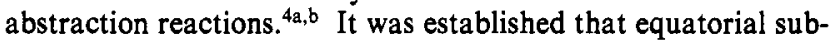
stituents adjacent to the radical center ( $\beta$-substituents) lead to increased equatorial product formation, whereas axial substitution enhances the formation of axial products. The influence of remote functional groups on the diastereoselectivity through electronic effects has been investigated just recently. ${ }^{4 c}$ Another stereoelectronic effect was found to be of major importance in carbohydrates bearing the radical center at $\mathrm{C}-1$. In these systems the ring oxygen atom adjacent to the radical center leads to predominantly axial attack. ${ }^{4 a, b}$

However, the detailed analysis of substituent effects is complicated by the large number of substituents present in carbohydrates. We therefore decided to study the effects of ring substitution by investigating the reactions of mono- and disubstituted cyclohexyl radicals.

(1) (a) Wu, Y.-D.; Tucker, J. A.; Houk, K. N. J. Am. Chem. Soc. 1991, 113,5018 and references therein. (b) Wu, J.-D.; Houk, K. N. J. Am. Chem. Soc. 1987, 109, 908.

(2) (a) Cherest, M.; Felkin, H.; Prudent, N. Tetrahedron Lett. 1968, 2199. (b) Anh, N. T. Fortschr. Chem. Forschung. 1980, 88, 145.

(3) (a) Cieplak, A. S.; Tait, B. D.; Johnson, C. R. J. Am. Chem. Soc. 1989, 111, 8447. (b) Xie, M.; le Noble, W. J. J. Org. Chem. 1989, 54, 3836.

(4) (a) Giese, B. Angew. Chem., Int. Ed. Engl. 1989, 28, 969 and references therein. (b) Vasella, A.; Baumberger, F. Helv. Chim. Acta 1983, 66, 2210. (c) Bodepudi, V. R.; le Noble, W. J. J. Org. Chem. 1991, 56, 2001. (d) Curran, D. P.; Chen, M.-H.; Kim, D. J. Am. Chem. Soc. 1989, 111, 6265. 


\section{Results}

Preparation of Radical Precursors. The 4-tert-butylcyclohexyl halides ${ }^{5,6}$ and (4-tert-butylcyclohexyl)mercury bromide ${ }^{7}$ were synthesized following literature methods. Alcohol 1 was used as the starting material ${ }^{8}$ for 4-tert-butyl-1-methylcyclohexyl radicals. This alcohol was converted to bromide 2 in high yield by reaction with dry $\mathrm{HBr}$ gas without isomerization.

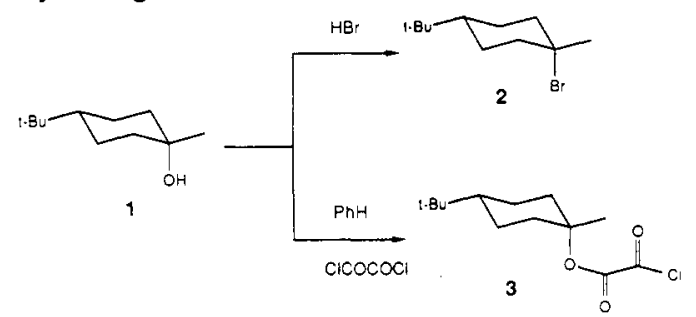

For halide atom transfer reactions the alcohol was first converted to the oxalyl monochloride ester 3 by treatment with oxalic chloride. The monoester can be used to generate the corresponding substituted cyclohexyl radicals by the method of Barton and Crich. ${ }^{9}$ For the synthesis of 4-tert-butyl-2-methylcyclohexanols, $o$-cresol was alkylated with tert-butyl chloride ${ }^{10}$ followed by reduction with Raney nickel. ${ }^{11}$ This yields a mixture of the four diastereomers $\mathbf{4 a - 7 a}$.
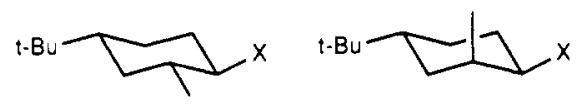

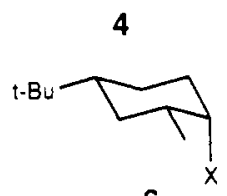

6

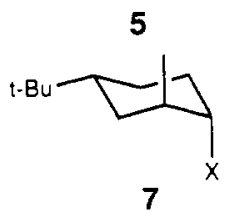

$$
\begin{aligned}
& a: X=O H \quad b: X=O \\
& c: X=1 \quad d: X=B r \quad \text { e : } X=C l
\end{aligned}
$$

While cis-4-tert-butyl-cis-2-methylcyclohexanol (6a) can be separated from the mixture by column chromatography on alumina, the remaining three isomers were separated by MPLC. The separate alcohols were converted to imidazoylthiocarbonyl urethanes $4 b-7 b$ or to the iodides $4 c-7 c$ or the bromides $4 d-7 d$ as radical precursers. ${ }^{12}$ Iodide $\mathbf{1 0}$ was synthesized in a three-step procedure. Ketone 9 was obtained by copper(I)-catalyzed addition of tert-butylmagnesium bromide to 2-cyclohexenone (8). Reduction with $\mathrm{NaBH}_{4}{ }^{13}$ and reaction with iodine, imidazole, and triphenylphosphine ${ }^{14}$ gave iodide 10 .

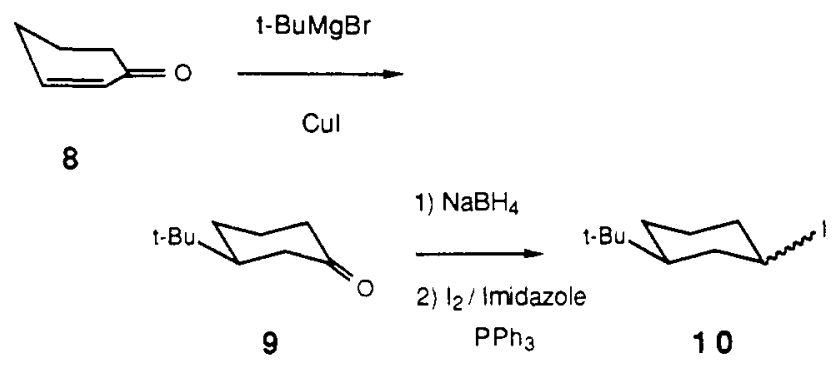

(5) Gore, J.; Place, P.; Roumestrant, M. L. J. Chem. Soc., Chem. Commun. 1973, 821

(6) Eliel, E. L.; Haber, R. G. J. Org. Chem. 1959, 24, 143.

(7) Alexandrou, N. E. J. Organomet. Chem. 1966, 5, 301.

(8) Elakovich, S. D.; Traynham, J. G. J. Org. Chem. 1973, 38, 873.

(9) Crich, D;; Fortt, S. M. Synthesis 1987, 35.

(10) Baur, A, Ber. Disch. Chem. Ges. 1894, 27, 1614

(11) Darzens, G.; Rost, H. Compt. Rend. Acad. Sci. 1911, 152, 608

(12) Barton, D. H. R.; McCombie, S. W. J. Chem. Soc., Perkin Trans I 1975, 1574 .

(13) Hückel, W.; Thiele, K. Chem. Ber. 1961, 94, 2027.
The cyclohexyl ring of 4-tert-butyl-3-methylcyclohexanone ${ }^{15}$ is known not to adopt a chair conformation with an axial methyl group because of steric compression between the ring substituents. To investigate the effect of an axial methyl group in the 3-position to the radical center ( $\gamma$-substituent), we therefore chose the more rigid decalin system 13. 10-Methyl-trans-decalin-3-one (11) ${ }^{16}$ was brominated, subsequently reduced with sodium borohydride, epoxidized to the 10-methyl-trans-decalin 2,3-epoxide, and opened with $\mathrm{LiAlH}_{4}$ in a diaxial fashion to give 10 -methyl-2 $\beta$-hydroxytrans-decalin (12).

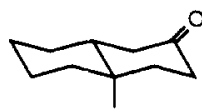

11
1) $\mathrm{Br}_{2} / \mathrm{ACOH}$
2) $\mathrm{NaBH}_{4}$
3) $\mathrm{KOH} / \mathrm{i}-\mathrm{PrOH}, \triangle$
4) $\mathrm{LiAlH}_{4}$

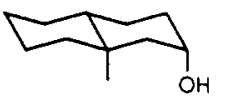

12
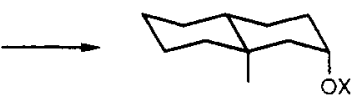

13
This protocol has already been applied successfully to ketone transposition reactions in steroid systems. ${ }^{17}$ Alcohol 12 was converted to radical precursors 13 as described above for alcohols 1 and $\mathbf{4 a - 7 a . 9 , 1 2}$

Addition Reactions to Alkenes. All the addition reactions were carried out with the bromides, iodides, or thiocarbonylurethanes as precursors under standard tin hydride reaction conditions. The alkene was used in 2-10-fold excess with respect to the precursor and benzene or toluene were employed as solvents at $80-90^{\circ} \mathrm{C} .^{18}$

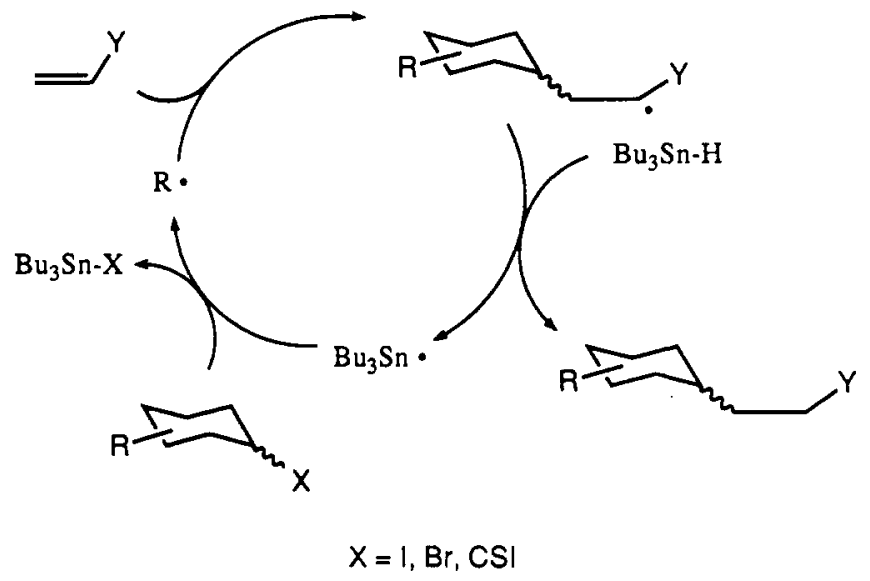

The reaction mixtures were worked up utilizing $\mathrm{KF}$ or $\mathrm{I}_{2} / \mathrm{KF}$ treatment to remove tin compounds. Subsequent column chromatography yields the products as usually unpolar, colorless oils. Isomer ratios were determined by gas chromatographic measurements prior to workup. In cases in which this was not possible, the relative amounts of each isomer were determined by ${ }^{1} \mathrm{H}-\mathrm{NMR}$ or inverse-gated ${ }^{13} \mathrm{C}$-NMR measurements after chromatography. The stereochemical assignment of the isomers is mainly based on ${ }^{13} \mathrm{C}-\mathrm{NMR}$ data. By use of the ${ }^{13} \mathrm{C}-\mathrm{NMR}$ additivity method, spectra were calculated for the equatorial and axial isomers. The main differences are caused by $\gamma$-effects in axial isomers, which shift the signals of axial substituents and the $\gamma$-ring atoms upfield by 10-12 ppm. This allows the identification of all addition

(14) Garegg, J. P.; Samuelsson, B. J. Chem. Soc., Perkin Trans I 1980, 2866.

(15) Djerassi, C.; Konopelski, J. P.; Sundararaman, P.; Barth, G. J. Am. Chem. Soc. 1980, 102, 2737.

(16) Casadevall, A.; Casadevall, E.; Lasperas, M. Bull. Soc. Chim. Fr. 1968, 11,4506 .

(17) Gurst, J. E.; Djerassi, C. J. Am. Chem. Soc. 1964, 86, 5542.

(18) Regitz, M.; Giese, B.C-Radikale, Houben-Weyl; Thieme: Stuttgart, 1989; Vol. E19a. 
Table I. Equatorial-Axial Selectivities and Yields for Addition Reactions of the 4-tert-Butylcyclohexyl Radical to Alkenes (Calculated Values in Parentheses)

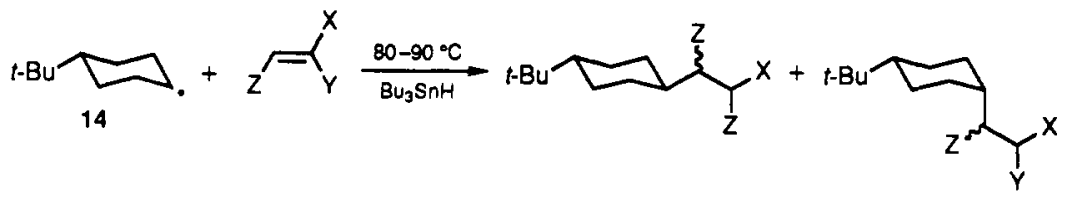

\begin{tabular}{|c|c|c|c|c|c|c|c|c|}
\hline & \multicolumn{8}{|c|}{ alkene } \\
\hline $\begin{array}{l}e: a \\
\text { yield }\end{array}$ & $\begin{array}{l}51: 49 \\
25 \%\end{array}$ & $\begin{array}{l}53: 47 \\
33 \%\end{array}$ & $\begin{array}{l}55: 45(53: 47) \\
80 \%\end{array}$ & $\begin{array}{l}60: 40 \\
96 \%\end{array}$ & $\begin{array}{l}74: 26(68: 32) \\
77 \%\end{array}$ & $\begin{array}{l}44: 56 \\
42 \%\end{array}$ & $\begin{array}{l}73: 27 \\
21 \%\end{array}$ & $\begin{array}{l}88: 12 \\
12 \%\end{array}$ \\
\hline
\end{tabular}

Table II. Equatorial-Axial Selectivities and Yields for Addition Reactions of Disubstituted Cyclohexyl Radicals (Calculated Values In Parentheses)

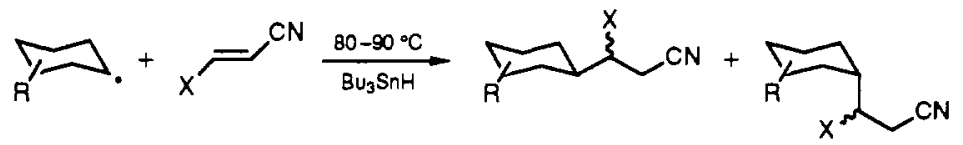

\begin{tabular}{|c|c|c|c|c|c|c|}
\hline \multirow[b]{2}{*}{$X$} & \multicolumn{6}{|c|}{$e: a$} \\
\hline & 15 & 16 & 17 & 18 & 19 & 20 \\
\hline $\begin{array}{l}\mathrm{H} \\
\mathrm{Me} \\
\mathrm{CN}\end{array}$ & $\begin{array}{l}36: 64(35: 65), 65 \% \\
60: 40(53: 47), 38 \% \\
56: 44(46: 54), 32 \%\end{array}$ & $\begin{array}{l}79: 21(79: 21), 17 \% \\
>95: 5(92: 8), 46 \% \\
>95: 5(89: 11), 29 \%\end{array}$ & $\begin{array}{l}10: 90(8: 92), 66 \% \\
17: 83(13: 87), 60 \%\end{array}$ & $\begin{array}{l}56: 44(57: 43), 22 \% \\
(76: 24)\end{array}$ & $\begin{array}{l}97: 3(99: 1), 50 \% \\
>98: 2(>99: 1), 43 \% \\
>98: 2(>99: 1) 29 \%\end{array}$ & $\begin{array}{l}30: 70^{a}(42: 58) \\
65: 35^{a}(60: 40)\end{array}$ \\
\hline
\end{tabular}

${ }^{a}$ Reaction at room temperature in DMF utilizing a vitamin $\mathbf{B}_{12}$ catalyzed reduction method. ${ }^{20}$

Table III. Equatorial-Axial Selectivities and Yields for Abstraction Reactions of Disubstituted Cyclohexyl Radicals

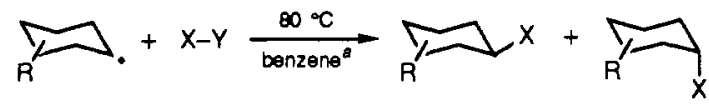

\begin{tabular}{|c|c|c|c|c|c|}
\hline \multirow[b]{2}{*}{$X-Y$} & \multicolumn{5}{|c|}{$e: a$} \\
\hline & 14 & 15 & 16 & 18 & 19 \\
\hline $\begin{array}{l}\mathrm{DSnBu} u_{3} \\
\mathrm{BrCCl}_{3} \\
\mathrm{CCl}_{4}\end{array}$ & $\begin{array}{l}30: 7019 \% \\
31: 69 \\
23: 77\end{array}$ & $\begin{array}{l}11: 89,{ }^{b} 73 \% \\
8: 92\end{array}$ & $\begin{array}{l}44: 56,39 \% \\
49: 51,38 \% \\
44: 56,77 \%\end{array}$ & $\begin{array}{l}15: 85,42 \% \\
15: 85,90 \%\end{array}$ & $\begin{array}{l}91: 9,40 \% \\
91: 9,73 \%\end{array}$ \\
\hline
\end{tabular}

${ }^{a}$ For $\mathrm{Cl}$ atom transfer reactions $\mathrm{CCl}_{4}$ was used as solvent at reflux temperature. ${ }^{b} \mathrm{HSnBu}_{3}$ was used as trapping agent.

products as equatorial or axial isomers. In halogen abstraction reactions (see below), this method was complemented by ${ }^{1} \mathrm{H}-\mathrm{NMR}$ spectra of the product mixtures, which in all cases agreed with the ${ }^{13} \mathrm{C}$-NMR assignments. Only in the addition reactions of decalyl radicals, the assignments posed larger problems, since $\gamma$-effects were found to be only 2-3 ppm. This is, however, known from other axially 1,3-disubstituted cyclohexyl systems. ${ }^{26}$ The

(19) Ohloff, G.; Giersch, W.; Thommen, W.; Willhalm, B. Helv. Chim. Acta 1983, 66, 1343.

(20) Scheffold, R. In Modern Synthetic Methods; Salle \& Sauerländer: 1983.

(21) Spellmeyer, D. C.; Houk, K. N. J. Org. Chem. 1987, 52, 959.

(22) All calculations were carried out using GAUSSIAN 90: Frisch, M. J.; Head-Gordon, M.; Trucks, G. W.; Foresman, J. B.; Schlegel, H. B.; Raghavachari, K.; Robb, M. A.; Binkley, J. S.; Gonzalez, C.; Defrees, D. J.; Fox, D. J.; Whiteside, R. A.; Seeger, R.; Melius, C. F.; Baker, J.; Martin, R. L.; Kahn, L. R.; Stewart, J. J. P.; Topiol, S.; Pople, J. A. For geometry optimizations and frequency calculations, the 3-21G basis set was used with UHF wave functions. All stationary points were tested by frequency calculations.

(23) Houk, K. N.; Paddon-Row, M. N.; Spellmeyer, D. C.; Rondan, N. G.; Nagase, S. J. Org. Chem. 1986, $51,2874$.

(24) Broeker, J.; Houk, K. N.; Giese, B.; Zipse, H., manuscript in preparation.

(25) Taken from the $a b$ initio UHF/3-21G optimized geometry for the cyclohexyl radical. same trend is observed in halogen abstraction reactions, where the assignments are again supported by ${ }^{1} \mathrm{H}-\mathrm{NMR}$ spectra.

In the case of the addition product of 4-tert-butyl-1-methylcyclohexyl radicals to fumaronitrile the solid isomers were separated and identified by $\mathrm{X}$-ray crystal structure analysis. Literature data were only available for the adducts of 4-tert-butylcyclohexyl radicals to vinyl acetate. ${ }^{17}$ Stereoselectivities of reactions of the 4-tert-butylcyclohexyl radical have been determined for a variety of alkenes as listed in Table I. Results for addition reactions of disubstituted cyclohexyl radicals, including reactions of the cholester-3-yl radical obtained by Scheffold, ${ }^{20}$ are listed in Table II. Generally, all experiments have been repeated at least once with a different concentration of tin hydride to exclude the possibility of unequal trapping rates of the equatorial and axial adduct radicals. Only in the addition reaction to vinyl acetate were larger amounts of oligomeric products observed in the GC spectrum. The experiment has therefore been repeated with different concentrations of vinyl acetate as well, but this did not change the observed selectivity by a significant amount.

(26) Grover, S. H.; Stothers, J. B. Can. J. Chem. 1974, 52,870

(27) Green, F. D.; Chu, C. C.; Walia, J. Org. Chem. 1964, 29, 1285.

(28) Lambert, J. B.; Vagenas, A. R. Org. Magn. Reson. 1981, I7, 265.

(29) Allinger, N. L.; Yuh, Y. QCPE 1980, 12, 395. 


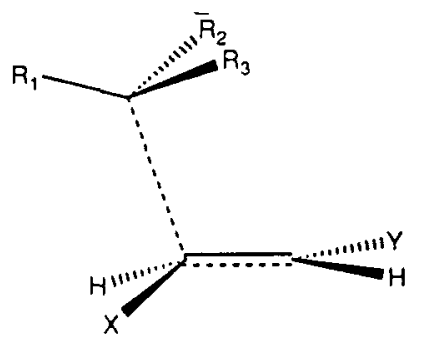

general structure

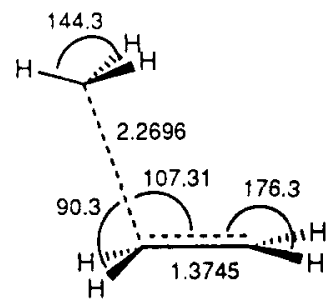

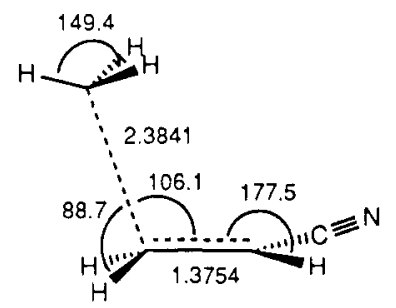
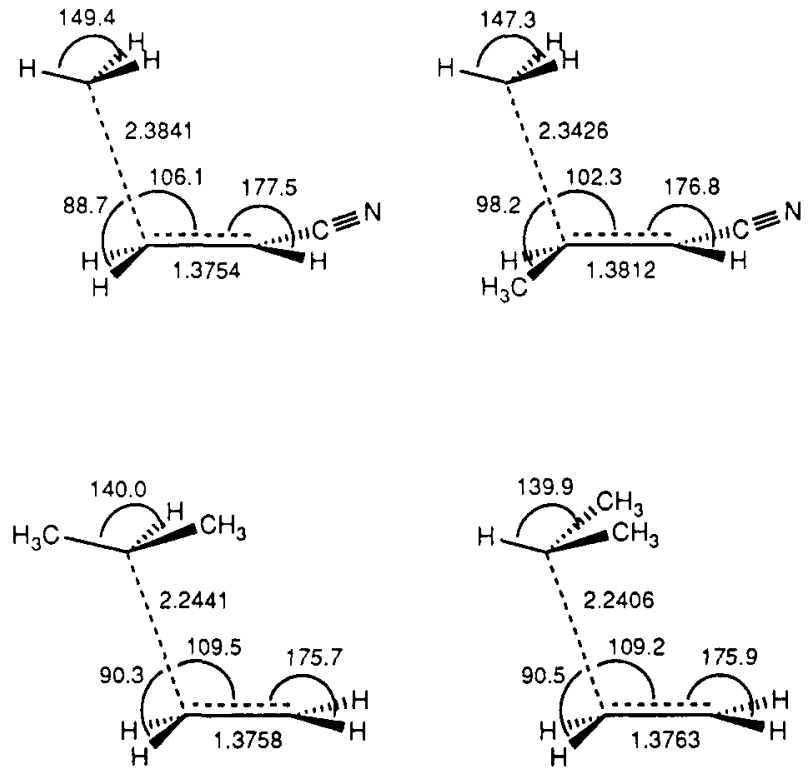
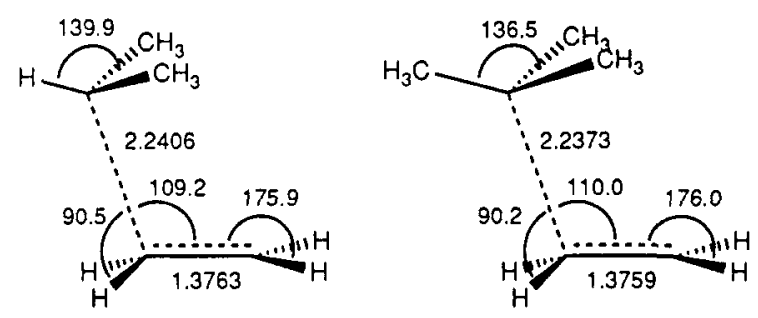

Figure 1. UHF/3-21G transition states for the addition of methyl radical to ethylene, acrylonitrile, crotonitrile, and fumarodinitrile and for the addition of isopropyl and tert-butyl radicals to ethylene.

Deuterium- and Halogen-Transfer Reactions. Reduction of the cyclohexyl radical precursors was accomplished by adding the halide or thiocarbonylurethane to a refluxing solution of tri- $n$ butyldeuteriostannane in benzene together with small amounts of AIBN as initiator. For halogen abstration reactions the cyclohexanols were treated first with oxalyl chloride followed by addition to a benzene solution containing the halogen donor $\left(\mathrm{CCl}_{4}\right.$ or $\mathrm{BrCCl}_{3}$ ) and $N$-hydroxypyridine-2-thione sodium salt. ${ }^{9}$ In the case of chlorine abstraction, $\mathrm{CCl}_{4}$ was used as solvent. The selectivities obtained are collected in Table III.

Force Field for the Intermolecular Addition Reaction. Since the rationalization for the stereoselectivity in carbohydrate radical reactions is mainly based on steric grounds, we developed a MM2-parameter set for the calculation of transition states of the addition reaction of cyclic radicals to alkenes. A convenient starting point was provided by the transition-state parameter set for the intramolecular 5-hexenyl radical cyclization..$^{21}$ In this reference the general procedure for the computation of selectivities is discussed as well.

Ab Initio Calculations. The force field for intramolecular radical cyclizations was based on a series of transition-state structures for the addition of hydrocarbon radicals to alkyl-substituted alkenes determined by $a b$ initio methods. ${ }^{23}$ Since intermolecular radical addition reactions usually employ electron-poor alkenes, we conducted ab initio molecular orbital calculations ${ }^{22}$ on the transition states for the addition of methyl radical to crotononitrile and fumaronitrile. The results are shown in the upper part of Figure 1 together with the transition states for the addition to ethylene ${ }^{23}$ and acrylonitrile. ${ }^{24}$ Comparison of the length of the forming bond in these four transition states readily demonstrates that the distance between the radical and the terminal olefin carbon atom is larger for transition states of electron-deficient alkenes by at least $0.07 \AA$ as compared to that of the ethylene transition states. The second feature, in which significant differences can be found, is the angle of attack. For alkenes unsubstituted at the attacked alkene terminus, the angle of attack is about $107^{\circ}$. Methyl or cyano substituents at this center reduce this angle by $2-4^{\circ}$. Furthermore, this change is accompanied by an increase of the angle $\mathrm{C}_{\text {radical }} / \mathrm{C}_{\text {alkene }} / \mathrm{X}$ from $90^{\circ}$ for $\mathrm{X}=\mathrm{H}$ to $97-98^{\circ}$ for $\mathrm{X}=\mathrm{CH}_{3}$ or $\mathrm{X}=\mathrm{CN}$, where $\mathrm{X}$ is the substituent at the alkene. Presumably substituents at the attacked olefinic carbon atom repel the newly forming bond and by doing so reduce the angle of attack. The pyramidalization of the methyl radical and of the alkene center not being attacked are more or less constant throughout this series with substituted alkenes. As cyclohexyl radicals were studied experimentally, it was important

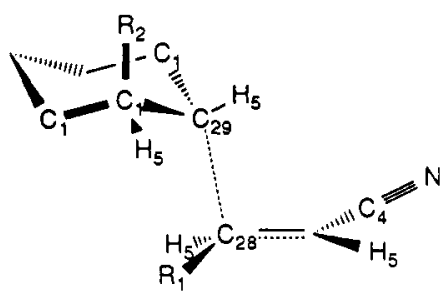

Figure 2. Transition-state model for the addition of cyclohexyl radical to alkenes.

to determine how the character of the radical influences the geometry of the transition state. For that reason the transition structures for the additions of isopropyl and tert-butyl radicals to ethylene have been calculated as well. In going from methyl to secondary and tertiary radicals, the length of the newly forming bond decreases and the pyramidalization of the radical and the angle of attack both increase. The pyramidalization of the olefinic center not being attacked and the angle $C_{\text {radical }} / C_{\text {alkene }} / \mathrm{H}$ remain virtually unchanged and are independent of the character of the radical.

Comparison of the deformed methyl or tert-butyl radical in the ground state, the transition state, and the product radical for addition to ethylene reveal one more fact important for the stereochemical discussion of transition states: more than half of the deformation that occurs in both radicals on going from ground state to product radical has already occurred in the transition state. Thus, the notion of an "early" transition state should rather be used in an energetic and not necessarily a geometric sense, indicating that only little energy is needed to deform the reactants into their transition-state geometry. Deformation of the attacked olefinic center is less advanced in the transition state: one-third of the overall geometrical change has occurred.

Parameterization of the MM2 Force Field. In Figure 2 the transition-state model for the addition of cyclohexyl radicals to alkenes is shown schematically together with the MM2 atom type numbers.

Generally standard MM2 atom types have been used. New atom types have been defined only for the radical center and the alkene carbon atom involved in the reaction. As shown by the ab initio transition state calculations, the radical center and the olefinic carbon atom not attacked can be treated to a good approximation as $\mathrm{C}_{\mathrm{sp}^{3}}$ and $\mathrm{C}_{\mathrm{sp}^{2}}$ carbons, respectively. It was, however, difficult to choose a value for the newly forming bond. A value of 2.34-2.38 $\AA$ would have been in accord with the ab initio results 
for the methyl radicals presented in Figure 1. Optimization of the transition states with a larger basis set for some other systems showed ${ }^{24}$ that the range of bond length for different alkenes could be somewhat smaller as compared to the UHF/3-21G results. In addition, the distance between secondary and tertiary radicals and the olefinic carbon in the transition states seemed to be slightly shorter as for methyl radicals. We therefore chose a value of 2.27 $\AA$ for the length of the forming bond together with the original force constant. ${ }^{21}$ All the other bond lengths were kept at the values used for the intramolecular 5-hexenyl cyclization. The choice of bond angles has been much less problematic. The angle of attack varied between $102^{\circ}$ and $110^{\circ}$ for different alkenes and radicals as shown in Figure 1. Calculation of selectivities with values ranging from $99^{\circ}$ to $111^{\circ}$ showed that this parameter had a very limited influence on the results obtained. We therefore employed an angle of $107.0^{\circ}$. Angles $\mathrm{C}_{29} / \mathrm{C}_{28} / \mathrm{R}_{1}$ were then chosen according to the ab initio UHF $/ 3-21 \mathrm{G}$ results. Thus, we used $90.3^{\circ}$ for $\mathrm{C}_{29} / \mathrm{C}_{28} / \mathrm{H}, 98.2^{\circ}$ for $\mathrm{C}_{29} / \mathrm{C}_{28} / \mathrm{CH}_{3}$, and $96.6^{\circ}$ for $\mathrm{C}_{29} /$ $\mathrm{C}_{28} / \mathrm{CN}$. The force constants were again kept at their original values. $^{21}$ As a final step the potential parameters for the atom type sequences $\mathrm{C}_{1} / \mathrm{C}_{1} / \mathrm{C}_{29} / \mathrm{C}_{28}, \mathrm{C}_{1} / \mathrm{C}_{1} / \mathrm{C}_{29} / \mathrm{C}_{1}, \mathrm{C}_{1} / \mathrm{C}_{1} / \mathrm{C}_{29} / \mathrm{H}_{5}$, and $\mathrm{H}_{5} / \mathrm{C}_{1} / \mathrm{C}_{29} / \mathrm{H}_{5}$ were varied to minimize the energy difference between experimental and calculated selectivities. Selectivities were computed by first calculating all possible minimum-energy structures for the system under investigation. For the addition of radicals 14 and $\mathbf{1 5}$, six transition structures were found. For the addition of chiral radicals 16-20,12 structures were found, even though a larger number of structures has been investigated. Transition structures with nonchair ring conformations have been checked for addition reactions of radical 17, but their energies were found to be much higher. All of the low-energy transition structures (within $3.5 \mathrm{kcal} / \mathrm{mol}$ ) were then included in a Boltzmann distribution calculation at the temperature at which the selectivity to be computed has been determined experimentally. A vibrational analysis has not been performed and entropic contributions to the diastereoselectivity have been included only through the parameterization procedure, in which differences in MM2 strain energies are compared to experimental free energies (from product ratios).

The experimental results used for this purpose were taken from colums 1, 2, and 6 in Table II, and the selectivities for the additions of the 4-tert-butylcyclohexyl radical to acrylonitrile and crotononitrile were taken from Table I. The optimized potential parameters gave cyclohexyl rings somewhat flatter as compared to the situation with the original parameters. ${ }^{21}$ The calculated selectivities with this optimized parameter set are shown in Table II in parenthesis together with the experimental selectivities. Furthermore, the force field was used to predict isomer ratios for the addition of a variety of alkyl-substituted cyclic radicals to different alkenes. As selectivities were predicted to be especially large for systems with axial substituents $\beta$ or $\gamma$ to the radical center, we investigated experimentally the corresponding systems shown in columns 3 and 5 of Table II.

In addition reactions of the chiral radicals 16-19 to fumaronitrile and crotononitrile, the equatorial and axial addition products now consist of two diastereomers, which differ in their relative stereochemistry at the newly formed tertiary center. Thus, in the addition of radical $\mathbf{1 6}$ to crotononitrile and fumaronitrile, only equatorial addition product could be isolated, which consists of two diastereomers at $\mathrm{C} 3$ in a ratio of $55: 45$ and 54:46, respectively. The "face selectivity" therefore seems to be rather low. This is in accord with the force field predictions, which give diastereomeric ratios close to unity for all the reactions that have been investigated experimentally. As determination of face selectivity requires inverse-gated ${ }^{13} \mathrm{C}$-NMR measurements for all products, this aspect of addition stereoselectivity was not investigated further.

\section{Discussion}

Acrylonitrile attacks the axial and the equatorial face of 4tert-butylcyclohexyl radical (14) at about the same rate (Table I). It is somewhat surprising that the axial approach competes at all with the equatorial one since one should assume that axial

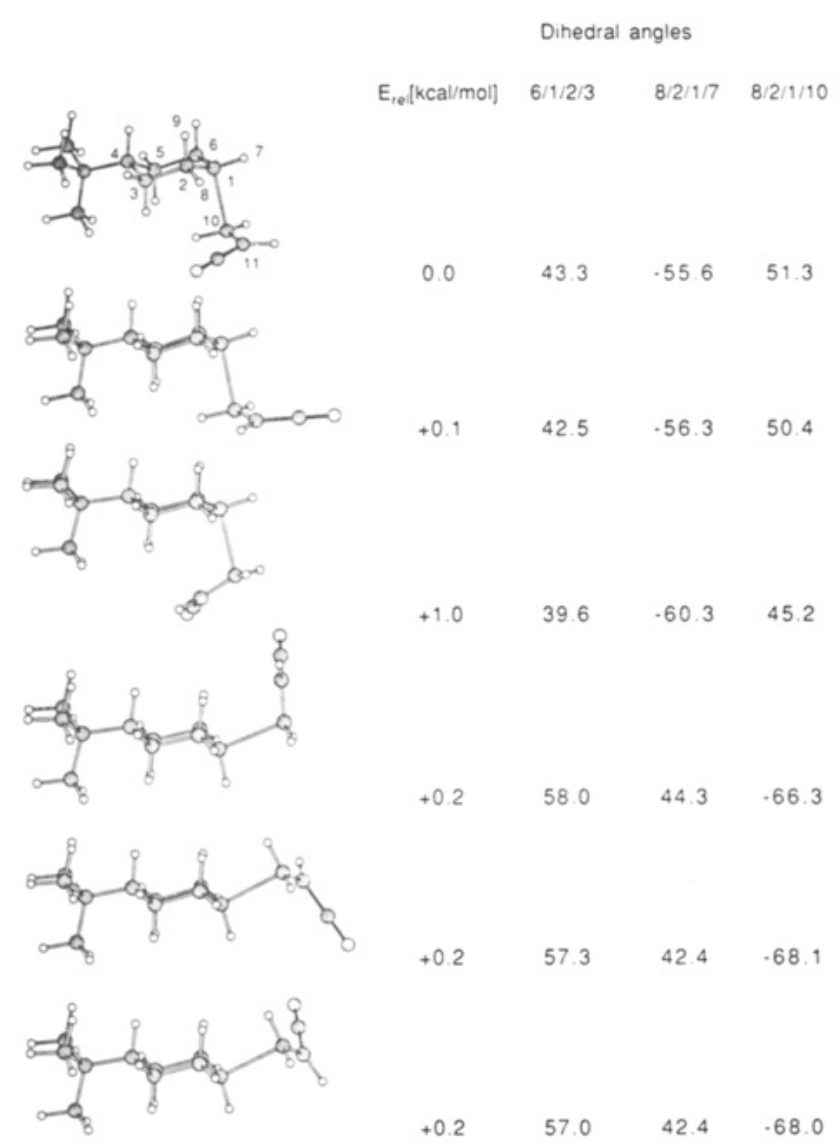

Figure 3. Transition states for the addition of the 4-tert-butylcyclohexyl radical (14) to acrylonitrile as calculated by the MM2 force field.

transition states are hampered by 1,3-diaxial interactions with the "bottom" face of the cyclohexyl ring. Inspection of the six MM2-transition-state structures in Figure 3 reveals that interactions between the bottom side of the cyclohexyl ring and the alkene are especially large for the conformer in which the alkene double bond is located directly under the ring.

This transition state is about $1 \mathrm{kcal} / \mathrm{mol}$ higher than the most favorable transition-state conformation and therefore contributes only little to the calculated selectivity. Since axial and equatorial products are formed in almost equal amounts, a compensating effect must be present to hinder the equatorial approach. On comparison of dihedral angle parameters in Figure 3, torsional effects can be identified to a similar extent as found for the nucleophilic additions to cyclohexanones. ${ }^{1}$ This torsional strain can best be viewed as the ring deformation indicated by dihedral angles $\mathrm{C}_{6} / \mathrm{C}_{1} / \mathrm{C}_{2} / \mathrm{C}_{3}$ and by the degree of staggering of adjacent bonds as indicated by the angle $\mathrm{H}_{8} / \mathrm{C}_{2} / \mathrm{C}_{1} / \mathrm{H}_{7}$. While the ring dihedral angle varies around $43^{\circ}$ for the energetically favorable axial transition states, it has to be enlarged to $57-58^{\circ}$ for the equatorial ones. This has to be compared to a value of $49^{\circ}$ in the cyclohexyl radical. ${ }^{25}$ Partial eclipsing is seen for the $\mathrm{H}_{8} / \mathrm{C}_{2}$ and $\mathrm{C}_{1} / \mathrm{H}_{7}$ bonds. While in axial transition structures almost perfect staggering is found with a dihedral angle of $56^{\circ}$, the bonds are separated by only $42-44^{\circ}$ in the equatorial transition states. The concept of torsional strain can be rationalized as well if the transition state for the addition of the isopropyl radical to ethylene is used to construct the possible structures for addition reactions of cyclohexyl radicals. As is pointed out with dashed lines in Figure 4, the axial transition states for cyclohexyl addition can be generated by replacing the hydrogens gauche to the forming bond (and anti to the hydrogen atom bound to the radical center) by a chain of three methylene groups. As these two hydrogens are aligned in a parallel fashion, there is no strain induced into the ring.

Replacing the two hydrogen atoms anti to the forming bond by a trimethylene chain leads to a strained equatorial transition state since these two hydrogens point away from each other. This 

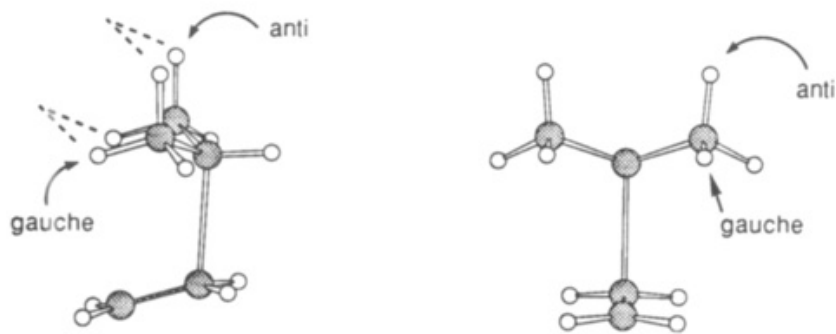

Figure 4. $C_{s}$ symmetrical ab initio UHF/3-21G transition structure for addition of the isopropyl radical to ethylene.

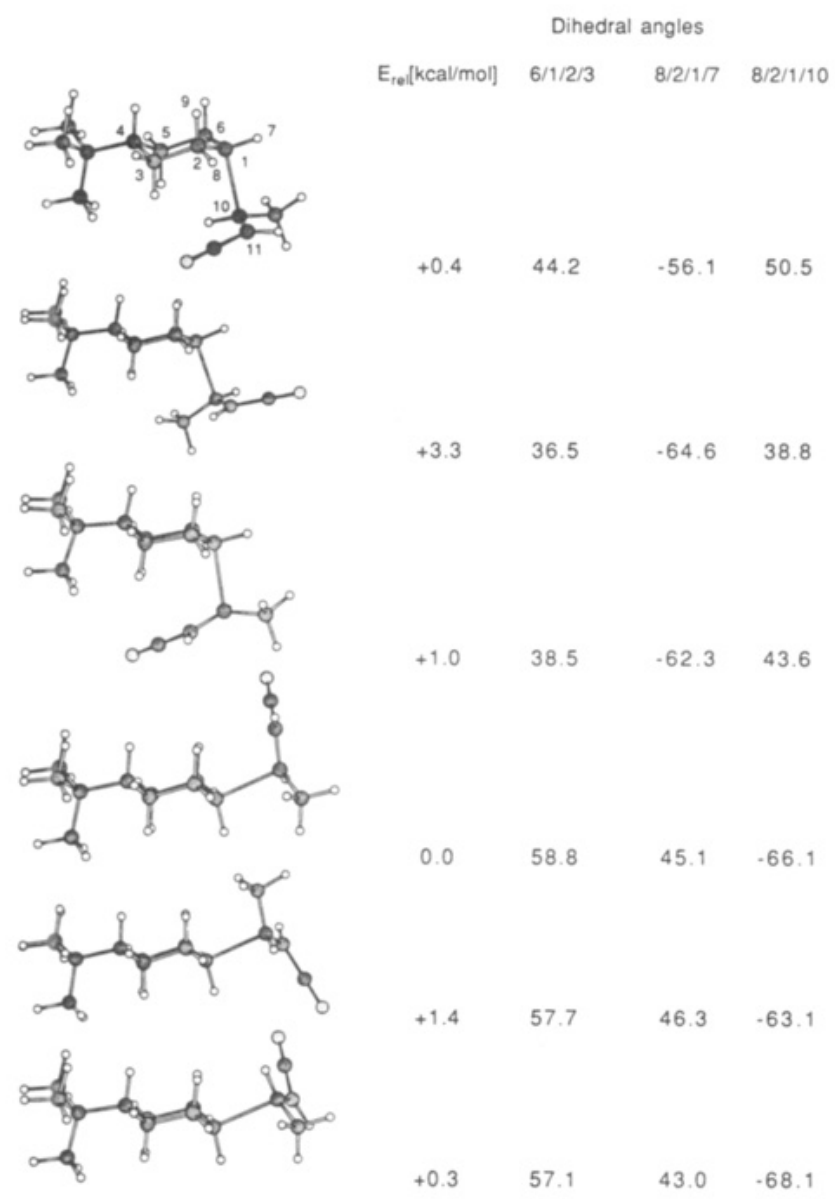

Figure 5. Transition states for the addition of the 4-tert-butylcyclohexyl (14) radical to crotonitrile as calculated by the MM2 force field.

strain can be relieved by deformation of the ring, which in turn leads to eclipsing interactions at the radical center. It is indeed striking how closely the transition states for nucleophilic additions to cyclic ketones resemble the case of cyclohexyl radical additions to alkenes and how similar the isopropyl plus ethylene system is to the addition of $\mathrm{LiH}$ to acetone.'

Effects of Alkene Substitution. The effects of substituents at the olefinic carbon atom that is attacked are shown in Table I. In each case the amount of equatorial product is enhanced, and the degree of enhancement depends on the size of the substituent. With the small cyano group the change in selectivity from acrylonitrile $(e: a=55: 45)$ to fumaronitrile $(e: a=60: 40)$ is only small. The effect increases with methyl substitution $(e: a=74: 26$ for crotononitrile and 73:27 for diethyl ethylidenemalonate) and becomes significant in the isopropyl case, where an $e: a$ ratio of $88: 12$ was found. The reason for this trend can clearly be identified on comparison of Figure 3 with Figure 5, where the six MM2 transition states for the addition of the 4-tert-butylcyclohexyl radical (14) to acrylo- and crotonitrile are collected. From the first two axial transition states in Figure 3, which have similar energies, only the first is left to contribute to the calculated selectivity in Figure 5. In the second transition state the methyl

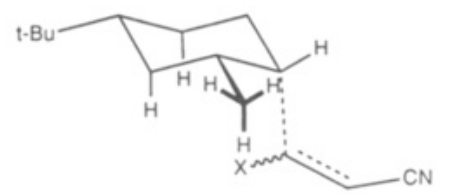<smiles>[Y]C1CCC(C=CC)CC1C</smiles>

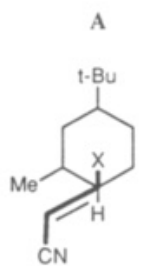

D

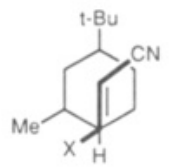

B

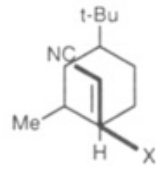

E<smiles>CC1CCCC(C#N)C1C#N</smiles>

C<smiles>[Y]C1(CC)CCC(Br)CC1C</smiles>

$\mathbf{F}$
Figure 6. Effect of equatorial $\beta$-methyl substituents.

group of crotononitrile is located directly under the ring, which elevates the energy relative to other conformers by more than 3.0 $\mathrm{kcal} / \mathrm{mol}$. This effect is much larger than the energy increase of about $1.4 \mathrm{kcal} / \mathrm{mol}$ for the second equatorial transition structure in Figure 5.

$\alpha$-Substitution at the Radical. The selectivities for the addition of the 4-tert-butyl-1-methylcyclohexyl radical (15) to three different alkenes are given in the first column of Table II. Selectivities in intramolecular cyclization reactions of similar systems have been investigated by Curran and by Clive. ${ }^{4 \mathrm{~d}}$

Comparison with the corresponding results for the 4-tert-butylcyclohexyl radical (14) in Table I reveals that all three alkenes increase the amount of axial isomer in reaction with radical $\mathbf{1 5}$. Inspection of the three MM2 transition states shows that the axial transition states for the 4-tert-butyl-1-methylcyclohexyl radical addition differ only slightly from those for the 4-tert-butylcyclohexyl system. In these structures the additional methyl group at the radical center occupies an equatorial position with almost perfect staggering with respect to the adjacent bonds. Transition states for equatorial attack, however, show large changes, since the methyl group now occupies an axial position, which leads to 1,3-diaxial interactions in all possible conformations.

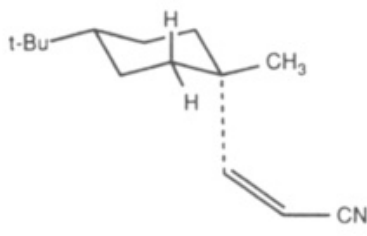

axial

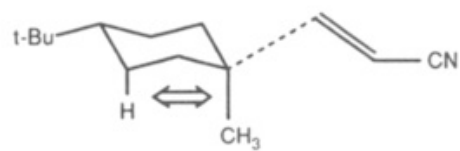

equatorial
$\beta$-Substitution at the Radical. Moving the methyl group from the radical center to the equatorial position at the adjacent carbon atom leads to pronounced reduction of axial product formation (Table II). While the effect is quite significant already for acrylonitrile, only equatorial product can be found for alkenes substituted at the attacked olefinic center. Inspection of the MM2 model again offers an explanation. While equatorial transition states hardly change, the ring methyl group functions as an additional ring $\gamma$-carbon atom for axial transition structures as depicted in Figure 6.

Here, the six transition states are shown from the bottom side, which gives a clear view of the different possible orientations of the alkene relative to the cyclohexyl ring. From Figure 3 it already became obvious that structures like B and $\mathrm{E}$, in which the double bond is located under the ring, are energetically less favorable because of steric interactions. The additional ring substituent now 
leads to a similar effect in structures $D$ and $C$, where the alkene is oriented toward the methyl group. Only structures $A$ and $F$ remain to contribute significantly to product formation. In addition reactions to terminally substituted alkenes with $X=\mathrm{Me}$, additional steric interactions have to be considered. Table $\mathrm{V}$ clearly showed, that the energy of transition structures is raised considerably, when a methyl group is positioned directly under the ring. In Figure 6, this is the case in structures $A$ and $D$. Additionally, structures B and $\mathrm{F}$ are hampered by a similar effect, since now the alkene methyl group is located next to the ring methyl group. Overall, there are no axial transition structures without considerable repulsive interactions. Consequently, only equatorial addition product is isolated, which consists of two diastereomers in a 1:1 ratio differing in their relative stereochemistry at the newly formed tertiary center.

It was expected from the stereochemical outcome of the carbohydrate radical reactions ${ }^{4}$ that axial substitution adjacent to the radical center should increase axial attack. This is indeed found for reactions of trans-4-tert-butyl-2-methylcyclohexyl radical (17). The reason is a nonbonding interaction of the approaching alkene with the ring methyl group equivalent to 1,3-diaxial interactions for axial transition states.

$\boldsymbol{\gamma}$-Substitution at the Radical. As was shown in Table II, equatorial substitution by $\gamma$-alkyl groups at the radical has no effect on the stereoselectivity. This is in contrast to axial substitution at the same carbon atom, which leads, as predicted by the force field, to the largest effects encountered so far. Again the MM2 model offers a rationalization for this result, which concentrates on the axial transition state conformers. In the case of the crotononitrile addition to 4-tert-butylcyclohexyl radical (14) (Figure 5), a methyl group positioned under the cyclohexyl ring increases the energy relative to the other conformers by more than $3.0 \mathrm{kcal} / \mathrm{mol}$. That axial product is formed at all is due to other transition-state conformations that do not have substituents located under the ring. In the case of the trans-10-methyldecalin-2-yl radical (19), the methyl group is fixed at the bottom side of the ring, and consequently the energy of all axial transition states is increased considerably.

$\delta$-Substitution at the Radical. The effect of equatorial substitution at the ring carbon atom $\delta$ to the radical center has been included in the experimental results presented so far, since most systems utilized substituents in this position to differentiate between equatorial and axial addition products and to anchor other ring substituents into fixed positions. Substitution of the axial position at the $\delta$ carbon atom leads to a small but significant increase of axial addition product for both alkenes in Table II. The MM2 force field indicates a flattening of the cyclohexyl ring, which should decrease the magnitude of 1,3-diaxial interactions and therefore increase axial addition. This effect has been found for nucleophilic additions to cyclohexanones as well, and an equivalent argument has been offered. ${ }^{1}$

Stereoselectivity in Abstraction Reactions. Product ratios for abstraction reactions of substituted cyclohexyl radicals from tri- $n$-butyltin deuteride, bromotrichloromethane, and tetrachloromethane are given in Table III. On comparison with the results for the addition reactions in Tables II and I, a general trend to increased axial attack can be found, where chlorine abstraction shows the highest axial selectivity. Since torsional effects do not change considerably with the change of reagent, an explanation for the increased axial product formation has to be found in the change of 1,3-diaxial interaction. It seems therefore that the replacement of the CHR-terminus of the alkene against a smaller hydrogen atom or a halogen atom at larger distance leads to a decrease in 1,3-diaxial interaction.

\section{Experimental Section}

General. Gas chromatographic measurements were performed on a Carlo Erba 6000 with flame ionization detector coupled to a Shimadzu C-R $4 \mathrm{~A}$ integrator (conditions: $25 \mathrm{~m} \mathrm{OV}-01,70-150^{\circ} \mathrm{C}$ at $7^{\circ} \mathrm{C} / \mathrm{min}$, $150^{\circ} \mathrm{C}$ to $300^{\circ} \mathrm{C}$ at $\left.35^{\circ} \mathrm{C} / \mathrm{min}\right)$. GC/MS data were aquired on a Hewlett-Packard 5790A gas chromatograph coupled to a HewlettPackard 5970A mass selective detector (conditions: $25 \mathrm{~m} \mathrm{SE}-30,70-260$ ${ }^{\circ} \mathrm{C}$ at $12{ }^{\circ} \mathrm{C} / \mathrm{min}$ ). ${ }^{1} \mathrm{H}$ and ${ }^{13} \mathrm{C}$ NMR were recorded on a Varian Gemini
300 or a Varian VXR 400 (TMS as internal standard). Mass spectra were acquired on either a VG 70-250 or a Varian MAT 212. Chromatography utilized silica gel C $560 \mathrm{KV}$ 35-70 mm, Chemische Fabrik Uetikon or aluminum oxide 507C neutral, activity I acc. to Brockmann, Fluka. Melting points are uncorrected.

Benzene and toluene were distilled from calcium hydride and stored over molecular sieves. All reactions were carried out under anhydrous conditions and in a nitrogen atmosphere unless noted otherwise.

4-tert-Butylcyclohexylmercury bromide, ${ }^{7} 4$-tert-butylcyclohexyl iodide, ${ }^{5}$ 3-tert-butylcyclohexanol, ${ }^{13}$ and 4-tert-butylcyclohexyl bromide ${ }^{6}$ were prepared according to literature procedures.

Preparation of Radical Precursors. 4-tert-Butyl-1-methylcyclohexyl Bromide (2). In a $150-\mathrm{mL}$ three-necked flask is placed $6.19 \mathrm{~g}(36.4$ $\mathrm{mmol}$ ) of 4-tert-butyl-1-methylcyclohexanol (1) ${ }^{8}$ After the flask is purged with nitrogen, a stream of $\mathrm{HBr} /$ gas is introduced until the white crystalline alcohol has liquified to a brown oil. The flask is evacuated and purged with nitrogen several times to remove all remaining $\mathrm{HBr}$ gas. The residue is dissolved in $100 \mathrm{~mL}$ of ether, washed with dilute bicarbonate solution and with brine, and dried over anhydrous $\mathrm{MgSO}_{4}$. After evaporation of the solvent, the residue is purified by distillation (Kugelrohr). This yields $7.1 \mathrm{~g}(84 \%)$ of 4-tert-butyl-1-methylcyclohexyl bromide as a mixture of the 4-cis and 4-trans isomers in a 83:17 ratio. ${ }^{1} \mathrm{H}$ NMR $\left(300 \mathrm{MHz}, \mathrm{CDCl}_{3}\right)$ : cis isomer $\delta 0.89\left(\mathrm{~s}, 9 \mathrm{H}, \mathrm{C}\left(\mathrm{CH}_{3}\right)_{3}\right)$, 0.9-1.02( $\mathrm{m}, 1 \mathrm{H}), 1.30-1.43(\mathrm{~m}, 2 \mathrm{H}), 1.47-1.72(\mathrm{~m}, 4 \mathrm{H}), 1.83(\mathrm{~s}, 3$ $\left.\mathrm{H}, \mathrm{C} \cdot 1-\mathrm{CH}_{3}\right), 2.08-2.18(\mathrm{~m}, 2 \mathrm{H})$; trans isomer $\delta 0.84\left(\mathrm{~s}, 9 \mathrm{H}, \mathrm{C}\left(\mathrm{CH}_{3}\right)_{3}\right)$, $1.04-1.29(\mathrm{~m}, 4 \mathrm{H}), 1.47-1.72(\mathrm{~m}, 4 \mathrm{H}), 1.81\left(\mathrm{~s}, 3 \mathrm{H}, \mathrm{C}-1-\mathrm{CH}_{3}\right)$, 2.18-2.32 (m, $2 \mathrm{H})$. ${ }^{13} \mathrm{C}$ NMR $\left(75.5 \mathrm{MHz}^{\mathrm{C}} \mathrm{CDCl}_{3}\right)$ : cis isomer $\delta 71.97$ (C-1), $\left.47.17(\mathrm{C}-4), 43.24(\mathrm{C}-2), 35.82\left(\mathrm{C}-1-\mathrm{CH}_{3}\right), 32.33\left(\mathrm{C}_{(\mathrm{CH}}\right)_{3}\right)$, $\left.27.53\left(\mathrm{C}_{(\mathrm{CH}}\right)_{3}\right), 24.12(\mathrm{C}-3)$; trans isomer $867.35(\mathrm{C}-1), 47.17(\mathrm{C}-4)$, 44.68 (C-2), $29.04\left(\mathrm{C}-1-\mathrm{CH}_{3}\right), 32.33\left(\mathrm{C}\left(\mathrm{CH}_{3}\right)_{3}\right), 27.48\left(\mathrm{C}_{\left.\left(\mathrm{CH}_{3}\right)_{3}\right), 25.48}\right.$ (C-3). MS (EI): $152\left(\mathrm{M}^{+}-\mathrm{HBr}, 16 \%\right), 95\left(\mathrm{M}^{+}-\mathrm{HBr}-t\right.$-Bu, 68\%), $57(t-\mathrm{Bu}, 100 \%)$. Anal. Calcd for $\mathrm{C}_{11} \mathrm{H}_{21} \mathrm{Br}$ : $\mathrm{C}, 56.63 ; \mathrm{H}, 9.07$. Found: C, $56.59 ; \mathrm{H}, 9.20$.

4-tert-Butyl-2-methylcyclohexanol. 4-tert-Butyl-2-methylphenol. To a mixture of $540 \mathrm{~g}(5.0 \mathrm{~mol})$ of $o$-cresol and $13.3 \mathrm{~g}(100 \mathrm{mmol})$ of anhydrous $\mathrm{AlCl}_{3}$ are added dropwise under stirring and cooling $185 \mathrm{~g}$ (2.0 mol) of tert-butyl chloride, keeping the temperature below $20^{\circ} \mathrm{C}$. Stirring is continued for $12 \mathrm{~h}$. The reaction mixture is poured onto an equal volume of crushed ice, and the organic phase is separated and washed with water and $2 \mathrm{~N} \mathrm{Na}_{2} \mathrm{CO}_{3}$ solution and again with water. After drying over anhydrous $\mathrm{MgSO}_{4}$, excess 0 -cresol is distilled off by using a $20-\mathrm{cm}$ Vigreux column. Further vacuum distillation $\left(125^{\circ} \mathrm{C} / 15\right.$ Torr) yields $246 \mathrm{~g}$ ( $75 \%$ ) of 4-tert-butyl-2-methylphenol.

4-tert-Butyl-2-methylcyclohexanol. In a 2-I autoclave are placed 329 $\mathrm{g}$ (2.0 mol) of 4-tert-butyl-2-methylphenol, $20.0 \mathrm{~g}$ of freshly prepared Raney nickel, and $500 \mathrm{~mL}$ of ethanol and this solution is reduced for 12 $\mathrm{h}$ at $100^{\circ} \mathrm{C}$ under a hydrogen pressure of $100 \mathrm{bar}$. After filtering off the catalyst and removing the solvent, $340 \mathrm{~g}(100 \%)$ of a mixture of the four diastereomeric 4-tert-butyl-2-methylcyclohexanols $4 \mathrm{a}-7 \mathrm{a}$ is obtained. From this mixture cis-4-tert-butyl-cis-2-methylcyclohexanol (6a) can be separated by column chromatography on alumina by using pentane:ethyl acetate $(9: 1)$. The remaining three isomers are separated by MPLC chromatography on silica gel with hexane:ethyl acetate $(5: 1)$ as eluent.

[I(cis-4'-tert -Butyl-cis / trans - $2^{\prime}$-methylcyclohexyl)oxy]thiocarbonylimidazole (6b and $7 \mathrm{~b})$. In $10 \mathrm{~mL}$ of dry THF are dissolved $820 \mathrm{mg}(4.81$ mmol) of a mixture of cis-4-tert-butyl-cis-2-methylcyclohexanol (6a) and cis-4-tert-butyl-trans-2-methylcyclohexanol (7a) and $2.0 \mathrm{~g}(11.0 \mathrm{mmol})$ of $N, N^{\prime}$-thiocarbonyldiimidazole. After heating to reflux for $6 \mathrm{~h}$, the solvent is evaporated and the residue is dissolved in $\mathrm{CH}_{2} \mathrm{Cl}_{2}(100 \mathrm{~mL})$. The solution is washed with $50 \mathrm{~mL}$ of water, $0.25 \mathrm{~N} \mathrm{HCl}$, dilute $\mathrm{NaH}$ $\mathrm{CO}_{3}$ solution, and water again and dried over anhydrous $\mathrm{MgSO}_{4}$. After evaporation of the solvent, chromatography on silica gel with pentane: ether (1:1) and Kugelrohr distillation $\left(230^{\circ} \mathrm{C} / 0.05 \mathrm{mbar}\right)$ give $910 \mathrm{mg}$ (68\%) of [[(cis-4'-tert-butyl-cis/trans-2'-methylcyclohexyl)oxy] thiocarbonyl]imidazole as a pale yellow oil. The mixture can readily be separated on a MPLC silica gel column with hexane:ethyl acetate (5:1) as eluent to yield the [[(cis-4'-tert-butyl-cis-2'-methylcyclohexyl)oxy]thiocarbonyl]imidazole (6b) and [[(cis-4'-tert-butyl-trans-2'-methylcyclohexyl)oxy] thiocarbonyl]imidazole (7b) diastereomers. ' $\mathrm{H}$ NMR $\left(300 \mathrm{MHz}, \mathrm{CDCl}_{3}\right):$ b $\delta 0.90\left(\mathrm{~s}, 9 \mathrm{H}, \mathrm{C}\left(\mathrm{CH}_{3}\right)_{3}\right), 0.99(\mathrm{~d}, 3 \mathrm{H}, J=6.9$ $\left.\mathrm{Hz}, \mathrm{C}-2^{\prime}-\mathrm{CH}_{3}\right), 1.08-1.32(\mathrm{~m}, 3 \mathrm{H}), 1.49-1.91(\mathrm{~m}, 4 \mathrm{H}), 2.26-2.35(\mathrm{~m}$, $1 \mathrm{H}), 5.67(\mathrm{~m}, 1 \mathrm{H}, \mathrm{COH}), 7.05+7.63+8.34\left(3^{*} \mathrm{~s}, 3^{*} 1 \mathrm{H}\right.$, imidazole); 7b $\delta 0.89\left(\mathrm{~s}, 9 \mathrm{H}, \mathrm{C}\left(\mathrm{CH}_{3}\right)_{3}\right), 1.10\left(\mathrm{~d}, 3 \mathrm{H}, J=7.5 \mathrm{~Hz}, \mathrm{C}-2^{\prime}-\mathrm{CH}_{3}\right)$, $1.15-1.90(\mathrm{~m}, 6 \mathrm{H}), 2.0-2.1(\mathrm{~m}, 1 \mathrm{H}), 2.35(\mathrm{~m}, 1 \mathrm{H}), 5.47(\mathrm{~m}, 1 \mathrm{H}$, $\mathrm{COH}), 7.06+7.66+8.37\left(3^{*} \mathrm{~s}, 3^{*} 1 \mathrm{H}\right.$, imidazole $) .{ }^{13} \mathrm{C}$ NMR $(75.5$ $\left.\mathrm{MHz}, \mathrm{CDCl}_{3}\right):$ 6b $\delta 183.75(\mathrm{C}=\mathrm{S}), 136.46+130.69+117.65$ (imidazole), $83.88\left(\mathrm{C}-1^{\prime}\right), 47.08\left(\mathrm{C}-4^{\prime}\right), 36.02\left(\mathrm{C}-2^{\prime}\right), 32.37\left(\mathrm{C}^{\prime}\left(\mathrm{CH}_{3}\right)_{3}\right), 30.76$ $+29.67\left(\mathrm{C}-3^{\prime}+\mathrm{C}-6^{\prime}\right), 27.36\left(\mathrm{C}\left(\mathrm{CH}_{3}\right)_{3}\right), 21.23\left(\mathrm{C}-5^{\prime}\right), 18.51\left(\mathrm{C}-2^{\prime}-\right.$ $\left.\mathrm{CH}_{3}\right) ; 7 \mathrm{~b} \delta 183.52(\mathrm{C}=\mathrm{S}), 136.79+130.88+117.91$ (imidazole), 84.16 $\left(\mathrm{C}-1^{\prime}\right), 39.97\left(\mathrm{C}-4^{\prime}\right), 32.03\left(\mathrm{C}\left(\mathrm{CH}_{3}\right)_{3}\right), 31.55\left(\mathrm{C}-2^{\prime}\right), 27.97\left(\mathrm{C}-3^{\prime}\right), 27.09$ 
$\left(\mathrm{C}\left(\mathrm{CH}_{3}\right)_{3}\right), 24.90\left(\mathrm{C}-6^{\prime}\right), 21.93\left(\mathrm{C}-5^{\prime}\right), 16.40\left(\mathrm{C}-2^{\prime}-\mathrm{CH}_{3}\right)$. Anal. Calcd for $\mathrm{C}_{15} \mathrm{H}_{24} \mathrm{~N}_{2} \mathrm{OS}$ : $\mathrm{C}, 64.28 ; \mathrm{H}, 8.63 ; \mathrm{N}, 10.00$. Found: $\mathrm{C}, 64.12 ; \mathrm{H}$, $8.83 ; \mathrm{N}, 9.90$.

cis-4-tert-Butyl-cis-2-methylcyclohexyl Iodide (6c). A solution of $1.70 \mathrm{~g}(10 \mathrm{mmol})$ of trans-4-tert-butyl-trans-2-methylcyclohexanol $\mathbf{( 4 a )}$ $7.61 \mathrm{~g}$ ( $30 \mathrm{mmol})$ of iodine, $10.5 \mathrm{~g}(40 \mathrm{mmol})$ of triphenylphosphine, and $2.72 \mathrm{~g}(40 \mathrm{mmol})$ of imidazole in anhydrous toluene $(100 \mathrm{~mL})$ is heated to $60^{\circ} \mathrm{C}$ for $4 \mathrm{~h}$. After cooling the mixture is extracted with saturated sodium bicarbonate solution and dried over anhydrous $\mathrm{MgSO}_{4}$. The solvent is evaporated and the residue dissolved in pentane. After filtration of insoluble products the solvent is evaporated again and the residue purified by chromatography on silica gel with pentane as eluent followed by Kugelrohr/distillation $\left(60^{\circ} \mathrm{C} / 0.2 \mathrm{Torr}\right)$. This yields $1.65 \mathrm{~g}(59 \%)$ of cis-4-tert-butyl-cis-2-methylcyclohexyl iodide (6c). ${ }^{1} \mathrm{H}$ NMR (300 $\left.\mathrm{MHz}, \mathrm{CDCl}_{3}\right): 0.52-0.62(\mathrm{~m}, 1 \mathrm{H}, \mathrm{H}-4), 0.88\left(\mathrm{~s}, 9 \mathrm{H}, \mathrm{C}\left(\mathrm{CH}_{3}\right)_{3}\right), 0.91$ $\left(\mathrm{d}, J=6.3 \mathrm{~Hz}, 3 \mathrm{H}, \mathrm{CH}_{3}\right), 0.96-1.24(\mathrm{~m}, 2 \mathrm{H}), 1.39-1.48(\mathrm{~m}, 1 \mathrm{H})$, $1.50-1.67(\mathrm{~m}, 2 \mathrm{H}), 1.77$ (dddd, $J=14.5,12.0,4.6,4.1 \mathrm{~Hz}, 1 \mathrm{H}, \mathrm{H}-6_{\mathrm{ax}}$ ); 2.28 (dddd, $J=14.5,3.0,3.0,3.0 \mathrm{~Hz}, 1 \mathrm{H}, \mathrm{H}-6_{\mathrm{eq}}$ ), 4.67 (br s, $1 \mathrm{H}, \mathrm{H}-1$ ). ${ }^{13} \mathrm{C} \mathrm{NMR}\left(75.5 \mathrm{MHz}, \mathrm{CDCl}_{3}\right): \delta 50.61(\mathrm{C}-4), 47.56(\mathrm{C}-2), 37.13$ (C-6) $\left.32.51\left(\mathrm{C}_{(\mathrm{CH}}\right)_{3}\right), 31.47(\mathrm{C}-3), 28.25\left(\mathrm{C}\left(\mathrm{CH}_{3}\right)_{3}\right), 25.00\left(\mathrm{C}-2-\mathrm{CH}_{3}\right), 22.87$ (C-5).

3-tert-Butylcyclohexyl Iodide (10). A suspension of $8.0 \mathrm{~g}(51.2 \mathrm{mmol})$ of 3-tert-butylcyclohexanol (mixture of the cis/trans isomers), $40.3 \mathrm{~g}$ (153 mmol) of iodine, $53.7 \mathrm{~g}(205 \mathrm{mmol})$ of triphenylphosphine, and 13.9 $\mathrm{g}(205 \mathrm{mmol})$ of imidazole in $1.30 \mathrm{I}$ of anhydrous toluene is heated to $60^{\circ} \mathrm{C}$ for $4 \mathrm{~h}$. After cooling, the mixture is extracted with $800 \mathrm{~mL}$ of saturated sodium bicarbonate solution, then washed with sodium thiosulfate solution, and dried over anhydrous $\mathrm{MgSO}_{4}$. The solvent is evaporated, and the residue is dissolved in pentane. After filtration of insoluble products the solution is evaporated again, and the residue is chromatographed on silica gel with pentane as eluent. This yields 3.74 $\mathrm{g}(27 \%)$ of 3-tert-butylcyclohexyl iodide $(\mathbf{1 0})$ as a mixture of the cis and trans isomers. 'H NMR ( $300 \mathrm{MHz}, \mathrm{CDCl}_{3}$ ): trans isomer $\delta 0.84$ (s, 9 $\left.\mathrm{H}, \mathrm{C}\left(\mathrm{CH}_{3}\right)_{3}\right), 0.76-2.54(\mathrm{~m}, 9 \mathrm{H}), 4.17$ (dddd, $1 \mathrm{H}, J=12.2,4.0 \mathrm{~Hz}$ $\mathrm{CHI})$; cis isomer $\delta 0.84\left(\mathrm{~s}, 9 \mathrm{H}, \mathrm{C}\left(\mathrm{CH}_{3}\right)_{3}\right), 0.76-1.90(\mathrm{~m}, 9 \mathrm{H}), 1.98-2.20$ $(\mathrm{m}, 2 \mathrm{H}), 5.00(\mathrm{~m}, 1 \mathrm{H}, \mathrm{CH}) .{ }^{13} \mathrm{C} \mathrm{NMR}\left(75.5 \mathrm{MHz}, \mathrm{CDCl}_{3}\right)$ : trans isomer $\left.\delta 51.07(\mathrm{C}-3), 42.29(\mathrm{C}-2), 40.71(\mathrm{C}-6), 32.05\left(\mathrm{C} \mathrm{CH}_{3}\right)_{3}\right), 31.66$

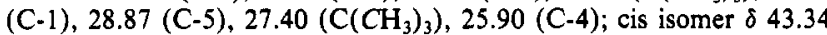
(C-3), $38.39(\mathrm{C}-1), 36.32+37.44(\mathrm{C}-2+\mathrm{C}-6), 32.05\left(\mathrm{C}_{\left.\left(\mathrm{CH}_{3}\right)_{3}\right), 27.48}\right.$ $\left(\mathrm{C}\left(\mathrm{CH}_{3}\right)_{3}\right), 27.01(\mathrm{C}-4), 22.98(\mathrm{C}-5)$.

trans-10-Methyl-2 $\beta$-decalinol (12). In $15 \mathrm{~mL}$ of glacial acetic acid is dissolved $2.23 \mathrm{~g}$ (13.4 mmol) of 10-methyl-trans-decalin-3-one (11), and $2.14 \mathrm{~g}(13.4 \mathrm{mmol})$ of bromine in $5 \mathrm{~mL}$ of glacial acetic acid is added at $0^{\circ} \mathrm{C}$ within $30 \mathrm{~min}$. Stirring is continued for $15 \mathrm{~min}$, and the reaction mixture is poured onto crushed ice. After extraction with $50 \mathrm{~mL}$ of ether, the organic phase is washed with brine and dried over anhydrous $\mathrm{MgSO}_{4}$ After removal of the solvent, the residue is taken up in a mixture of 4 $\mathrm{mL}$ of water, $10 \mathrm{~mL}$ of dioxane, and $10 \mathrm{~mL}$ of methanol. At $0^{\circ} \mathrm{C}$, a solution of $300 \mathrm{mg}(8.0 \mathrm{mmol})$ of $\mathrm{NaBH}_{4}$ in water $(4 \mathrm{~mL})$ is added within $30 \mathrm{~min}$, and stirring is continued for another $30 \mathrm{~min}$. The reaction mixture is poured onto cold $2 \%$ sulfuric acid, saturated with $\mathrm{NaCl}$, and extracted with ether. After drying over anhydrous $\mathrm{MgSO}_{4}$, the solvent is evaporated and the residue dissolved in $100 \mathrm{~mL}$ of dry isopropyl al cohol. After addition of $5.0 \mathrm{~g}$ of $\mathrm{KOH}$ the reaction mixture is heated to $50^{\circ} \mathrm{C}$ for $90 \mathrm{~min}$. The solvent is removed in vacuo, and cold water is added. Extraction with pentane, removal of the solvent and chromatography of the residue with pentane on aluminum oxide (activity III acc. to Brockmann) gives $726 \mathrm{mg}$ (33\%) of $2 \beta, 3 \beta$-oxido-10-methyl-trans-decalin. Reduction of the epoxide with $\mathrm{LiAlH}_{4}$ following a known procedure $^{16}$ gives trans-10-methyl-2 $\beta$-decalinol (12) in $85 \%$ yield. MS (EI): $168\left(\mathrm{M}^{+}, 9 \%\right), 150\left(\mathrm{M}^{+}-\mathrm{H}, \mathrm{O}, 57 \%\right), 135\left(\mathrm{M}^{+}-\mathrm{H}_{2} \mathrm{O}-\mathrm{CH}_{3}, 84 \%\right)$. ${ }^{1} \mathrm{H}$ NMR (300 MHz, $\left.\mathrm{CDCl}_{3}\right): \delta 1.08\left(\mathrm{~s}, 3 \mathrm{H}, \mathrm{C}-10-\mathrm{CH}_{3}\right), 0.95-1.85$ $(\mathrm{m}, 16 \mathrm{H}), 4.13(\mathrm{~m}, 1 \mathrm{H}, \mathrm{CHOH}),{ }^{13} \mathrm{C}$ NMR spectrum identical with published material. ${ }^{26}$

[((10'-Methyl-trans -2' $\beta$-decalinyl)oxy)thiocarbonyl]imidazole (13a). In $50 \mathrm{~mL}$ of THF are dissolved $7.9 \mathrm{~g}$ ( $45 \mathrm{mmol}$ ) of $1,1^{\prime}$-thiocarbonyldiimidazole and $2.5 \mathrm{~g}(14.9 \mathrm{mmol})$ of 10 -methyl-trans-decalin- $2 \beta$-ol (12). The solution is heated to reflux for $6 \mathrm{~h}$. The solvent is evaporated, the residue is taken up in $\mathrm{CH}_{2} \mathrm{Cl}_{2}$, and the solution is washed first with 0.1 N HCL and then with brine. After removal of the solvent, the residue is purified by flash chromatography on silica gel with pentane-ethyl acetate $(5: 1)$ as eluent. Thus, $3.04 \mathrm{~g} \mathrm{(73 \% )}$ of $\left[\left(\left(10^{\prime}\right.\right.\right.$-methyl-trans $-2^{\prime} \beta$ decalinyl)oxy)thiocarbonyl]imidazole (13a) is obtained as a pale yellow oil. ${ }^{1} \mathrm{H}$ NMR $\left(300 \mathrm{MHz}, \mathrm{CDCl}_{3}\right): \delta 1.02\left(\mathrm{~s}, 3 \mathrm{H}, \mathrm{C}-10-\mathrm{CH}_{3}\right), 1.0-1.15$ $(\mathrm{m}, 1 \mathrm{H}), 1.15-1.65(\mathrm{~m}, 10 \mathrm{H}), 1.65-1.85(\mathrm{~m}, 2 \mathrm{H}), 1.90-2.05(\mathrm{~m}, 1 \mathrm{H})$, $2.10-2.25(\mathrm{~m}, 1 \mathrm{H}), 5.80(\mathrm{~m}, 1 \mathrm{H}, \mathrm{CHO}), 7.05+7.68+8.39\left(\mathrm{~s}, 3^{*} 1\right.$ $\mathrm{H}$, imidazole). ${ }^{13} \mathrm{C}$ NMR $\left(75.5 \mathrm{MHz}, \mathrm{CDCl}_{3}\right): \delta 182.8(\mathrm{C}=\mathrm{S}), 136.23$ $+130.09+117.31$ (imidazole), $80.81\left(\mathrm{C}-2^{\prime}\right), 44.53\left(\mathrm{C}-5^{\prime}\right), 43.53\left(\mathrm{C}-1^{\prime}\right)$, $40.55\left(\mathrm{C}-9^{\prime}\right), 32.56\left(\mathrm{C}-10^{\prime}\right), 29.80\left(\mathrm{C}-3^{\prime}\right), 27.75\left(\mathrm{C}-6^{\prime}\right), 26.24\left(\mathrm{C}-7^{\prime}\right)$, $23.89\left(\mathrm{C}-4^{\prime}\right), 20.65\left(\mathrm{C}-8^{\prime}\right), 16.87\left(\mathrm{C}-10^{\prime}-\mathrm{CH}_{3}\right)$. MS (EI): $151\left(\mathrm{M}^{+}-\right.$
$127,33 \%), 150\left(\mathbf{M}^{+}-128,34 \%\right), 95\left(\mathbf{M}^{+}-193,100 \%\right)$. Anal. Calcd for $\mathrm{C}_{14} \mathrm{H}_{22} \mathrm{~N}_{2} \mathrm{OS}$ : C, $64.70 ; \mathrm{H}, 8.00 ; \mathrm{N}, 10.06$. Found: C, $64.50 ; \mathrm{H}$, $8.20 ; \mathrm{N}, 9.81$

Addition Reactions to Alkenes. General Workup Procedures. KF Method. After cooling of the reaction mixture the solvent is evaporated and the residue is taken up in $20 \mathrm{~mL}$ of ether. An excess of potassium fluoride is added together with $2 \mathrm{~mL}$ of water. After it is stirred for 3 $\mathrm{h}$ at room temperature, the mixture is filtered through a pad of anhydrous magnesium sulfate. The solution is evaporated, and the residue purified by chromatography or distillation.

$I_{2} / K F$ Method. After cooling of the reaction mixture, a solution of iodine in pentane is added dropwise until a yellow color remains. The solvent is evaporated and the residue is taken up in $20 \mathrm{~mL}$ of ether. An excess of potassium fluoride is added together with $1 \mathrm{~mL}$ of water. After stirring for 3-6 $\mathrm{h}$ at room temperature, the mixture is filtered through a pad of anhydrous magnesium sulfate. The solution is evaporated and the residue purified by chromatography or distillation.

Determination of Isomer Ratios. Isomer ratios were determined by GC measurements of the reaction mixture. Values reported are mean values over three measurements. A minimum of two experiments were performed. For the addition of the decalyl radical to acrylonitrile, four experiments under different conditions were performed. The GC selectivities found in these experiments were 97.0:3.0, 96.0:4.0, 97.2:2.8, and $96.4: 3.6$, showing a reasonable reproducibility even at analytically unfavorable isomer ratios. In all cases, normalization factors for different isomers have been assumed to be equal. Determination of isomer ratios by ${ }^{13} \mathrm{C}$ NMR employed inverse-gated measurements on the reaction product after chromatography. Evaluation of the signals of equivalent carbon atoms in both isomers gave ratios with a variation of less than $\pm 5 \%$ (relative). Determination of the stereoselectivity for the addition of the 1-methyl-4-tert-butylcyclohexyl radical to crotonitrile gave the same equatorial:axial ratio of $60: 40$ by $\mathrm{GC}$ and ${ }^{13} \mathrm{C}-\mathrm{NMR}$ measurements. ${ }^{1} \mathrm{H}-\mathrm{NMR}$ spectroscopy has been used to determine isomer ratios for chlorides and bromides. Integration of the signals for hydrogen atoms geminal to the halogen substituents gave isomer ratios within $2 \%$ of the $\mathrm{GC}$ values. In bromine abstraction reactions, $\mathrm{GC}$ analysis of the reaction mixtures showed up to $3 \%$ elimination product not detected in the ${ }^{1} \mathrm{H}$ NMR spectra. Typical examples for the determination of isomer stereochemistry as well as examples for ${ }^{1} \mathrm{H}$ - and inverse-gated ${ }^{13} \mathrm{C}-\mathrm{NMR}$ determination of isomer ratios have been included in the supplementary material.

2-(4'-tert-Butyl-1'-cyclohexyl)ethyl Acetate. To a solution of $1.10 \mathrm{~g}$ $(5.0 \mathrm{mmol})$ of 4-tert-butylcyclohexyl bromide and $1.76 \mathrm{~g}(20.5 \mathrm{mmol})$ of vinyl acetate in $20 \mathrm{~mL}$ of dry benzene are added in $10 \mathrm{~h}$ at reflux under nitrogen $2.70 \mathrm{~g}(9.3 \mathrm{mmol})$ of tri-n-butyltin hydride and $32 \mathrm{mg}(0.2$ $\mathrm{mmol}$ ) of AIBN in benzene ( $5 \mathrm{~mL}$ ). Stirring is continued for $1 \mathrm{~h}$ and the reaction mixture worked up according to the $I_{2} / K F$ method. The residue is purified by chromatography on silica gel with pentane:ethyl acetate (38:1) to yield $280 \mathrm{mg}(1.24 \mathrm{mmol}, 25 \%)$ of $2-\left(4^{\prime}\right.$-tert-butyl-1'. cyclohexyl)ethyl acetate as a mixture of the cis and trans isomers in a 49:51 ratio (by inverse-gated ${ }^{13} \mathrm{C}$ NMR). MS and ${ }^{1} \mathrm{H}$ - and ${ }^{13} \mathrm{C}-\mathrm{NMR}$ data are identical with those published by Ohloff et al. ${ }^{19}$

3-(4'-tert-Butylcyclohexyl)-2-ethoxypropionitrile. To a solution of 442 $\mathrm{mg}(2.0 \mathrm{mmol})$ of 4 -tert-butylcyclohexyl bromide and $773 \mathrm{mg}(8.0 \mathrm{mmol})$ of $\alpha$-ethoxyacrylonitrile in $20 \mathrm{~mL}$ of benzene are added in $2 \mathrm{~h}$ at $80^{\circ} \mathrm{C}$ under nitrogen $1.7 \mathrm{~g}(6.0 \mathrm{mmol})$ of tri- $n$-butyltin hydride and $56 \mathrm{mg}(0.34$ $\mathrm{mmol}$ ) of AIBN in benzene ( $6 \mathrm{~mL})$. Stirring is continued under reflux for two more hours, and the reaction mixture is worked up according to the $\mathrm{I}_{2} / \mathrm{KF}$ procedure. Chromatography of the residue on silica gel with pentane-ethyl acetate $(19: 1)$ yields $157 \mathrm{mg}(0.66 \mathrm{mmol}, 33 \%)$ of $3-\left(4^{\prime}-\right.$ tert-butylcyclohexyl)-2-ethoxypropionitrile as a 47.53 mixture of the cis and trans isomers (according to inverse-gated ${ }^{13} \mathrm{C}$ NMR). ${ }^{1} \mathrm{H}$ NMR $\left(300 \mathrm{MHz}, \mathrm{CDCl}_{3}\right)$ : cis isomer $\delta 0.82\left(\mathrm{~s}, 9 \mathrm{H}, \mathrm{C}\left(\mathrm{CH}_{3}\right)_{3}\right), 0.82-1.90(\mathrm{~m}$, $12 \mathrm{H}), 1.24(\mathrm{~m}, 3 \mathrm{H}), 3.42-3.53\left(\mathrm{~m}, 2 \mathrm{H}, \mathrm{CH}_{3} \mathrm{CH}_{2} \mathrm{O}\right), 4.06-4.12(\mathrm{~m}, 1$ $\mathrm{H}, \mathrm{CHCN})$; trans isomer $\delta 0.82\left(\mathrm{~s}, 9 \mathrm{H}, \mathrm{C}\left(\mathrm{CH}_{3}\right)_{3}\right), 0.82-1.90(\mathrm{~m}, 12 \mathrm{H})$, $1.24(\mathrm{~m}, 3 \mathrm{H}), 3.75-3.85\left(\mathrm{~m}, 2 \mathrm{H}, \mathrm{CH}_{3} \mathrm{CH}_{2} \mathrm{O}\right), 4.13-4.18(\mathrm{~m}, 1 \mathrm{H}$, $\mathrm{CHCN}) .{ }^{13} \mathrm{C}$ NMR $\left(75.5 \mathrm{MHz}, \mathrm{CDCl}_{3}\right)$ : cis isomer $\delta 119.03(\mathrm{CN})$, 68.08 (C-2), $65.95\left(\mathrm{OCH}_{2} \mathrm{CH}_{3}\right), 48.10\left(\mathrm{C}-4^{\prime}\right), 35.32(\mathrm{C}-3), 32.36(\mathrm{C}-$ $\left.\left(\mathrm{CH}_{3}\right)_{3}\right), 30.84+30.40\left(\mathrm{C}-2^{\prime}\right), 28.52\left(\mathrm{C}-1^{\prime}\right), 27.19\left(\mathrm{C}\left(\mathrm{CH}_{3}\right)_{3}\right), 21.52$ $\left(\mathrm{C}-3^{\prime}\right), 14.83\left(\mathrm{OCH}_{2} \mathrm{CH}_{3}\right)$; trans isomer $\delta 119.03(\mathrm{CN}), 67.23(\mathrm{C}-2)$, $66.01\left(\mathrm{OCH}_{2} \mathrm{CH}_{3}\right), 48.44\left(\mathrm{C}-4^{\prime}\right), 41.11(\mathrm{C}-3), 33.98\left(\mathrm{C}-1^{\prime}\right), 33.58+$

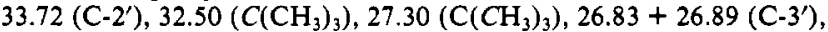
$14.83\left(\mathrm{OCH}_{2} \mathrm{CH}_{3}\right)$. High-resolution MS calcd for $\mathrm{C}_{14} \mathrm{H}_{24} \mathrm{NO}$ : 222.1858 . Found: $222.1859\left(\mathbf{M}^{+}-\mathrm{CH}_{3}, 1 \%\right), 193\left(\mathbf{M}^{+}-44,10 \%\right), 155\left(\mathbf{M}^{+}-82\right.$, $10 \%), 57(t-\mathrm{Bu}, 100 \%)$

3-(4'-tert-Butylcyclohexyl)propionitrile. A solution of $266 \mathrm{mg}(1.00$ $\mathrm{mmol})$ of 4-tert-butylcyclohexyl iodide and $530 \mathrm{mg}(10 \mathrm{mmol})$ of acrylonitrile in $10 \mathrm{~mL}$ of anhydrous toluene is heated to reflux under a nitrogen atmosphere. Then a solution of $380 \mathrm{mg}(1.3 \mathrm{mmol})$ tri- $n$-butyltin hydride and of $20 \mathrm{mg}(0.12 \mathrm{mmol})$ of AIBN in toluene $(2 \mathrm{~mL})$ is 
added in portions within $90 \mathrm{~min}$. After KF workup the residue is subjected to column chromatography using silica gel and pentane-ether $(9: 1)$ as eluent, which yields $155 \mathrm{mg}(80 \%)$ of 3-(4'-tert-butylcyclohexyl)propionitrile as a mixture of two isomers. The inverse-gated ${ }^{13} \mathrm{C}-\mathrm{NMR}$ spectrum of this mixture reveals a trans:cis ratio of 55:45. ${ }^{1} \mathrm{H}$ NMR (300 $\left.\mathrm{MHz}, \mathrm{CDCl}_{3}\right)$ : trans isomer $\delta 0.83\left(\mathrm{~s}, 9 \mathrm{H}, \mathrm{C}\left(\mathrm{CH}_{3}\right)_{3}\right), 0.82-1.19(\mathrm{~m}, 3$ $\mathrm{H}), 1.20-1.87(\mathrm{~m}, 9 \mathrm{H}), 2.30-2.39\left(\mathrm{~m}, 2 \mathrm{H}, \mathrm{CH}_{2} \mathrm{CN}\right)$; cis isomer $\delta 0.83$ (s, $\left.9 \mathrm{H}, \mathrm{C}\left(\mathrm{CH}_{3}\right)_{3}\right), 0.82-1.19(\mathrm{~m}, 3 \mathrm{H}), 1.20-1.87(\mathrm{~m}, 9 \mathrm{H}), 2.30-2.39$ (m, $2 \mathrm{H}, \mathrm{CH}_{2} \mathrm{CN}$ ). ${ }^{13} \mathrm{C}$ NMR (75.5 $\left.\mathrm{MHz}, \mathrm{CDCl}_{3}\right)$ : trans isomer $\delta$ I19.96 (CN), $\left.48.18\left(\mathrm{C}-4^{\prime}\right), 36.88\left(\mathrm{C}-1^{\prime}\right), 33.09\left(\mathrm{C}-2^{\prime}\right), 32.65\left(\mathrm{C}^{2} \mathrm{CH}_{3}\right)_{3}\right)$, $27.57\left(\mathrm{C}\left(\mathrm{CH}_{3}\right)_{3}\right), 27.08\left(\mathrm{C}-3^{\prime}\right), 26.85(\mathrm{C}-3), 14.80(\mathrm{C}-2)$; cis isomer $\delta$

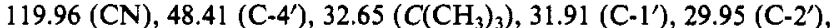

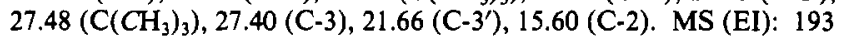
$\left(\mathrm{M}^{+}\right), 178\left(\mathbf{M}^{+}-\mathrm{Me}\right), 138$. Anal. Calcd for $\mathrm{C}_{13} \mathrm{H}_{23} \mathrm{~N}$ : $\mathrm{C}, 80.76 ; \mathrm{H}$, $11.99 ; \mathrm{N}, 7.25$. Found: C, 80.73; H, 12.12; N, 7.02.

2-(4'-tert -Butylcyclohexyl) butyrodinitrile [2-(4'-tert -butylcyclohexyl)succinonitrile]. A solution of $266 \mathrm{mg}(1.00 \mathrm{mmol})$ of $4-t e r t$-butyl-1-iodocyclohexane and of $234 \mathrm{mg}(3.0 \mathrm{mmol})$ of fumaronitrile in anhydrous toluene $(20 \mathrm{~mL})$ is heated to reflux under nitrogen. A solution of $380 \mathrm{mg}(1.3 \mathrm{mmol})$ of tri-n-butyltin hydride and $20 \mathrm{mg}(0.12 \mathrm{mmol})$ of AIBN in toluene $(8 \mathrm{~mL})$ is then added in $80 \mathrm{~min}$ with a syringe pump. After KF workup low-boiling products are removed by Kugelrohr distillation at $60^{\circ} \mathrm{C} / 0.3$ Torr. The solid residue is further purified by flash chromatography on silica gel with hexane-ethyl acetate (8:2) to yield 209 mg (96\%) of cis,trans-2-(4'-tert-butylcyclohexyl)butyrodinitrile. The cis:trans ratio was determined as 40:60 by inverse-gated ${ }^{13} \mathrm{C} \mathrm{NMR} .{ }^{1} \mathrm{H}$ NMR $\left(300 \mathrm{MHz}, \mathrm{CDCl}_{3}\right)$ : trans isomer $\delta 0.85\left(\mathrm{~s}, 9 \mathrm{H}, \mathrm{C}\left(\mathrm{CH}_{3}\right)_{3}\right)$, 0.89-1.43 (m, $5 \mathrm{H}), 1.47-1.76(\mathrm{~m}, 2 \mathrm{H}), 1.79-2.19(\mathrm{~m}, 3 \mathrm{H}), 2.62-2.85$ $\left(\mathrm{m}, 2 \mathrm{H}, \mathrm{CH}_{2} \mathrm{CN}\right), 2.88-3.25(\mathrm{~m}, 1 \mathrm{H}, \mathrm{CHCN})$; cis isomer $\delta 0.85(\mathrm{~s}, 9$ $\left.\mathrm{H}, \mathrm{C}\left(\mathrm{CH}_{3}\right)_{3}\right), 0.89-1.43(\mathrm{~m}, 5 \mathrm{H}), 1.47-1.76(\mathrm{~m}, 2 \mathrm{H}), 1.79-2.19(\mathrm{~m}$, $3 \mathrm{H}), 2.62-2.85\left(\mathrm{~m}, 2 \mathrm{H}, \mathrm{CH}_{2} \mathrm{CN}\right), 2.88-3.25(\mathrm{~m}, 1 \mathrm{H}, \mathrm{CHCN}) .{ }^{13} \mathrm{C}$ NMR (75.5 MHz, CDCl $\left.{ }_{3}\right)$ : trans isomer $\delta 118.15+115.88(\mathrm{C}-1-\mathrm{N}+$ C-4-N), $47.48\left(\mathrm{C}^{\prime} 4^{\prime}\right), 38.61\left(\mathrm{C}-1^{\prime}\right), 34.61(\mathrm{C}-3), 32.38\left(\mathrm{C}^{-}\left(\mathrm{CH}_{3}\right)_{3}\right), 31.36$ $+29.24\left(\mathrm{C}-2^{\prime}\right), 27.47\left(\mathrm{C}\left(\mathrm{CH}_{3}\right)_{3}\right), 26.66+26.46\left(\mathrm{C}-3^{\prime}\right), 18.87(\mathrm{C}-2)$; cis isomer $\delta 118.15+115.88(\mathrm{C}-1-\mathrm{N}+\mathrm{C}-4-\mathrm{N}), 47.70\left(\mathrm{C}-4^{\prime}\right), 34.54(\mathrm{C}-3)$,

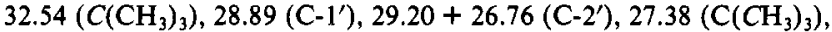
$21.16+26.76\left(\mathrm{C}-3^{\prime}\right), 19.47(\mathrm{C}-2)$. MS (EI): $218\left(\mathrm{M}^{+}\right), 203\left(\mathrm{M}^{+}\right.$ Me), 163. Anal. Calcd for $\mathrm{C}_{14} \mathrm{H}_{22} \mathrm{~N}_{2}: \mathrm{C}, 77.01 ; \mathrm{H}, 10.16 ; \mathrm{N}, 12.83$. Found: C, 77.06; H, 10.22; N, 12.69 .

3-(4'-tert-Butylcyclohexyl) butyronitrile. A solution of $266 \mathrm{mg}(1.00$ $\mathrm{mmol})$ of 4-tert-butyl-1-iodocyclohexane and $670 \mathrm{mg}(10 \mathrm{mmol})$ of crotononitrile in anhydrous toluene $(20 \mathrm{~mL})$ is heated to reflux under nitrogen. A solution of $300 \mathrm{mg}(1.1 \mathrm{mmol})$ of tri- $n$-butyltin hydride and $16 \mathrm{mg}(0.1 \mathrm{mmol})$ AIBN in toluene $(2 \mathrm{~mL})$ is then added within $100 \mathrm{~min}$ by syringe pump. After KF workup low-boiling products are removed by Kugelrohr distillation $\left(100^{\circ} \mathrm{C} / 15\right.$ Torr $)$. The residue is further distilled $\left(100^{\circ} \mathrm{C} / 0.1\right.$ Torr) to yield $185 \mathrm{mg}(77 \%)$ of cis,trans-3-(4'tert-butylcyclohexyl)butyronitrile. The trans:cis ratio was determined as 74:26 by inverse-gated ${ }^{13} \mathrm{C} \mathrm{NMR}$. 'H NMR $\left(300 \mathrm{MHz}, \mathrm{CDCl}_{3}\right)$ : trans isomer $\delta 0.84\left(\mathrm{~s}, 9 \mathrm{H}, \mathrm{C}\left(\mathrm{CH}_{3}\right)_{3}\right), 0.90-1.03(\mathrm{~m}, 3 \mathrm{H}), 1.04(\mathrm{~d}, J=7.0$ $\left.\mathrm{Hz}, 3 \mathrm{H}, \mathrm{C}-4-H_{3}\right), 1.19-2.09(\mathrm{~m}, 8 \mathrm{H}), 2.25$ (dd, $J=16.4,7.4 \mathrm{~Hz}, 1 \mathrm{H}$, $\mathrm{CH}_{2} \mathrm{CN}$ ), 2.36 (dd, $J=16.4,5.6 \mathrm{~Hz}, 1 \mathrm{H}, \mathrm{CH}_{2} \mathrm{CN}$ ); cis isomer $\delta 0.84$ $\left(\mathrm{s}, 9 \mathrm{H}, \mathrm{C}\left(\mathrm{CH}_{3}\right)_{3}\right), 0.90-1.03(\mathrm{~m}, 3 \mathrm{H}), 1.10(\mathrm{~d}, J=6.8 \mathrm{~Hz}, 3 \mathrm{H}$, C-4- $\left.H_{3}\right), 1.19-2.09(\mathrm{~m}, 8 \mathrm{H}), 2.26$ (dd, $J=16.4,7.4 \mathrm{~Hz}, 1 \mathrm{H}, \mathrm{CH}_{2} \mathrm{CN}$ ) 2.44 (dd, $\left.J=16.4,4.0 \mathrm{~Hz}, 1 \mathrm{H}, \mathrm{CH}_{2} \mathrm{CN}\right) .{ }^{13} \mathrm{C} \mathrm{NMR}(75.5 \mathrm{MHz}$, $\left.\mathrm{CDCl}_{3}\right)$ : trans isomer $\delta 119.32(\mathrm{CN}), 41.81\left(\mathrm{C}-4^{\prime}\right), 35.65(\mathrm{C}-3), 32.40$ $\left(\mathrm{C}\left(\mathrm{CH}_{3}\right)_{3}\right), 30.87+29.48\left(\mathrm{C}-2^{\prime}\right), 27.56\left(\mathrm{C}\left(\mathrm{CH}_{3}\right)_{3}\right), 27.22+27.30(\mathrm{C}-$ $\left.3^{\prime}\right), 22.33(\mathrm{C}-2), 16.70(\mathrm{C}-4)$; cis isomer $\delta 119.10(\mathrm{CN}), 48.20\left(\mathrm{C}-4^{\prime}\right)$,

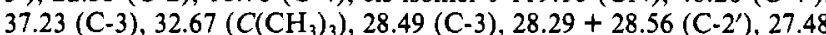
$\left(\mathrm{C}\left(\mathrm{CH}_{3}\right)_{3}\right), 23.04(\mathrm{C}-2), 21.78+21.89\left(\mathrm{C}-3^{\prime}\right), 17.97(\mathrm{C}-4)$. MS (EI): $218\left(\mathrm{M}^{+}\right), 203\left(\mathrm{M}^{+}-\mathrm{Me}\right)$, 163. Anal. Calcd for $\mathrm{C}_{14} \mathrm{H}_{25} \mathrm{~N}: \mathrm{C}, 81.09$ $\mathrm{H}, 12.15 ; \mathrm{N}, 6.75$. Found: $\mathrm{C}, 81.15 ; \mathrm{H}, 12.40 ; \mathrm{N}, 6.42$.

Ethyl 3-(4'-tert -Butylcyclohexyl)-2-(ethoxycarbonyl)propionate. cis4-tert-Butyl-1-cyclohexyl bromide, $658 \mathrm{mg}(3.00 \mathrm{mmol})$, is dissolved in toluene $(20 \mathrm{~mL})$ and heated to $90^{\circ} \mathrm{C}$ under argon. Then a solution of $1.30 \mathrm{~g}(4.5 \mathrm{mmol})$ of tri- $n$-butylstannane and $100 \mathrm{mg}(0.61 \mathrm{mmol})$ of AIBN in toluene $(6 \mathrm{~mL})$ and a second solution of $774 \mathrm{mg}(4.50 \mathrm{mmol})$ methylenemalonic diethyl ester in toluene $(6 \mathrm{~mL})$ is added within 140 min. After KF workup the residue is purified by chromatography on silica gel with pentane-ether $(10: 1)$, which yields $398 \mathrm{mg}(42 \%)$ of ethyl 3-(4'-tert-butylcyclohexyl)-2-(ethoxycarbonyl)propionate as a $44: 56$ mixture of the trans and cis isomers (by GC). ${ }^{1} \mathrm{H}$ NMR $(300 \mathrm{MHz}$, $\left.\mathrm{CDCl}_{3}\right)$ : trans isomer $\delta 0.82\left(\mathrm{~s}, 9 \mathrm{H}, \mathrm{C}\left(\mathrm{CH}_{3}\right)_{3}\right), 0.88-2.00(\mathrm{~m}, 12 \mathrm{H})$, $1.27\left(\mathrm{t}, 6 \mathrm{H}, J=7.1 \mathrm{~Hz}, \mathrm{CO}_{2} \mathrm{CH}_{2} \mathrm{CH}_{3}\right), 3.44(\mathrm{t}, 1 \mathrm{H}, J=7.7 \mathrm{~Hz}$ C-2- $\mathrm{H}), 4.19\left(\mathrm{q}, 4 \mathrm{H}, J=7.1 \mathrm{~Hz}, \mathrm{CO}_{2} \mathrm{CH}_{2} \mathrm{CH}_{3}\right.$ ); cis isomer $\delta 0.83$ (s, $\left.9 \mathrm{H}, \mathrm{C}\left(\mathrm{CH}_{3}\right)_{3}\right), 0.88-2.00(\mathrm{~m}, 12 \mathrm{H}), 1.27(\mathrm{t}, 6 \mathrm{H}, J=7.1 \mathrm{~Hz}$, $\left.\mathrm{CO}_{2} \mathrm{CH}_{2} \mathrm{CH}_{3}\right), 3.35(\mathrm{t}, 1 \mathrm{H}, J=7.6 \mathrm{~Hz}, \mathrm{C}-2-H), 4.19(\mathrm{q}, 4 \mathrm{H}, J=7.1$ $\left.\mathrm{Hz}, \mathrm{CO}_{2} \mathrm{CH}_{2} \mathrm{CH}_{3}\right) .{ }^{13} \mathrm{C} \mathrm{NMR}\left(75.5 \mathrm{MHz}, \mathrm{CDCl}_{3}\right)$ : trans isomer $\delta$ $169.69(\mathrm{C}=\mathrm{O}), 61.21\left(\mathrm{CO}_{2} \mathrm{CH}_{2} \mathrm{CH}_{3}\right), 49.82(\mathrm{C}-2), 48.09\left(\mathrm{C}-4^{\prime}\right), 36.07$

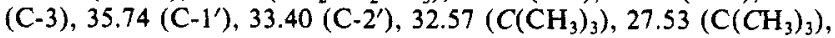

$26.31\left(\mathrm{C}-3^{\prime}\right), 14.10\left(\mathrm{CO}_{2} \mathrm{CH}_{2} \mathrm{CH}_{3}\right)$; cis isomer $\delta 169.69(\mathrm{C}=0), 61.21$ $\left(\mathrm{CO}_{2} \mathrm{CH}_{2} \mathrm{CH}_{3}\right), 50.68(\mathrm{C}-2), 48.50\left(\mathrm{C}-4^{\prime}\right), 32.57\left(\mathrm{C}\left(\mathrm{CH}_{3}\right)_{3}\right), 30.55(\mathrm{C}-$ $\left.1^{\prime}\right), 30.36\left(\mathrm{C}-2^{\prime}\right), 30.12(\mathrm{C}-3), 27.53\left(\mathrm{C}\left(\mathrm{CH}_{3}\right)_{3}\right), 21.61\left(\mathrm{C}-3^{\prime}\right), 14.10$ $\left(\mathrm{CO}_{2} \mathrm{CH}_{2} \mathrm{CH}_{3}\right)$. MS (EI): $312\left(\mathrm{M}^{+}\right), 297\left(\mathrm{M}^{+}-\mathrm{Me}\right), 267$. Anal.

Calcd for $\mathrm{C}_{18} \mathrm{H}_{32} \mathrm{O}_{4}: \mathrm{C}, 69.29 ; \mathrm{H}, 10.32$. Found: $\mathrm{C}, 69.22 ; \mathrm{H}, 10.49$.

Ethyl 3-(4'-tert-Butylcyclohexyl)-2-(ethoxycarbonyl)butyrate. cis-4tert-Butylcyclohexyl bromide, $662 \mathrm{mg}$ ( $3.00 \mathrm{mmol})$, is dissolved in toluene $(20 \mathrm{~mL})$ and heated to $90^{\circ} \mathrm{C}$ under argon. Then a solution of $653 \mathrm{mg}$ $(3.5 \mathrm{mmol})$ of diethyl ethylidenemalonate in toluene $(7 \mathrm{~mL})$ and a second solution of $1.0 \mathrm{~g}(3.5 \mathrm{mmol})$ of tri- $n$-butyltin hydride and $80 \mathrm{mg}(0.49$ mmol) AIBN in toluene $(7 \mathrm{~mL})$ are added simultaneously within $2 \mathrm{~h}$. After KF workup the residue is purified by chromatography on silica gel with pentane-ether (10:1), which yields $209 \mathrm{mg}$ (21\%) of ethyl 3-(4'tert-butylcyclohexyl)-2-(ethoxycarbonyl)butyrate. The trans:cis ratio is determined to be $73: 27$ by GC. ${ }^{1} \mathrm{H}$ NMR $\left(300 \mathrm{MHz}, \mathrm{CDCl}_{3}\right)$ : trans isomer $\delta 0.84\left(\mathrm{~s}, 9 \mathrm{H}, \mathrm{C}\left(\mathrm{CH}_{3}\right)_{3}\right), 0.90\left(\mathrm{~d}, J=6.8 \mathrm{~Hz}, 3 \mathrm{H}, \mathrm{C}-4-\mathrm{H}_{3}\right)$, 0.93-1.90 (m, $12 \mathrm{H}), 1.27\left(\mathrm{t}, 6 \mathrm{H}, J=7.1 \mathrm{~Hz}, \mathrm{CO}_{2} \mathrm{CH}_{2} \mathrm{CH}_{3}\right), 2.17(\mathrm{~m}$, $1 \mathrm{H}), 3.40(\mathrm{~d}, J=9.0 \mathrm{~Hz}, 1 \mathrm{H}, \mathrm{C}-2-\mathrm{H}), 4.18\left(\mathrm{q}, 2 \mathrm{H}, \mathrm{CO}_{2} \mathrm{CH}_{2} \mathrm{CH}_{3}\right)$, $4.19\left(\mathrm{q}, 2 \mathrm{H}, \mathrm{CO}_{2} \mathrm{CH}_{2} \mathrm{CH}_{3}\right)$; cis isomer $\delta 0.84\left(\mathrm{~s}, 9 \mathrm{H}, \mathrm{C}\left(\mathrm{CH}_{3}\right)_{3}\right), 1.06$ $\left(\mathrm{d}, J=6.8 \mathrm{~Hz}, 3 \mathrm{H}, \mathrm{C}-4-\mathrm{H}_{3}\right), 0.93-1.90(\mathrm{~m}, 12 \mathrm{H}), 1.27(\mathrm{t}, 6 \mathrm{H}, J=$ $\left.7.1 \mathrm{~Hz}, \mathrm{CO}_{2} \mathrm{CH}_{2} \mathrm{CH}_{3}\right), 2.39(\mathrm{~m}, 1 \mathrm{H}), 3.57(\mathrm{~d}, J=4.1 \mathrm{~Hz}, 1 \mathrm{H}, \mathrm{C}-2-\mathrm{H})$, 4.19 (q, $\left.2 \mathrm{H}, \mathrm{CO}_{2} \mathrm{CH}_{2} \mathrm{CH}_{3}\right), 4.20\left(\mathrm{q}, 2 \mathrm{H}, \mathrm{CO}_{2} \mathrm{CH}_{2} \mathrm{CH}_{3}\right) .{ }^{13} \mathrm{C} \mathrm{NMR}$ $\left(75.5 \mathrm{MHz}, \mathrm{CDCl}_{3}\right)$ : trans isomer $\delta 169.30+169.03\left(\mathrm{CO}_{2} \mathrm{CH}_{2} \mathrm{CH}_{3}\right)$, $61.33+61.11\left(\mathrm{CO}_{2} \mathrm{CH}_{2} \mathrm{CH}_{3}\right), 55.92(\mathrm{C}-2), 48.17\left(\mathrm{C}-4^{\prime}\right), 40.29\left(\mathrm{C}-1^{\prime}\right)$, $38.31(\mathrm{C}-3), 32.38\left(\mathrm{C}\left(\mathrm{CH}_{3}\right)_{3}\right), 31.78\left(\mathrm{C}-2^{\prime}\right), 27.77+27.26\left(\mathrm{C}-3^{\prime}\right), 27.54$

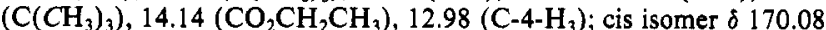
$+168.81\left(\mathrm{CO}_{2} \mathrm{CH}_{2} \mathrm{CH}_{3}\right), 60.69\left(\mathrm{CO}_{2} \mathrm{CH}_{2} \mathrm{CH}_{3}\right), 53.95(\mathrm{C}-2), 48.17(\mathrm{C}-$ $\left.4^{\prime}\right), 35.53\left(\mathrm{C}-1^{\prime}\right), 32.62\left(C\left(\mathrm{CH}_{3}\right)_{3}\right), 31.93(\mathrm{C}-3), 28.10+28.60\left(\mathrm{C}-2^{\prime}\right)$, $27.54\left(\mathrm{C}(\mathrm{CH} 3)_{3}\right), 21.81+21.55\left(\mathrm{C}-3^{\prime}\right), 14.38\left(\mathrm{C}-4-\mathrm{H}_{3}\right), 14.14\left(\mathrm{CO}_{2} \mathrm{C}-\right.$ $\left.\mathrm{H}_{2} \mathrm{CH}_{3}\right)$. MS (EI): $326\left(\mathrm{M}^{+}\right), 311\left(\mathrm{M}^{+}-\mathrm{Me}\right), 281\left(\mathrm{M}^{+}-\mathrm{C}_{2} \mathrm{H}_{5} \mathrm{O}\right)$. Anal. Calcd for $\mathrm{C}_{19} \mathrm{H}_{34} \mathrm{O}_{4}: \mathrm{C}, 69.90 ; \mathrm{H}, 10.50$. Found: $\mathrm{C}, 70.17 ; \mathrm{H}$, 10.72

Methyl 3-(4'-tert-Butylcyclohexyl)-2-(ethoxycarbonyl)-4-methylpentanoate. cis-4-tert-Butylcyclohexyl bromide, $658 \mathrm{mg}(3.00 \mathrm{mmol})$, and dimethyl isobutylidenemalonate, $5.59 \mathrm{~g}(32 \mathrm{mmol})$, are dissolved in toluene $(30 \mathrm{~mL})$ and heated to $90^{\circ} \mathrm{C}$ under argon. Then a solution of $1.0 \mathrm{~g}(3.5 \mathrm{mmol})$ tri- $n$-butyltin hydride and $100 \mathrm{mg}(0.61 \mathrm{mmol})$ of AIBN in toluene $(5 \mathrm{~mL})$ is added within $2 \mathrm{~h}$. After $\mathrm{KF}$ workup the residue is purified by chromatography on silica gel with pentane-ether (10:1), which yields $117 \mathrm{mg}$ (12\%) of methyl 3-(4'-tert-butylcyclohexyl)-2-(ethoxycarbonyl)-4-methylpentanoate. The trans:cis ratio is determined to be $88: 12$ by GC. ${ }^{1} \mathrm{H}$ NMR $\left(300 \mathrm{MHz}, \mathrm{CDCl}_{3}\right)$ : trans isomer $\delta 0.81\left(\mathrm{~s}, 9 \mathrm{H}, \mathrm{C}\left(\mathrm{CH}_{3}\right)_{3}\right), 0.87\left(\mathrm{~d}, J=6.8 \mathrm{~Hz}, 3 \mathrm{H}, \mathrm{CH}\left(\mathrm{CH}_{3}\right)_{2}\right)$, $0.92\left(\mathrm{~d}, J=6.8 \mathrm{~Hz}, 3 \mathrm{H}, \mathrm{CH}\left(\mathrm{CH}_{3}\right)_{2}\right), 0.87-2.08(\mathrm{~m}, 12 \mathrm{H}), 3.58(\mathrm{~d}, J$ $=6.9 \mathrm{~Hz}, 1 \mathrm{H}, \mathrm{C}-2-\mathrm{H}), 3.71\left(\mathrm{q}, 2 \mathrm{H}, \mathrm{CO}_{2} \mathrm{CH}_{3}\right), 3.72\left(\mathrm{q}, 2 \mathrm{H}, \mathrm{CO}_{2} \mathrm{CH}_{3}\right)$; cis isomer $\delta 0.83\left(\mathrm{~s}, 9 \mathrm{H}, \mathrm{C}\left(\mathrm{CH}_{3}\right)_{3}\right), 3.70\left(\mathrm{q}, 2 \mathrm{H}, \mathrm{CO}_{2} \mathrm{CH}_{3}\right), 3.73(\mathrm{q}, 2$ $\left.\mathrm{H}, \mathrm{CO}_{2} \mathrm{CH}_{3}\right) .{ }^{13} \mathrm{C}$ NMR $\left(75.5 \mathrm{MHz}, \mathrm{CDCl}_{3}\right)$ : trans isomer $\delta 170.16$ $+170.07\left(\mathrm{CO}_{2} \mathrm{CH}_{3}\right), 51.97+51.28\left(\mathrm{CO}_{2} \mathrm{CH}_{3}\right), 49.07(\mathrm{C}-2), 47.81(\mathrm{C}-$ $\left.4^{\prime}\right), 38.01\left(\mathrm{C}-1^{\prime}\right), 32.06\left(C\left(\mathrm{CH}_{3}\right)_{3}\right), 31.86+30.71\left(\mathrm{C}-2^{\prime}\right), 27.48\left(\mathrm{C}-3^{\prime}\right)$, $27.24\left(\mathrm{C}\left(\mathrm{CH}_{3}\right)_{3}\right), 20.48\left(\mathrm{CH}\left(\mathrm{CH}_{3}\right)_{2}\right), 19.73\left(\mathrm{CH}\left(\mathrm{CH}_{3}\right)_{2}\right)$; cis isomer $\delta$ $170.07\left(\mathrm{CO}_{2} \mathrm{CH}_{2} \mathrm{CH}_{3}\right), 51.70\left(\mathrm{CO}_{2} \mathrm{CH}_{3}\right), 49.40(\mathrm{C}-2), 47.52\left(\mathrm{C}-4^{\prime}\right)$,

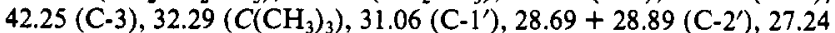
$\left(\mathrm{C}\left(\mathrm{CH}_{3}\right)_{3}\right), 21.57+21.49\left(\mathrm{C}-3^{\prime}\right), 20.61\left(\mathrm{CH}\left(\mathrm{CH}_{3}\right)_{2}\right), 17.66(\mathrm{CH}(\mathrm{C}-$ $\left.\left.\mathrm{H}_{3}\right)_{2}\right)$. MS (EI): $326\left(\mathrm{M}^{+}\right), 311\left(\mathrm{M}^{+}-\mathrm{Me}\right), 295\left(\mathrm{M}^{+}-\mathrm{CH}_{3} \mathrm{O}\right)$. Anal. Calcd for $\mathrm{C}_{21} \mathrm{H}_{38} \mathrm{O}_{4}: C, 71.15 ; \mathrm{H}, 10.80$. Found: $\mathrm{C}, 69.97 ; \mathrm{H}, 10.71$.

3-(4'-tert-Butyl-1'-methylcyclohexyl)propionitrile. 4-tert-Butyl-1methylcyclohexyl bromide, $935 \mathrm{mg}$ ( $4.0 \mathrm{mmol})$, and acrylonitrile, $2.1 \mathrm{~g}$ $(40.0 \mathrm{mmol})$, are dissolved in benzene $(20 \mathrm{~mL})$. After thorough degassing the solution is heated to reflux and a second solution of $1.75 \mathrm{~g}$ $(6.0 \mathrm{mmol})$ tri- $n$-butylstannane and of $46 \mathrm{mg}(0.28 \mathrm{mmol})$ AIBN in benzene $(5 \mathrm{~mL})$ is added within $5 \mathrm{~min}$. Heating is continued for $1 \mathrm{~h}$. After $\mathrm{I}_{2} / \mathrm{KF}$ workup the residue is purified by column chromatography on silica gel with pentane-ethyl acetate $(19: 1)$ as eluent. The cis- and trans $-3-\left(4^{\prime}\right.$-tert-butyl-1'-methylcyclohexyl)propionitriles are isolated in $65 \%$ yield $(541 \mathrm{mg})$ in a $64: 36$ ratio. ${ }^{1} \mathrm{H}$ NMR $\left(300 \mathrm{MHz}, \mathrm{CDCl}_{3}\right)$ : cis isomer $\delta 0.85\left(\mathrm{~s}, 12 \mathrm{H}, \mathrm{C}\left(\mathrm{CH}_{3}\right)_{3}+\mathrm{C}-1^{\prime}-\mathrm{CH}_{3}\right), 0.98-1.22(\mathrm{~m}, 5 \mathrm{H})$, $1.46-1.58(\mathrm{~m}, 4 \mathrm{H}), 1.70\left(\mathrm{t}, 2 \mathrm{H}, J=8.3 \mathrm{~Hz}, \mathrm{CH}_{2} \mathrm{CH}_{2} \mathrm{CN}\right), 2.22(\mathrm{t}, 2$ $\left.\mathrm{H}, J=8.3 \mathrm{~Hz}, \mathrm{CH}_{2} \mathrm{CN}\right)$; trans isomer $\delta 0.85\left(\mathrm{~s}, 9 \mathrm{H}, \mathrm{C}\left(\mathrm{CH}_{3}\right)_{3}\right), 0.87$ (s, $\left.3 \mathrm{H}, \mathrm{C}-1^{\prime}-\mathrm{CH}_{3}\right), 0.95-1.20(\mathrm{~m}, 5 \mathrm{H}), 1.40-1.62(\mathrm{~m}, 4 \mathrm{H}), 1.65(\mathrm{t}$, $\left.2 \mathrm{H}, J=8.2 \mathrm{~Hz}, \mathrm{CH}_{2} \mathrm{CH}_{2} \mathrm{CN}\right), 2.30\left(\mathrm{t}, 2 \mathrm{H}, J=8.2 \mathrm{~Hz}, \mathrm{CH}_{2} \mathrm{CN}\right) .{ }^{13} \mathrm{C}$ NMR $\left(75.5 \mathrm{MHz}, \mathrm{CDCl}_{3}\right)$; cis isomer $\delta 120.83(\mathrm{CN}), 47.73\left(\mathrm{C}-4^{\prime}\right)$, $37.36\left(\mathrm{C}-2^{\prime}\right), 32.11\left(\mathrm{C}\left(\mathrm{CH}_{3}\right)_{3}\right), 31.74\left(\mathrm{C}-1^{\prime}\right), 31.04(\mathrm{C}-3), 28.27\left(\mathrm{C}-1^{\prime}-\right.$ $\left.\mathrm{CH}_{3}\right), 27.28\left(\mathrm{C}\left(\mathrm{CH}_{3}\right)_{3}\right), 22.13\left(\mathrm{C}-3^{\prime}\right), 11.59(\mathrm{C}-2)$; trans isomer $\delta 120.77$ (CN), $48.06\left(\mathrm{C}^{\prime} 4^{\prime}\right), 40.87\left(\mathrm{C}-3^{\prime}\right), 37.25\left(\mathrm{C}-2^{\prime}\right), 32.11\left(\mathrm{C}\left(\mathrm{CH}_{3}\right)_{3}\right), 31.74$ $\left(\mathrm{C}-1^{\prime}\right), 27.25\left(\mathrm{C}\left(\mathrm{CH}_{3}\right) 3\right), 22.27\left(\mathrm{C}-3^{\prime}\right), 20.51\left(\mathrm{C}-1^{\prime}-\mathrm{CH}_{3}\right), 11.40(\mathrm{C}-2)$. MS (EI): $207\left(\mathrm{M}^{+}\right) ; 192\left(\mathrm{M}^{+}-\mathrm{CH}_{3}\right) ; 152\left(\mathrm{M}^{+}-t\right.$-Bu); $57(t$-Bu). Anal. Calcd for $\mathrm{C}_{14} \mathrm{H}_{25} \mathrm{~N}$ : $\mathrm{C}, 81.09 ; \mathrm{H}, 12.15 ; \mathrm{N}, 6.75$. Found: $\mathrm{C}$, $80.90 ; \mathrm{H}, 12.23 ; \mathrm{N}, 6.41$.

3-(4'-tert-Butyl-1'-methylcyclohexyl)butyronitrile. 4-tert-Butyl-1methylcyclohexyl bromide, $700 \mathrm{mg}(3.0 \mathrm{mmol})$, and crotononitrile, 805 
$\mathrm{mg}(12.0 \mathrm{mmol})$, are dissolved in dry benzene $(20 \mathrm{~mL})$. After degassing with dry nitrogen gas the solution is heated to reflux and a solution of $1.31 \mathrm{~g}(4.5 \mathrm{mmol})$ tri- $n$-butylstannane and $35 \mathrm{mg}(0.21 \mathrm{mmol})$ of AIBN in benzene $(5 \mathrm{~mL})$ is added within $20 \mathrm{~h}$ by syringe pump. Heating is continued for $3 \mathrm{~h}$. After $\mathrm{I}_{2} / \mathrm{KF}$ workup the residue is purified by column chromatography on silica gel with pentane-ethyl acetate (19:1) as eluent. This yields $252 \mathrm{mg}(38 \%)$ of a 40:60 mixture of cis- and trans-3-(4'. tert-butyl-cis $11^{\prime}$-methylcyclohexyl)butyronitrile. ${ }^{1} \mathrm{H}$ NMR $(300 \mathrm{MHz}$, $\left.\mathrm{CDCl}_{3}\right)$ : cis isomer $\delta 0.71\left(\mathrm{~s}, 3 \mathrm{H}, \mathrm{C}-1^{\prime}-\mathrm{CH}_{3}\right), 0.85\left(\mathrm{~s}, 9 \mathrm{H}, \mathrm{C}\left(\mathrm{CH}_{3}\right)_{3}\right)$ $1.04\left(\mathrm{~d}, 3 \mathrm{H}, J=6.7 \mathrm{~Hz}, \mathrm{C}-4-H_{3}\right), 0.99-1.16(\mathrm{~m}, 5 \mathrm{H}), 1.45-1.64(\mathrm{~m}$ $4 \mathrm{H}), 2.09\left(\mathrm{~d}, 1 \mathrm{H}, J=16.4 \mathrm{~Hz}, \mathrm{C} H^{\prime} \mathrm{CN}\right), 2.41(\mathrm{dd}, 1 \mathrm{H}, J=16.3,3.4$ $\mathrm{Hz}, \mathrm{CHCN})$; trans isomer $\delta 0.79\left(\mathrm{~s}, 3 \mathrm{H}, \mathrm{C} \cdot \mathrm{l}^{\prime}-\mathrm{CH}_{3}\right), 0.85(\mathrm{~s}, 9 \mathrm{H}$, $\left.\mathrm{C}\left(\mathrm{CH}_{3}\right)_{3}\right), 1.07\left(\mathrm{~d}, 3 \mathrm{H}, J=6.9 \mathrm{~Hz}, \mathrm{C}-4-\mathrm{H}_{3}\right), 0.99-1.16(\mathrm{~m}, 4 \mathrm{H})$, $1.45-1.64(\mathrm{~m}, 6 \mathrm{H}), 2.05(\mathrm{~d}, 1 \mathrm{H}, J=16.5 \mathrm{~Hz}, \mathrm{CHCN}), 2.50(\mathrm{dd}, 1 \mathrm{H}$, $J=16.5 \mathrm{~Hz}, 3.9 \mathrm{~Hz}, \mathrm{CH} H C N) \cdot{ }^{13} \mathrm{C}$ NMR $\left(75.5 \mathrm{MHz}, \mathrm{CDCl}_{3}\right):$ cis isomer $\delta 120.39(\mathrm{CN}), 47.71\left(\mathrm{C}-4^{\prime}\right), 36.76+36.43\left(\mathrm{C}-2^{\prime}+\mathrm{C} \cdot 6^{\prime}\right), 33.93$ $\left.\left(\mathrm{C}-1^{\prime}\right), 32.07\left(\mathrm{C} \mathrm{CH}_{3}\right)_{3}\right), 30.30(\mathrm{C}-3), 27.22\left(\mathrm{C}\left(\mathrm{CH}_{3}\right)_{3}\right), 22.72\left(\mathrm{C}-1^{\prime}-\right.$ $\left.\mathrm{CH}_{3}\right), 21.52+21.42\left(\mathrm{C}-3^{\prime}+\mathrm{C}-5^{\prime}\right), 19.11(\mathrm{C}-2), 13.28$ (C-4'); trans isomer $\delta 120.31(\mathrm{CN}), 47.82\left(\mathrm{C}-4^{\prime}\right), 42.21(\mathrm{C}-3), 35.95+35.87\left(\mathrm{C}-2^{\prime}\right.$ $\left.+\mathrm{C}-6^{\prime}\right), 34.38\left(\mathrm{C}-1^{\prime}\right), 31.98\left(\mathrm{C}\left(\mathrm{CH}_{3}\right)_{3}\right), 27.16\left(\mathrm{C}^{\prime}\left(\mathrm{CH}_{3}\right)_{3}\right), 22.37+22.28$ $\left(\mathrm{C}-3^{\prime}+\mathrm{C}-5^{\prime}\right), 19.23(\mathrm{C}-2), 16.60\left(\mathrm{C}-1^{\prime}-\mathrm{CH}_{3}\right), 13.68$ (C-4). High-resolution MS: Calcd for $\mathrm{C}_{14} \mathrm{H}_{24} \mathrm{~N}$ : 206.1909. Found: $206.1907\left(\mathrm{M}^{+}-\right.$ $\left.\mathrm{CH}_{3}\right), 153\left(\mathrm{M}^{+}-t-\mathrm{Bu}\right), 57(t-\mathrm{Bu})$

2-(4'-tert-Butyl-cis - $1^{\prime}$-methylcyclohexyl)butyrodinitrile. 4-tert-Butyl-1-methylcyclohexyl bromide, $935 \mathrm{mg}(4.0 \mathrm{mmol})$, and fumaronitrile, $636 \mathrm{mg}(8.0 \mathrm{mmol})$, are dissolved in benzene $(25 \mathrm{~mL})$. After degassing with a stream of dry nitrogen gas, the solution is heated to reflux. Tri- $n$-butyltin hydride, $1.75 \mathrm{~g}(6.0 \mathrm{mmol})$, and AIBN, $26 \mathrm{mg}(0.16$ mmol), in benzene ( $5 \mathrm{~mL}$ ) are added within $10 \mathrm{~min}$. Heating is continued for $1 \mathrm{~h}$. Standard $\mathrm{I}_{2} / \mathrm{KF}$ workup and flash chromatography on silica gel with pentane-ethyl acetate $(10: 1)$ yield $608 \mathrm{mg}(2.6 \mathrm{mmol})$ of unreacted 4-tert-butyl-1-methylcyclohexyl bromide and $295 \mathrm{mg} \mathrm{(32 \% )}$ of 2-(4'-tert-butyl-cis-1'-methylcyclohexyl)butyrodinitrile as a mixture of the cis and trans isomers in a ratio of 43:57 (by GC and ${ }^{1} \mathrm{H}$ NMR). The two isomers can be separated by further chromatography on silica gel with pentane-ethyl acetate (13:1) as eluent. ${ }^{1} \mathrm{H} \mathrm{NMR}(300 \mathrm{MHz}$, $\left.\mathrm{CDCl}_{3}\right)$ : cis isomer $\delta 0.89\left(\mathrm{~s}, 9 \mathrm{H}, \mathrm{C}\left(\mathrm{CH}_{3}\right)_{3}\right), 0.9-1.2(\mathrm{~m}, 1 \mathrm{H}), 1.06(\mathrm{~s}$, $\left.3 \mathrm{H}, \mathrm{C}-1^{\prime}-\mathrm{CH}_{3}\right), 1.25-1.40(\mathrm{~m}, 2 \mathrm{H}), 1.55-1.75(\mathrm{~m}, 5 \mathrm{H}), 2.04-2.10(\mathrm{~m}$, $1 \mathrm{H}), 2.60-2.63\left(\mathrm{~m}, 2 \mathrm{H}, \mathrm{C}-3-H_{2}\right), 3.28(\mathrm{dd}, 1 \mathrm{H}, J=7.4 \mathrm{~Hz}, \mathrm{C}, H)$ trans isomer $\delta 0.87\left(\mathrm{~s}, 9 \mathrm{H}, \mathrm{C}\left(\mathrm{CH}_{3}\right)_{3}\right), 0.9-1.03(\mathrm{~m}, 2 \mathrm{H}), 1.06(\mathrm{~s}, 3 \mathrm{H}$, $\left.\mathrm{C}-1^{\prime}-\mathrm{CH}_{3}\right), 1.12-1.41(\mathrm{~m}, 3 \mathrm{H}), 1.50-1.62(\mathrm{~m}, 2 \mathrm{H}), 1.63-1.78(\mathrm{~m}, 2$ $\mathrm{H}), 2.58-2.64(\mathrm{~m}, 3 \mathrm{H}, \mathrm{C}-2-\mathrm{H}+\mathrm{C}-3-\mathrm{H}) .{ }^{13} \mathrm{C}$ NMR $(75.5 \mathrm{MHz}$ $\left.\mathrm{CDCl}_{3}\right)$ : cis isomer $\delta 118.41+116.90(\mathrm{C}-1-\mathrm{N}+\mathrm{C}-4-\mathrm{N}), 47.34\left(\mathrm{C}-4^{\prime}\right)$, $34.96\left(\mathrm{C}-1^{\prime}\right), 37.95+34.13\left(\mathrm{C}-2^{\prime}+\mathrm{C}-6^{\prime}\right), 32.62(\mathrm{C}-2), 32.11\left(\mathrm{C}\left(\mathrm{CH}_{3}\right)_{3}\right)$ $27.18\left(\mathrm{C}\left(\mathrm{CH}_{3}\right)_{3}\right), 24.68\left(\mathrm{C}-1^{\prime}-\mathrm{CH}_{3}\right), 21.81+21.64\left(\mathrm{C}-3^{\prime}+\mathrm{C}-5^{\prime}\right), 15.87$ (C-3); trans isomer $\delta 118.27+116.85(\mathrm{C}-1-\mathrm{N}+\mathrm{C}-4-\mathrm{N}), 47.51\left(\mathrm{C}-4^{\prime}\right)$, $42.21(\mathrm{C}-2), 35.61\left(\mathrm{C}-1^{\prime}\right), 35.54\left(\mathrm{C}-2^{\prime}+\mathrm{C}-6^{\prime}\right), 32.13\left(\mathrm{C}\left(\mathrm{CH}_{3}\right)_{3}\right), 27.21$ $\left(\mathrm{C}\left(\mathrm{CH}_{3}\right)_{3}\right), 22.07+22.03\left(\mathrm{C}-3^{\prime}+\mathrm{C}-5^{\prime}\right), 18.53(\mathrm{C}-3), 15.95\left(\mathrm{C}-1^{\prime}-\mathrm{CH}_{3}\right)$ High resolution MS calcd for $\mathrm{C}_{14} \mathrm{H}_{21} \mathrm{~N}_{2}: 217.1705$. Found: 217.1706 $\left(\mathrm{M}^{+}-\mathrm{CH}_{3}\right) ; 175\left(\mathrm{M}^{+}-t-\mathrm{Bu}\right) ; 57(t-\mathrm{Bu})$

3-(4'-tert-Butyl-2'-methylcyclohexyl)propionitrile. To a solution of $840 \mathrm{mg} \mathrm{(3.0} \mathrm{mmol)} \mathrm{of} \mathrm{cis-4-tert-butyl-cis-2-methyl-1-iodocyclohexane}$ (6c) and $1.59 \mathrm{~g}(30 \mathrm{mmol})$ of acrylonitrile in anhydrous toluene $(30 \mathrm{~mL})$ are added at reflux within $150 \mathrm{~min}$ by syringe pump $1.05 \mathrm{~g}(3.6 \mathrm{mmol})$ of tri- $n$-butyltin hydride and $50 \mathrm{mg}(0.3 \mathrm{mmol})$ of AIBN in toluene (10 $\mathrm{mL}$ ). After workup and removal of low-boiling products by Kugelrohr distillation $\left(80^{\circ} \mathrm{C} / 15\right.$ Torr $)$ the residue is subjected to chromatography on silica gel with pentane-ether $(18: 1)$ as eluent. A second Kugelrohr distillation $\left(140^{\circ} \mathrm{C} / 15\right.$ Torr) yields $109 \mathrm{mg}(17 \%)$ of analytically pure 3-(4'-tert-butyl-2'-methylcyclohexyl)propionitrile as a mixture of the trans and cis isomers in a ratio of 79:21 (inverse-gated ${ }^{13} \mathrm{C} \mathrm{NMR}$ ) ${ }^{1} \mathrm{H}$ NMR $\left(300 \mathrm{MHz}, \mathrm{CDCl}_{3}\right)$ : trans isomer $\delta 0.73-2.14(\mathrm{~m}, 11 \mathrm{H}), 0.84(\mathrm{~s}$, $\left.9 \mathrm{H}, \mathrm{C}\left(\mathrm{CH}_{3}\right)_{3}\right), 1.05\left(\mathrm{~d}, J=7.3 \mathrm{~Hz}, 3 \mathrm{H}, \mathrm{C}-2^{\prime}-\mathrm{CH}_{3}\right), 2.22-2.42(\mathrm{~m}, 2$ $\mathrm{H}, \mathrm{CH} \mathrm{CN})$; cis isomer $\delta 0.73-2.14(\mathrm{~m}, 11 \mathrm{H}) ; 0.82\left(\mathrm{~s}, 9 \mathrm{H}, \mathrm{C}\left(\mathrm{CH}_{3}\right)\right.$, $0.93\left(\mathrm{~d}, J=6.4 \mathrm{~Hz}, 3 \mathrm{H}, \mathrm{CH}_{3}\right), 2.22-2.42\left(\mathrm{~m}, 2 \mathrm{H}, \mathrm{CH}_{2} \mathrm{CN}\right) .{ }^{13} \mathrm{C} \mathrm{NMR}$ $\left(75.5 \mathrm{MHz}, \mathrm{CDCl}_{3}\right)$ : trans isomer $\delta 120.16(\mathrm{CN}), 47.78\left(\mathrm{C}-4^{\prime}\right), 42.85$ $\left(\mathrm{C}-1^{\prime}\right), 37.03\left(\mathrm{C}-2^{\prime}\right), 36.73\left(\mathrm{C}-3^{\prime}\right), 32.28\left(\mathrm{C}^{\prime}\left(\mathrm{CH}_{3}\right)_{3}\right), 31.46\left(\mathrm{C}-6^{\prime}\right), 29.17$

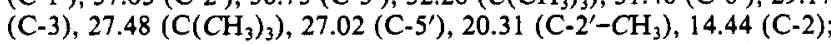
cis isomer $\delta 120.07(\mathrm{CN}), 48.17\left(\mathrm{C}-4^{\prime}\right), 37.46\left(\mathrm{C}-1^{\prime}\right), 35.65\left(\mathrm{C}-2^{\prime}\right), 32.41$ $\left(\mathrm{C}\left(\mathrm{CH}_{3}\right)_{3}\right), 30.14\left(\mathrm{C}-6^{\prime}\right), 28.89\left(\mathrm{C}-3^{\prime}\right), 27.37\left(\mathrm{C}^{\prime}\left(\mathrm{CH}_{3}\right)_{3}\right), 20.77(\mathrm{C}-3)$ $20.47\left(\mathrm{C}-5^{\prime}\right), 20.03\left(\mathrm{C}-2^{\prime}-C_{3}\right), 15.75(\mathrm{C}-2)$. MS (EI): $207\left(\mathrm{M}^{+}\right)$ Anal. Calcd for $\mathrm{C}_{14} \mathrm{H}_{25} \mathrm{~N}$ : C, 81.09; H, 12.15; N, 6.75. Found: $\mathrm{C}$, 81.05; H, 12.31; N, 6.52 .

3-(trans - $4^{\prime}$-tert-Butyl-trans -2-methylcyclohexyl)butyronitrile. (cis4'-tert-Butyl-cis-2'-methylcyclohexyloxy)thiocarbonylimidazole (b), 454 $\mathrm{mg}(1.95 \mathrm{mmol})$, and crotononitrile, $846 \mathrm{mg}(12.6 \mathrm{mmol})$, are dissolved in benzene $(20 \mathrm{~mL})$ and heated to reflux. Tri-n-butyltin hydride, 2.29 $\mathrm{g}(7.9 \mathrm{mmol})$, and AIBN, $101 \mathrm{mg}(0.6 \mathrm{mmol})$, in benzene $(10 \mathrm{~mL})$ are added within $14 \mathrm{~h}$. After heating is continued for $3 \mathrm{~h}$, the reaction mixture is worked up according to the $\mathrm{I}_{2} / \mathrm{KF}$ procedure. Flash chro- matography on silica gel with pentane-ethyl acetate (19:1) yields $302 \mathrm{mg}$ (46\%) of trans-3-(4'-tert-butyl-trans-2-methylcyclohexyl)butyronitrile as a mixture of two equatorial diastereomers in a $55: 45$ ratio (by ${ }^{13} \mathrm{C}$ NMR). ${ }^{1} \mathrm{H}$ NMR $\left(300 \mathrm{MHz}, \mathrm{CDCl}_{3}\right): \delta 0.83\left(\mathrm{~s}, 9 \mathrm{H}, \mathrm{C}\left(\mathrm{CH}_{3}\right)_{3}\right), 0.91$ $(\mathrm{t}, 3 \mathrm{H}, J=6.1 \mathrm{~Hz}), 0.83-1.10(\mathrm{~m}, 3 \mathrm{H}), 1.12(\mathrm{~d}, 3 \mathrm{H}, J=6.9 \mathrm{~Hz})$, $1.17-1.36(\mathrm{~m}, 2 \mathrm{H}), 1.51-1.56(\mathrm{~m}, 1 \mathrm{H}), 1.69-1.76(\mathrm{~m}, 2 \mathrm{H}), 1.79-1.85$ $(\mathrm{m}, 2 \mathrm{H}), 1.95-2.70(\mathrm{~m}, 1 \mathrm{H}), 2.21-2.34(\mathrm{~m}, 1 \mathrm{H}),{ }^{13} \mathrm{C}$ NMR $(75.5$ $\left.\mathrm{MHz}, \mathrm{CDCl}_{3}\right)$ : minor isomer $\delta 119.61(\mathrm{CN}), 47.61\left(\mathrm{C}-4^{\prime}\right), 46.68\left(\mathrm{C}-1^{\prime}\right)$,

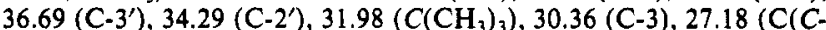
$\left.\left.\mathrm{H}_{3}\right)_{3}\right), 26.70\left(\mathrm{C}-5^{\prime}\right), 24.23\left(\mathrm{C}-6^{\prime}\right), 22.93(\mathrm{C}-2), 19.56\left(\mathrm{C}-1^{\prime}-\mathrm{CH}_{3}\right), 12.65$ (C-4); major isomer $\delta 120.36(\mathrm{CN}), 48.34\left(\mathrm{C}-4^{\prime}\right), 46.68\left(\mathrm{C}-1^{\prime}\right), 36.69$

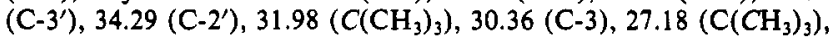
$\left.26.70\left(\mathrm{C}^{\prime}\right)^{\prime}\right), 24.23\left(\mathrm{C}-6^{\prime}\right), 22.93(\mathrm{C}-2), 19.56\left(\mathrm{C}-2^{\prime}-\mathrm{CH}_{3}\right), 12.54(\mathrm{C}-4)$. High-resolution MS calcd for $\mathrm{C}_{14} \mathrm{H}_{21} \mathrm{~N}_{2}:$ 217.1705. Found: 217.1706 $\left(\mathrm{M}^{+}-\mathrm{CH}_{3}, 19 \%\right), 166\left(\mathrm{M}^{+}-66,19 \%\right), 57(t-\mathrm{Bu}, 100 \%)$.

2-(trans -4'-tert-Butyl-trans -2'-methylcyclohexyl)butyrodinitrile. cis4-tert-Butyl-cis-2-methyl-1-iodocyclohexane (6c), $840 \mathrm{mg}(3.0 \mathrm{mmol})$, and fumaronitrile, $2.34 \mathrm{~g}(30 \mathrm{mmol})$, are dissolved in toluene $(30 \mathrm{~mL})$ and heated to reflux under nitrogen. Tri- $n$-butyltin hydride, $1.05 \mathrm{~g}(3.6$ $\mathrm{mmol})$, and AIBN, $50 \mathrm{mg}(0.3 \mathrm{mmol})$, are dissolved in toluene $(10 \mathrm{~mL})$ and added with a syringe pump to the refluxing reaction mixture within $120 \mathrm{~min}$. After general workup the low-boiling products are removed by Kugelrohr distillation $\left(100^{\circ} \mathrm{C} / 15\right.$ Torr $)$ and the residue is purified by chromatography on silica gel with hexane-ether $(8: 2)$. This yields 204 $\mathrm{mg}$ (29\%) of 2-(trans-4'-tert-butyl-trans-2'-methylcyclohexyl)butanedinitrile. Only the equatorial addition product is found, which consists of two diastereomers in a 54:46 ratio (inverse-gated ${ }^{13} \mathrm{C}$ NMR). ${ }^{1} \mathrm{H}$ NMR $\left(300 \mathrm{MHz}, \mathrm{CDCl}_{3}\right)$ : major isomer $\delta 0.84\left(\mathrm{~s}, 9 \mathrm{H}, \mathrm{C}\left(\mathrm{CH}_{3}\right)_{3}\right), 0.97(\mathrm{~d}, J$ $\left.=6.5 \mathrm{~Hz}, 3 \mathrm{H}, \mathrm{CH}_{3}\right), 1.02-2.86(\mathrm{~m}, 12 \mathrm{H})$; minor isomer $\delta 0.85(\mathrm{~s}, 9$ $\mathrm{H}, \mathrm{C}\left(\mathrm{CH}_{3}\right), 0.99(\mathrm{~d}, J=6.7 \mathrm{~Hz}, 3 \mathrm{H}, \mathrm{CH}), 1.02-2.86(\mathrm{~m}, 12 \mathrm{H}){ }^{13} \mathrm{C}$ NMR (75.5 MHz, $\left.\mathrm{CDCl}_{3}\right)$ : major isomer $\delta 119.25+116.17(\mathrm{C}-1-\mathrm{N}+$ $\mathrm{C}-4-\mathrm{N}), 47.45\left(\mathrm{C}-4^{\prime}\right), 45.47\left(\mathrm{C}-1^{\prime}\right), 36.55\left(\mathrm{C}-3^{\prime}\right), 34.10\left(\mathrm{C}-2^{\prime}\right), 32.23$ $\left(\mathrm{C}\left(\mathrm{CH}_{3}\right)_{3}\right), 31.11(\mathrm{C}-3), 28.56\left(\mathrm{C}-6^{\prime}\right), 27.38\left(\mathrm{C}\left(\mathrm{CH}_{3}\right)_{3}\right), 26.81\left(\mathrm{C}-5^{\prime}\right)$, $19.98\left(\mathrm{C}^{\prime}{ }^{\prime}-\mathrm{CH}_{3}\right), 16.33(\mathrm{C}-2)$; minor isomer $\delta 117.60+116.73(\mathrm{C}-1-\mathrm{N}$ $+\mathrm{C}-4-\mathrm{N}), 47.10\left(\mathrm{C}-4^{\prime}\right), 44.51\left(\mathrm{C}-1^{\prime}\right), 36.20\left(\mathrm{C}-3^{\prime}\right), 35.27\left(\mathrm{C}-2^{\prime}\right), 32.23$ $\left(\mathrm{C}\left(\mathrm{CH}_{3}\right)_{3}\right), 30.85(\mathrm{C}-3), 27.39\left(\mathrm{C}\left(\mathrm{CH}_{3}\right)_{3}\right), 26.90\left(\mathrm{C}-6^{\prime}\right), 26.38\left(\mathrm{C}-5^{\prime}\right)$, $19.81\left(\mathrm{C}-2^{\prime}-\mathrm{CH}_{3}\right), 18.99(\mathrm{C}-2)$. Anal. Calcd for $\mathrm{C}_{15} \mathrm{H}_{24} \mathrm{~N}_{2}$ : C, 77.53 ; H, $10.41 ; N, 12.06$. Found: C, 77.41; H, 10.53; N, 11.97 .

3-(cis-4'-tert-Butyl- and 3-(trans -4'-tert-Buty)-cis-2'-methylcyclohexyl)propionitrile. [[( cis $^{-} \mathbf{4}^{\prime}$-tert-Butyl-trans-2'-methylcyclohexyl)oxy] thiocarbonyl]imidazole (7b) $(125 \mathrm{mg}, 0.45 \mathrm{mmol})$ and $101 \mathrm{mg}(19$ $\mathrm{mmol})$ of acrylonitrile are dissolved in benzene $(10 \mathrm{~mL})$ and heated to reflux. A second solution of $180 \mathrm{mg}(0.62 \mathrm{mmol})$ of tri-n-butylstannane and $17 \mathrm{mg}(0.1 \mathrm{mmol})$ of AIBN in benzene $(5 \mathrm{~mL})$ are added within 5 $\mathrm{h}$ by syringe pump. Heating is continued for $3 \mathrm{~h}$. The reaction mixture is worked up according to the $\mathrm{I}_{2} / \mathrm{KF}$ procedure, and the residue is purified by flash chromatography on silica gel with pentane-ethyl acetate $(19: 1)$ as eluent. Thus, $62 \mathrm{mg}(66 \%)$ 3-(cis-4'-tert-butyl-trans-2'methylcyclohexyl)propionitrile and 3-(trans-4'-tert-butyl-cis-2'-methylcyclohexyl)propionitrile are obtained in a $90: 10$ ratio (by GC and ${ }^{13} \mathrm{C}$ NMR). ${ }^{1} \mathrm{H}$ NMR $\left(300 \mathrm{MHz}, \mathrm{CDCl}_{3}\right)$ : cis isomer $\delta 0.82(\mathrm{~s}, 9 \mathrm{H}$, $\left.\mathrm{C}\left(\mathrm{CH}_{3}\right)_{3}\right), 1.06\left(\mathrm{~d}, J=7.2 \mathrm{~Hz}, 3 \mathrm{H}, \mathrm{C}-2^{\prime}-\mathrm{CH}_{3}\right), 0.84-1.20(\mathrm{~m}, 2 \mathrm{H})$, $1.20-1.56(\mathrm{~m}, 9 \mathrm{H}), 1.62-1.84(\mathrm{~m}, 2 \mathrm{H}), 2.30-2.37(\mathrm{~m}, 1 \mathrm{H})$; trans isomer $\delta 0.82\left(\mathrm{~s}, 9 \mathrm{H}, \mathrm{C}\left(\mathrm{CH}_{3}\right)_{3}\right), 0.8-1.06(\mathrm{~m}, 2 \mathrm{H}), 1.06(\mathrm{~d}, J=7.2 \mathrm{~Hz}$ $\left.3 \mathrm{H}, \mathrm{C}-2^{\prime}-\mathrm{CH}_{3}\right), 1.15-1.85(\mathrm{~m}, 8 \mathrm{H}), 2.34\left(\mathrm{t}, 2 \mathrm{H}, J=7.4 \mathrm{~Hz}, \mathrm{CH}_{2} \mathrm{CN}\right)$. ${ }^{13} \mathrm{C}$ NMR $\left(75.5 \mathrm{MHz}, \mathrm{CDCl}_{3}\right)$ : cis isomer $\delta 120.20(\mathrm{CN}), 40.85\left(\mathrm{C}-4^{\prime}\right)$, $37.50\left(\mathrm{C}-1^{\prime}\right), 32.06\left(\mathrm{C}\left(\mathrm{CH}_{3}\right)_{3}\right), 31.82\left(\mathrm{C}-2^{\prime}\right), 28.22\left(\mathrm{C}-3^{\prime}\right), 27.61\left(\mathrm{C}-6^{\prime}\right)$, $27.16\left(\mathrm{C}\left(\mathrm{CH}_{3}\right)_{3}\right), 24.15\left(\mathrm{C}-5^{\prime}\right), 21.40(\mathrm{C}-3), 19.55\left(\mathrm{C}-2^{\prime}-\mathrm{CH}_{3}\right), 15.38$ (C-2): trans isomer $\delta 119.80(\mathrm{CN}), 40.65\left(\mathrm{C}-4^{\prime}\right), 39.04\left(\mathrm{C}-1^{\prime}\right), 34.18$ (C-3'), $31.82\left(\mathrm{C}\left(\mathrm{CH}_{3}\right)_{3}\right), 31.73(\mathrm{C}-3), 30.59\left(\mathrm{C}-2^{\prime}\right), 29.16\left(\mathrm{C}-6^{\prime}\right), 28.86$ (C-5'), $\left.27.24\left(\mathrm{C}^{\prime} \mathrm{CH}_{3}\right)_{3}\right), 14.70(\mathrm{C}-2), 12.00\left(\mathrm{C}^{\prime} \mathbf{2}^{\prime}-\mathrm{CH}_{3}\right)$. Anal. Calcd for $\mathrm{C}_{14} \mathrm{H}_{25} \mathrm{~N}$ : C, 81.09; $\mathrm{H}, 12.15 ; \mathrm{N}, 6.75$. Found: $\mathrm{C}, 81.27 ; \mathrm{H}, 11.86$; $\mathrm{N}, 6.74$.

3-(cis-4'-tert-Butyl-trans - $2^{\prime}$-methylcyclohexyl)butyronitrile and 3(trans - 4'-tert -Butyl-cis -2'-methylcyclohexyl) butyronitrile. [ [ (cis-4'tert-Butyl-trans-2'-methylcyclohexyl)oxy] thiocarbonyl]imidazole (7b), $148 \mathrm{mg}(0.54 \mathrm{mmol})$, and $182 \mathrm{mg}(2.7 \mathrm{mmol})$ of crotononitrile are dissolved in benzene $(15 \mathrm{~mL})$ and heated to reflux. Within $5 \mathrm{~h}$ a solution of $232 \mathrm{mg}(0.81 \mathrm{mmol})$ of tri- $n$-butylstannane and $14 \mathrm{mg}(0.085 \mathrm{mmol})$ of AIBN in benzene $(5 \mathrm{~mL})$ is added by syringe pump. Workup according to the $I_{2} / K F$ procedure and flash chromatography on silica gel with pentane-ethyl acetate $(19: 1)$ yield $72 \mathrm{mg}(60 \%)$ of a $83: 17$ mixture of 3-(cis-4'-tert-butyl-trans-2'-methylcyclohexyl)butyronitrile and 3 (trans-4'-tert-butyl-cis-2'-methylcyclohexyl)butyronitrile. 'H NMR (300 $\mathrm{MHz}, \mathrm{CDCl}_{3}$ ): cis isomer (major) $80.81\left(\mathrm{~s}, 9 \mathrm{H}, \mathrm{C}\left(\mathrm{CH}_{3}\right)_{3}\right), 0.72-1.02$ $(\mathrm{m}, 2 \mathrm{H}), 1.05\left(\mathrm{~d}, 3 \mathrm{H}, J=7.2 \mathrm{~Hz}, \mathrm{C}-2^{\prime}-\mathrm{CH}_{3}\right), 1.08(\mathrm{~d}, 3 \mathrm{H}, J=6.8$ $\left.\mathrm{Hz}, \mathrm{C}-4-H_{3}\right), 1.18-1.37(\mathrm{~m}, 3 \mathrm{H}), 1.44-1.81(\mathrm{~m}, 3 \mathrm{H}), 1.84-2.08(\mathrm{~m}, 2$ $\mathrm{H}), 2.23-2.32(\mathrm{~m}, 1 \mathrm{H}, \mathrm{CHCN}), 2.38-2.46(\mathrm{~m} .1 \mathrm{H}, \mathrm{CHCN})$; cis isomer (minor) $\delta 0.82\left(\mathrm{~s}, 9 \mathrm{H}, \mathrm{C}\left(\mathrm{CH}_{3}\right)_{3}\right), 0.72-1.02(\mathrm{~m}, 2 \mathrm{H}), 1.06(\mathrm{~d}, 3 \mathrm{H}, J$ $\left.=7.2 \mathrm{~Hz}, \mathrm{C}-2^{\prime}-\mathrm{CH}_{3}\right), 1.12\left(\mathrm{~d}, 3 \mathrm{H}, J=6.8 \mathrm{~Hz}, \mathrm{C}-4-H_{3}\right), 1.18-1.37(\mathrm{~m}$, 
$3 \mathrm{H}), 1.44-1.81(\mathrm{~m}, 3 \mathrm{H}), 1.84-2.08(\mathrm{~m}, 2 \mathrm{H}), 2.23-2.32(\mathrm{~m}, 1 \mathrm{H}$ $\mathrm{CHCN}), 2.38-2.46(\mathrm{~m}, 1 \mathrm{H}, \mathrm{CHCN}) .{ }^{13} \mathrm{C} \mathrm{NMR}\left(75.5 \mathrm{MHz}, \mathrm{CDCl}_{3}\right)$ : $4^{\prime}$-cis-isomer $\delta 119.11 / 119.14(\mathrm{CN}), 42.93 / 42.86\left(\mathrm{C}-1^{\prime}\right), 40.76 / 40.79$ $\left.\left(\mathrm{C}-4^{\prime}\right), 32.25 / 32.29\left(\mathrm{C}_{(\mathrm{CH}}\right)_{3}\right), 29.48 / 29.51\left(\mathrm{C}-6^{\prime}\right), 28.93 / 29.98\left(\mathrm{C}-2^{\prime}\right)$, $27.83 / 28.23\left(\mathrm{C}-3^{\prime}\right), 27.34\left(\mathrm{C}\left(\mathrm{CH}_{3}\right)_{3}\right), 22.97 / 22.46\left(\mathrm{C}-5^{\prime}\right), 22.11 / 23.33$ (C-3), 22.02/22.02 (C-2), 19.98/19.94 (C-4), 18.31/17.79 (C-2'-CH $)_{3}$; $4^{\prime}$-trans-isomer 118.9/118.9(CN), 44.23/44.30 (C-1'), $40.52\left(\mathrm{C}^{\prime} 4^{\prime}\right)$ 34.66/34.60 (C-3'), $32.49\left(\mathrm{C}\left(\mathrm{CH}_{3}\right)_{3}\right), 32.25 / 32.03(\mathrm{C}-3), 29.17 / 29.67$ (C-6'), $27.30\left(\mathrm{C}-2^{\prime}+\mathrm{C}-5^{\prime}+\mathrm{C}\left(\mathrm{CH}_{3}\right)_{3}\right), 24.71 / 24.29(\mathrm{C}-2), 17.44 / 18.08$ (C-4), 12.55/12.38 (C-2'-CH$)_{3}$. MS (EI): $206\left(\mathrm{M}^{+}-\mathrm{CH}_{3}, 38 \%\right), 166$ $\left(\mathrm{M}^{+}-55,23 \%\right), 164\left(\mathrm{M}^{+}-t \cdot \mathrm{Bu}, 8 \%\right), 57(t-\mathrm{Bu}, 100 \%)$. Anal. Calcd for $\mathrm{C}_{15} \mathrm{H}_{27} \mathrm{~N}$ : C, 81.38; H, 12.29; N, 6.33. Found: C, 81.52; H, 12.01; N, 6.17.

3-(3-tert-Butylcyclohexyl)propionitrile. A solution of $532 \mathrm{mg}(2.00$ mmol) of 3-tert-butyl-1-iodocyclohexane $(10)$ and $1.06 \mathrm{~g}(20 \mathrm{mmol})$ of acrylonitrile in anhydrous toluene $(20 \mathrm{~mL})$ is heated to reflux under a nitrogen atmosphere. A solution of $610 \mathrm{mg}(2.1 \mathrm{mmol})$ of tri- $n$-butyltin hydride and $33 \mathrm{mg}(0.2 \mathrm{mmol})$ of AIBN in toluene $(4 \mathrm{~mL})$ is then added within $100 \mathrm{~min}$ by syringe pump. After workup, the residue is chromatographed on silica gel with pentane-ether $(9: 1)$, which yields $86 \mathrm{mg}$ (22\%) of 3-(3-tert-butylcyclohexyl)propionitrile as a mixture of diastereomers. The trans/cis ratio was determined to be $56: 44$ (inverse-gated $\left.{ }^{13} \mathrm{C} \mathrm{NMR}\right){ }^{1} \mathrm{H}$ NMR $\left(300 \mathrm{MHz}, \mathrm{CDCl}_{3}\right)$ : cis isomer $\delta 0.83(\mathrm{~s}, 9 \mathrm{H}$, $\left.\mathrm{C}\left(\mathrm{CH}_{3}\right)_{3}\right), 0.57-2.01(\mathrm{~m}, 12 \mathrm{H}), 2.31\left(\mathrm{t}, J=7.4 \mathrm{~Hz}, 2 \mathrm{H}, \mathrm{CH}_{2} \mathrm{CN}\right)$ trans isomer $0.84\left(\mathrm{~s}, 9 \mathrm{H}, \mathrm{C}\left(\mathrm{CH}_{3}\right)_{3}\right), 0.57-2.01(\mathrm{~m}, 12 \mathrm{H}), 2.36(\mathrm{t}, J=$ $\left.7.4 \mathrm{~Hz}, 2 \mathrm{H}, \mathrm{CH}_{2} \mathrm{CN}\right) .{ }^{13} \mathrm{C} \mathrm{NMR}\left(75.5 \mathrm{MHz}, \mathrm{CDCl}_{3}\right): 3^{\prime}$-cis isomer $\delta 119.97(\mathrm{CN}), 41.62\left(\mathrm{C}-3^{\prime}\right), 32.73\left(\mathrm{C}-1^{\prime}\right), 32.35(\mathrm{C}-3), 32.29\left(\mathrm{C}\left(\mathrm{CH}_{3}\right)_{3}\right)$, $30.45\left(\mathrm{C}-6^{\prime}\right), 29.21\left(\mathrm{C}-2^{\prime}\right), 27.35\left(\mathrm{C}\left(\mathrm{CH}_{3}\right), 27.20\left(\mathrm{C}-4^{\prime}\right), 21.43\left(\mathrm{C}-5^{\prime}\right)\right.$ $15.58(\mathrm{C}-2) ; 3^{\prime}$-trans isomer $\delta 120.05(\mathrm{CN}), 47.72\left(\mathrm{C}-3^{\prime}\right), 37.19\left(\mathrm{C}-1^{\prime}\right)$, $33.76\left(\mathrm{C}-2^{\prime}\right), 32.99\left(\mathrm{C}-6^{\prime}\right), 32.45\left(\mathrm{C}\left(\mathrm{CH}_{3}\right)_{3}\right), 32.35(\mathrm{C}-3), 27.50(\mathrm{C}(\mathrm{C}-$ $\left.\left.\mathrm{H}_{3}\right)_{3}\right), 27.14\left(\mathrm{C}-4^{\prime}\right), 26.32\left(\mathrm{C}-5^{\prime}\right), 14.72$ (C-2). Anal. Calcd for $\mathrm{C}_{13} \mathrm{H}_{23} \mathrm{~N}$ : $\mathrm{C}, 80.76 ; \mathrm{H}, 11.99 ; \mathrm{N}, 7.25$. Found: C, 80.72; H, 11.90; N, 7.10 .

3-(10-Methyl-trans-2'-decalinyl)propionitrile. A degassed solution of $132 \mathrm{mg}(0.47 \mathrm{mmol})$ of $\left[\left(10^{\prime}\right.\right.$-methyl-trans-decaliny]-2' $\beta$-oxy)thiocarbonyl limidazole (13a) and $97 \mathrm{mg}(1.83 \mathrm{mmol})$ of acrylonitrile in dry benzene $(10 \mathrm{~mL})$ is heated to reflux. Within $5 \mathrm{~h}$ a solution of $230 \mathrm{mg}$ $(0.79 \mathrm{mmol})$ tri- $n$-butylstannane and $19 \mathrm{mg}(0.12 \mathrm{mmol})$ of AIBN in benzene $(4 \mathrm{~mL})$ is added. After heating for one more hour, the reaction mixture is worked up according to the $\mathrm{I}_{2} / \mathrm{KF}$ procedure. Chromatography on silica gel with pentane-ethyl acetate (19:1) yields $48 \mathrm{mg} \mathrm{(50 \% )}$ of $3-\left(10^{\prime}\right.$-methyl-trans-2' $\alpha$-decalinyl $)$ propionitrile and $3-\left(10^{\prime}\right.$-methyltrans-2' $\beta$-decalinyl)propionitrile in a ratio of $97: 3$ (by GC and GC/MS) 'H NMR (300 MHz, CDCl $)$ ): $2^{\prime} \alpha$-isomer $\delta 0.73(\mathrm{~m}, 1 \mathrm{H}), 0.84(\mathrm{~s}, 3$ $\left.\mathrm{H}, \mathrm{CH}_{3}\right), 0.85-1.80(\mathrm{~m}, 17 \mathrm{H}), 2.34(\mathrm{t}, 2 \mathrm{H}, \mathrm{CH}, \mathrm{CN}, J=7.7 \mathrm{~Hz}) .{ }^{13} \mathrm{C}$ NMR $\left(101 \mathrm{MHz}, \mathrm{CDCl}_{3}\right)$ : $2^{\prime} \alpha$-isomer $\delta 120.02(\mathrm{CN}), 48.16\left(\mathrm{C}-1^{\prime}\right)$ $45.50\left(\mathrm{C}-5^{\prime}\right), 41.72\left(\mathrm{C}-9^{\prime}\right), 34.64\left(\mathrm{C}-10^{\prime}\right), 33.02\left(\mathrm{C}-3^{\prime}\right), 32.80(\mathrm{C}-3)$ $31.82\left(\mathrm{C}-2^{\prime}\right), 28.54\left(\mathrm{C}-4^{\prime}+\mathrm{C}-6^{\prime}\right), 27.00\left(\mathrm{C}-7^{\prime}\right), 21.67\left(\mathrm{C}-8^{\prime}\right), 16.33$ $\left(\mathrm{C}-10^{\prime}-\mathrm{CH}_{3}\right), 14.69(\mathrm{C}-2) ; 2^{\prime} \beta$-isomer $120.02(\mathrm{CN}), 45.6\left(\mathrm{C}-1^{\prime}\right), 45.77$ (C-5'), $42.00\left(\mathrm{C}-9^{\prime}\right), 33.80\left(\mathrm{C}-10^{\prime}\right), 31.01\left(\mathrm{C}-3^{\prime}\right), 29.04\left(\mathrm{C}-6^{\prime}\right), 27.29$ (C-7'), 26.94 (C-3), $24.84\left(\mathrm{C}-4^{\prime}\right), 21.39$ (C-8'), $18.27\left(\mathrm{C}-2^{\prime}\right), 16.38$ (C-2), $13.62\left(\mathrm{C}-10^{\prime}-\mathrm{CH}_{3}\right)$. High-resolution MS calcd for $\mathrm{C}_{14} \mathrm{H}_{23} \mathrm{~N}: 205.1831$ Found: $205.1836\left(\mathrm{M}^{+}, 17 \%\right), 190\left(\mathrm{M}^{+}-\mathrm{CH}_{3}, 100 \%\right), 176\left(\mathrm{M}^{+}-29\right.$ $39 \%)$.

3-(10'-Methyl-trans-2'-decalinyl)butyronitrile. A degassed solution of $149 \mathrm{mg}(0.54 \mathrm{mmol})$ of [ $\left(10^{\prime}\right.$-methyl-trans-decalinyl-2' $\beta$-oxy)thiocarbonyl]imidazole and $361 \mathrm{mg}(5.4 \mathrm{mmol})$ of crotononitrile in dry benzene $(20 \mathrm{~mL})$ is heated to reflux. Within $5 \mathrm{~h}$ a solution of $247 \mathrm{mg}$ $(0.79 \mathrm{mmol})$ of tri-n-butylstannane and $20 \mathrm{mg}(0.12 \mathrm{mmol})$ of AIBN in benzene $(4 \mathrm{~mL})$ is added. After heating for $1 \mathrm{~h}$, the reaction mixture is worked up following the $I_{2} / K F$ procedure. After chromatography on silica gel with pentane-ethyl acetate $(19: 1) 51 \mathrm{mg}(43 \%)$ of $3-\left(10^{\prime}\right.$ methyl-trans-2' $\alpha$-decalinyl)butyronitrile is obtained as a mixture of two diastereomers. GC and GC/MS spectrometry show, that the product containes one further isomer $(<2 \%)$, with a mass spectrum identical with that of the main compound. 'H NMR ( $\left.400 \mathrm{MHz}, \mathrm{CDCl}_{3}\right): 2^{\prime} \alpha$-isomer $\delta 0.83\left(\mathrm{~s}, 3 \mathrm{H}, \mathrm{C}-10^{\prime}-\mathrm{CH}_{3}\right), 1.037 / 1.043\left(\mathrm{~d}, 3 \mathrm{H}, J=6.6 \mathrm{~Hz}, \mathrm{C}_{4} H_{3}\right)$, $0.9-1.4(\mathrm{~m}, 5 \mathrm{H}), 1.45-1.75(\mathrm{~m}, 6 \mathrm{H}), 2.22 / 2.26(\mathrm{~d}, 1 \mathrm{H}, J=7.5 \mathrm{~Hz}$ $\mathrm{C} H \mathrm{CN}), 2.35 / 2.37\left(\mathrm{dd}, 1 \mathrm{H}, J=2.9 \mathrm{~Hz}, 4.9 \mathrm{~Hz}, \mathrm{CH}^{\prime} \mathrm{CN}\right) .{ }^{13} \mathrm{C} \mathrm{NMR}$ (75.5 $\left.\mathrm{MHz} \mathrm{CDCl}_{3}\right): 2^{\prime} \alpha$-isomer $\delta 119.75 / 119.20(\mathrm{CN}), 45.75 / 44.49$ (C-1'), 45.36 (C-5'), 41.75 (C-9'), 36.42/36.37 (C-2'), 35.58/35.55 (C-3), 33.94/33.83 (C-10'), 30.66/29.45 (C-3'), 28.45/28.60 (C-4') $28.38\left(\mathrm{C}-6^{\prime}\right), 26.88\left(\mathrm{C}-7^{\prime}\right), 22.07 / 22.19(\mathrm{C}-2), 21.59\left(\mathrm{C}-8^{\prime}\right), 16.59 / 16.52$ and 16.24/16.20 (C-10'- $\left.\mathrm{CH}_{3}+\mathrm{C}-4\right)$. High-resolution MS calcd for $\mathrm{C}_{15} \mathrm{H}_{25} \mathrm{~N}: 219.1987$. Found: $219.1992\left(\mathrm{M}^{+}, 12 \%\right), 204\left(\mathrm{M}^{+}-\mathrm{CH}_{3}\right.$, $72 \%), 190\left(\mathbf{M}^{+}-29,20 \%\right)$

3-(10'-Methyl-trans -2' $\alpha$-decalinyl) butyrodinitrile. To a solution of 420 $\mathrm{mg}(1.80 \mathrm{mmol})$ of $2 \alpha, \beta$-bromo- 10 -methyl-trans-decalin and $141 \mathrm{mg}(1.8$ mmol) of fumaronitrile in dry benzene $(10 \mathrm{~mL})$ is added at reflux within $1 \mathrm{~h}$ a solution of $1.4 \mathrm{~g}(4.92 \mathrm{mmol})$ of tri-n-butylstannane, $17 \mathrm{mg}(0.1$

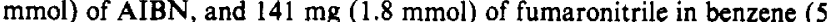
$\mathrm{mL}$ ). Heating is continued for $1 \mathrm{~h}$. Then the reaction mixture is worked up as usual and the residue chromatographed on silica gel with pentane-ethyl acetate $(5: 1)$. This yields $120 \mathrm{mg}(29 \%)$ of 3-(10'-methyltrans-2' $\alpha$-decalinyl)butyrodinitrile as a mixture of the diastereomers at $\mathrm{C}-3$. GC and GC/MS spectrometry show that the product contains one further isomer $(<2 \%)$, with a mass spectrum identical with that of the main compound. 'H NMR (300 $\left.\mathrm{MHz}, \mathrm{CDCl}_{3}\right)$ : 2' $\alpha$-isomer $\delta 0.87$ (s, $\left.3 \mathrm{H}, \mathrm{C}-10^{\prime}-\mathrm{CH}_{3}\right), 0.9-1.6(\mathrm{~m}, 12 \mathrm{H}), 1.65-1.80(\mathrm{~m}, 2 \mathrm{H}), 1.85-2.10(\mathrm{~m}$, $2 \mathrm{H}), 2.60-2.80\left(\mathrm{~m}, 3 \mathrm{H}, \mathrm{C}-3-\mathrm{H}+\mathrm{C}-2-\mathrm{H}_{2}\right) .{ }^{13} \mathrm{C}$ NMR $(75.5 \mathrm{MHz}$, $\left.\mathrm{CDCl}_{3}\right): \quad 2^{\prime} \alpha$-isomer $\delta 118.15(\mathrm{C}-1-\mathrm{N}), 115.78 / 115.81 \quad(\mathrm{C}-4-\mathrm{N})$ 46.11/43.89 (C-1'), 44.87 (C-5'), 41.34/41.31 (C-9'), 34.74/34.65 (C$\left.2^{\prime}\right)$, 34.15/33.95 (C-10'), 34.08 (C-3), 31.30/29.11 (C-3'), $28.22\left(\mathrm{C}-6^{\prime}\right)$, $27.97 / 27.76\left(\mathrm{C}-4^{\prime}\right), 26.73\left(\mathrm{C}-7^{\prime}\right), 21.46\left(\mathrm{C}-8^{\prime}\right), 18.78 / 18.73(\mathrm{C}-2), 16.17$ $\left(\mathrm{ClO}^{\prime}-\mathrm{CH}_{3}\right)$. High-resolution MS calcd for $\mathrm{C}_{15} \mathrm{H}_{22} \mathrm{~N}_{2}: 230.1783$. Found: $230.1769\left(\mathrm{M}^{+}, 8 \%\right), 215\left(\mathrm{M}^{+}-\mathrm{CH}_{3}, 100 \%\right), 201\left(\mathrm{M}^{+}-29\right.$, 22\%).

Abstraction Reactions. Workup procedures for abstraction reactions are identical with those described for the addition reactions.

4-Deuterio-1-tert-butylcyclohexane. 4-tert-Butylcyclohexyl bromide $(1.61 \mathrm{~g}, 7.4 \mathrm{mmol})$ is dissolved in benzene $(40 \mathrm{~mL})$ and heated to reflux under nitrogen. A solution of $300 \mathrm{mg}(1.83 \mathrm{mmol})$ of AIBN and 3.67 $\mathrm{g}(12.6 \mathrm{mmol})$ of tri- $n$-butyldeuteriostannane in benzene $(20 \mathrm{~mL})$ is added within $3 \mathrm{~h}$. Heating is continued for $1 \mathrm{~h}$. Then the reaction mixture is worked up according to the KF method. The residue is purified by Kugelrohr distillation $\left(80^{\circ} \mathrm{C} / 15 \mathrm{mbar}\right.$ ), which yields $200 \mathrm{mg}$ (19\%) of 4-dueterio-1-tert-butylcyclohexane with a trans:cis ratio of 30:70 (by $\left.{ }^{2} \mathrm{H} \mathrm{NMR}\right) .{ }^{1} \mathrm{H}$ NMR $\left(300 \mathrm{MHz}, \mathrm{CDCl}_{3}\right): \delta 0.85\left(\mathrm{~s}, 9 \mathrm{H}, \mathrm{C}\left(\mathrm{CH}_{3}\right)_{3}\right)$, $0.82-1.25(\mathrm{~m}, 5 \mathrm{H}), 1.25-1.44(\mathrm{~m}, 1 \mathrm{H}), 1.58-1.69(\mathrm{~m}, 1 \mathrm{H}), 1.69-1.81$ (m, $4 \mathrm{H}) .{ }^{2} \mathrm{H}$ NMR (46.07 MHz, $\mathrm{CHCl}_{3}$ ): cis isomer $\delta 1.26$ (br s); trans isomer $\delta 1.72(\mathrm{br} \mathrm{s}) .{ }^{13} \mathrm{C} \mathrm{NMR}\left(75.5 \mathrm{MHz}, \mathrm{CDCl}_{3}\right): \delta 48.34(\mathrm{C}-1)$,

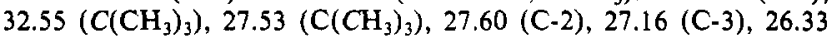
$\left(\mathrm{t}(1: 1: 1), J_{\mathrm{CD}}=19.2 \mathrm{~Hz}, \mathrm{C}-4\right)$. MS (EI): $141\left(\mathrm{M}^{+}, 3 \%\right), 126\left(\mathrm{M}^{+}-\right.$ $\left.\mathrm{CH}_{3}, 6 \%\right), 84\left(\mathrm{M}^{+}-t-\mathrm{Bu}, 21 \%\right), 57(t-\mathrm{Bu}, 100 \%)$. Anal. Calcd for $\mathrm{C}_{10} \mathrm{H}_{19} \mathrm{D}: \mathrm{C}, 85.03 ; \mathrm{H}, 14.97$. Found: $\mathrm{C}, 85.61 ; \mathrm{H}, 14.19$.

4-tert-Butylcyclohexyl Bromide. In $30 \mathrm{~mL}$ of benzene are dissolved under argon $210 \mathrm{mg}(0.5 \mathrm{mmol})$ of trans-4-tert-butylcyclohexylmercury bromide ${ }^{7}$ and $991 \mathrm{mg}(5.0 \mathrm{mmol})$ of bromotrichloromethane. After heating to $68^{\circ} \mathrm{C}$, a solution of $150 \mathrm{mg}(4.0 \mathrm{mmol}) \mathrm{NaBH}_{4}$ in water $(1.5$ $\mathrm{mL}$ ) is added at once. Stirring is continued for $30 \mathrm{~min}$ and the reaction mixture is filtered through anhydrous $\mathrm{MgSO}_{4}$. The soivent is evaporated and Kugelrohr distillation of the residue yields cis-4-tert-butylcyclohexyl bromide and trans-4-tert-butylcyclohexyl bromide in a ratio of 69:31 (by $\mathrm{GC}$ and ${ }^{1} \mathrm{H}$ NMR). ${ }^{1} \mathrm{H}$ NMR ( $300 \mathrm{MHz}, \mathrm{CDCl}_{3}$ ): cis isomer $\delta 0.88$ $\left(\mathrm{s}, 9 \mathrm{H}, \mathrm{C}\left(\mathrm{CH}_{3}\right)_{3}\right), 0.94-1.11(\mathrm{~m}, 1 \mathrm{H}), 1.50-1.66(\mathrm{~m}, 4 \mathrm{H}), 1.70-1.88$ (m, $2 \mathrm{H}$ ), 2.06-2.22 (m, $2 \mathrm{H}$ ), 4.67 (qintet, $1 \mathrm{H}$, all $J=2.9 \mathrm{~Hz}, \mathrm{CHBr}$ ); trans isomer $\delta 0.84\left(\mathrm{~s}, 9 \mathrm{H}, \mathrm{C}\left(\mathrm{CH}_{3}\right)_{3}\right), 0.91-1.83(\mathrm{~m}, 7 \mathrm{H}), 2.28-2.40$ $(\mathrm{m}, 2 \mathrm{H}), 3.96(\mathrm{tt}, 1 \mathrm{H}, J=11.8,4.0 \mathrm{~Hz}, \mathrm{CHBr})$. Retention times and spectral data are identical with those of material prepared by a literature procedure. ${ }^{6}$ Reactions at $4,30,50$, and $68^{\circ} \mathrm{C}$ all gave the same selectivity

4-tert-Butylcyclohexyl Chloride. In $25 \mathrm{~mL}$ of $\mathrm{CCl}_{4}$ is dissolved under argon $104 \mathrm{mg}(0.25 \mathrm{mmol})$ of trans-4-tert-butylcyclohexylmercury bromide. ${ }^{7}$ After the mixture is heated to $30^{\circ} \mathrm{C}$, a solution of $80 \mathrm{mg}(2.1$ mmol) $\mathrm{NaBH}_{4}$ in methanol ( $2 \mathrm{~mL}$ ) is added at once. Stirring is continued for $30 \mathrm{~min}$ and the reaction is filtered through anhydrous $\mathrm{MgSO}_{4}$ The solvent is evaporated and Kugelrohr distillation of the residue yields cis- and trans-4-tert-butylcyclohexyl chloride in a ratio of 23:77 (by GC and ${ }^{1} \mathrm{H}$ NMR). Retention times and spectral data are identical with those of material prepared by a literature procedure. ${ }^{27}$

trans- and cis-1-tert-Butyl-4-methylcyclohexane. 4-tert-Butyl-1methylcyclohexyl bromide (2) $(915 \mathrm{mg}, 3.9 \mathrm{mmol})$ and tri-n-butyltin hydride $(2.33 \mathrm{~g}, 2.1 \mathrm{mmol})$ are dissolved in benzene $(20 \mathrm{~mL})$ and heated to reflux. Within $4 \mathrm{~h}$ a solution of $40 \mathrm{mg}(0.24 \mathrm{mmol})$ of AIBN in benzene $(5 \mathrm{~mL})$ is added by syringe pump, and heating is continued for another $2 \mathrm{~h}$. The reaction mixture is worked up according to the $I_{2} / \mathrm{KF}$ method, and the residue is purified by chromatography on silica gel with pentane as the eluent. This yields $440 \mathrm{mg}(73 \%)$ of trans-1-tert-butyl4-methylcyclohexane and cis-1-tert-butyl-4-methylcyclohexane in a 89:11 ratio (by GC). Spectral data are identical with those published by Lambert et al. ${ }^{28}$

cis - and trans-4-tert-Butyl-1-methylcyclohexyl Chloride. To $170 \mathrm{mg}$ $(1.0 \mathrm{mmol})$ of 4-tert-butyl-1-methylcyclohexanol in benzene $(15 \mathrm{~mL})$ is added $1 \mathrm{~mL}$ of freshly distilled oxalic chloride at room temperature. After stirring for $12 \mathrm{~h}$, the solvent and excess oxalic chloride is evaporated and the residue is taken up in $5 \mathrm{~mL}$ of $\mathrm{CCl}_{4}$. This solution is added at reflux over $6 \mathrm{~h}$ to a suspension of $160 \mathrm{mg}(1.1 \mathrm{mmol})$ of 2 -mercaptopyridine $N$-oxide sodium salt and $4 \mathrm{mg}(0.03 \mathrm{mmol})$ of DMAP in 100 $\mathrm{mL}$ of tetrachloromethane. After addition is complete, heating is continued for $1 \mathrm{~h}$. The reaction mixture is filtrated through anhydrous 
$\mathrm{MgSO}_{4}$. By GC analysis of the filtrate a ratio for the cis-4-tert-butyland trans-4-tert-butyl-1-methylcyclohexyl chloride of $92: 8$ is found. Products are identified by comparison of their GC and NMR data with those published in the literature.

cis- and trans-1-tert-Butyl-trans-3-methyl-4-deuteriocyclohexane. [[(cis-4'-tert-Butyl-cis-2'-methylcyclohexyl)oxy]thiocarbonyl]imidazole (6b), $2.8 \mathrm{~g}(10 \mathrm{mmol})$, is dissolved in benzene $(10 \mathrm{~mL})$ and heated to reflux under argon. Within $3 \mathrm{~h}$ a solution of $4.9 \mathrm{~g}(17.0 \mathrm{mmol})$ of tri- $n$-butyltin deuteride and $360 \mathrm{mg}(2.2 \mathrm{mmol})$ of AIBN in benzene ( 5 $\mathrm{mL}$ ) is added with a syringe pump. After it is heated for $2 \mathrm{~h}$, the reaction mixture is worked up according to the KF procedure. Kugelrohr distillation $\left(90^{\circ} \mathrm{C} / 15 \mathrm{mbar}\right)$ gives $610 \mathrm{mg}(39 \%)$ of 1 -tert-butyl-3. methyl-4-deuteriocyclohexane as a mixture of the cis and trans isomers in a 56:44 ratio (by ${ }^{2} \mathrm{H}$ NMR). ${ }^{2} \mathrm{H}$ NMR $\left(46.07 \mathrm{MHz}, \mathrm{CHCl}_{3}\right.$ ): cis isomer $\delta 0.91$ (br s); trans isomer $\delta 1.77$ (br s).

cis-4-tert-Butyl-cis-2-methylcyclohexyl Bromide (6d) and trans-4tert-Butyl-trans-2-methylcyclobexyl Bromide (4d). To $330 \mathrm{mg}(2.0$ $\mathrm{mmol}$ ) of cis-4-tert-butyl-cis-2-methylcyclohexanol (6a) in benzene (15 $\mathrm{mL}$ ) was added $2 \mathrm{~mL}$ of freshly distilled oxalic chloride at room temperature. After stirring for $12 \mathrm{~h}$, the solvent and excess oxalic chloride are evaporated and the residue is taken up in $10 \mathrm{~mL}$ of toluene and 550 $\mathrm{mg}(2.8 \mathrm{mmol})$ of bromotrichloromethane. Within $6 \mathrm{~h}$ this solution is added at $80^{\circ} \mathrm{C}$ to a suspension of $330 \mathrm{mg}(2.2 \mathrm{mmol}) 2$-mercaptopyridine $N$-oxide sodium salt and $4 \mathrm{mg}(0.03 \mathrm{mmol})$ of DMAP in toluene $(50 \mathrm{~mL})$. After addition is complete, heating is continued for $1 \mathrm{~h}$. The solvent is evaporated and the residue is purified by flash chromatography on silica gel first with pentane and then with pentane-ethyl acetate (10:1) as eluent. This yields $38 \%(177 \mathrm{mg})$ of cis-4-tert-butyl-cis-2-methylcyclohexyl bromide (6d) and trans-4-tert-butyl-trans-2-methylcyclohexyl bromide (4d) in a 51:49 ratio (by GC and ${ }^{1} \mathrm{H}$ NMR). 'H NMR (300 $\left.\mathrm{MHz}, \mathrm{CDCl}_{3}\right):$ 6d $\delta 0.87\left(\mathrm{~s}, 9 \mathrm{H}, \mathrm{C}\left(\mathrm{CH}_{3}\right)_{3}\right), 1.11(\mathrm{~d}, J=6.4 \mathrm{~Hz}, 3 \mathrm{H}$ $\left.\mathrm{C}-2^{\prime}-\mathrm{CH}_{3}\right), 0.9-1.30(\mathrm{~m}, 4 \mathrm{H}), 1.36-1.62(\mathrm{~m}, 3 \mathrm{H}), 2.23(\mathrm{dq}, 1 \mathrm{H}, J=$ $14.6,3.3 \mathrm{~Hz}), 4.49(\mathrm{~m}, 1 \mathrm{H}, \mathrm{CHBr}) ;$ ad $\delta 0.84\left(\mathrm{~s}, 9 \mathrm{H}, \mathrm{C}\left(\mathrm{CH}_{3}\right)_{3}\right), 0.99$ $\left(\mathrm{d}, J=6.3,3 \mathrm{H}, \mathrm{C}-2^{\prime}-\mathrm{CH}_{3}\right), 0.90-1.30(\mathrm{~m}, 4 \mathrm{H}), 1.36-1.62(\mathrm{~m}, 3 \mathrm{H})$, $2.39(\mathrm{dq}, 1 \mathrm{H}, J=12.9,3.8 \mathrm{~Hz}), 3.64(\mathrm{td}, 1 \mathrm{H}, J=11.4,4.2 \mathrm{~Hz}, \mathrm{CHBr})$. ${ }^{13} \mathrm{C}$ NMR (75.5 MHz, CDCl $\left.)_{3}\right)$ od $\delta 63.90(\mathrm{C}-1), 47.43(\mathrm{C}-4), 37.65$ (C-2), $36.54(\mathrm{C}-6), 32.29\left(\mathrm{C}\left(\mathrm{CH}_{3}\right)\right), 29.52(\mathrm{C}-3), 27.28\left(\mathrm{C}\left(\mathrm{CH}_{3}\right)_{3}\right)$, 21.75 (C-5), 20.89 (C-2- $\left.H_{3}\right)$; $4 \mathrm{~d} \delta 61.94$ (C-1), 47.23 (C-4), $41.66(\mathrm{C}-2)$ $39.01(\mathrm{C}-6), 32.29\left(\mathrm{C}\left(\mathrm{CH}_{3}\right)_{3}\right), 29.52(\mathrm{C}-3), 27.28\left(\mathrm{C}\left(\mathrm{CH}_{3}\right)_{3}\right), 21.75$ (C-5), $20.89\left(\mathrm{C}-2-\mathrm{CH}_{3}\right)$. MS (EI): $152\left(\mathrm{M}^{+}-\mathrm{HBr}, 11 \%\right), 137\left(\mathrm{M}^{+}\right.$ $\left.-\mathrm{HBr}-\mathrm{CH}_{3}, 24 \%\right), 57(t-\mathrm{Bu}, 100 \%)$.

cis-4-tert-Butyl-cis-2-methylcyclohexyl Chloride (6e) and trans-4tert-Butyl-trans-2-methylcyclohexyl Chloride (4e). To $170 \mathrm{mg}(1.0$ $\mathrm{mmol}$ ) of cis-4-tert-butyl-cis-2-methylcyclohexanol (6a) in benzene (15 $\mathrm{mL}$ ) are added $2 \mathrm{~mL}$ of freshly distilled oxalic chloride at room temperature. After stirring for $12 \mathrm{~h}$, the solvent and excess oxalic chloride are evaporated and the residue is taken up in $5 \mathrm{~mL}$ of $\mathrm{CCl}_{4}$. Within 6 $\mathrm{h}$ this solution is added at reflux to a suspension of $160 \mathrm{mg}(1.1 \mathrm{mmol})$ of 2-mercaptopyridine $N$-oxide sodium salt and $4 \mathrm{mg}(0.03 \mathrm{mmol})$ of DMAP in tetrachloromethane $(100 \mathrm{~mL})$. After addition is complete, heating is continued for $1 \mathrm{~h}$. The reaction mixture is filtered through anhydrous $\mathrm{MgSO}_{4}$, the solvent is removed, and the residue is purified by Kugelrohr distillation $\left(140^{\circ} \mathrm{C} / 15 \mathrm{mbar}\right)$ to yield $290 \mathrm{mg}(77 \%)$ of 4 . tert-butyl-2-methylcyclohexyl chloride as a mixture of the cis and trans isomers 6e and $4 \mathrm{e}$ in a ratio of $56: 44$ (by GC). ${ }^{1} \mathrm{H}$ NMR $(300 \mathrm{MHz}$, $\left.\mathrm{CDCl}_{3}\right)$ : 6e $\delta 0.87\left(\mathrm{~s}, 9 \mathrm{H}, \mathrm{C}\left(\mathrm{CH}_{3}\right)_{3}\right), 0.88\left(\mathrm{~d}, J=6.6 \mathrm{~Hz}, 3 \mathrm{H}, \mathrm{C}-2^{\prime}-\right.$ $\left.\mathrm{CH}_{3}\right), 0.95-1.87(\mathrm{~m}, 6 \mathrm{H}), 1.20\left(\mathrm{q}, 1 \mathrm{H}, J=12.5 \mathrm{~Hz}, \mathrm{C}-3-H_{\mathrm{ax}}\right), 2.12$ $(\mathrm{dq}, 1 \mathrm{H}, J=14.2,3.3 \mathrm{~Hz}), 4.25(\mathrm{q}, 1 \mathrm{H}, J=2.6 \mathrm{~Hz}, \mathrm{C} H \mathrm{Cl}) ; 4 \mathrm{e} \delta 0.84$ (s, $\left.9 \mathrm{H}, \mathrm{C}\left(\mathrm{CH}_{3}\right)_{3}\right), 1.09$ (d, $\left.J=6.4 \mathrm{~Hz}, 3 \mathrm{H}, \mathrm{C}-2^{\prime}-\mathrm{CH}_{3}\right), 0.95-1.87(\mathrm{~m}$, $6 \mathrm{H}), 1.20\left(\mathrm{q}, 1 \mathrm{H}, J=12.5 \mathrm{~Hz}, \mathrm{C}-3-H_{\mathrm{ax}}\right), 2.25(\mathrm{dq}, 1 \mathrm{H}, J=12.8,4.3$ $\mathrm{Hz}), 3.42$ (ddd, $1 \mathrm{H}, J=11.6,10.7,4.4 \mathrm{~Hz}, \mathrm{CHCl}) .{ }^{13} \mathrm{C}$ NMR $(75.5$ $\left.\mathrm{MHz}, \mathrm{CDCl}_{3}\right): 6$ e $\delta 66.53$ (C-1), 47.63 (C-4), 37.89 (C-6), 37.61 (C-2) $\left.32.47\left(\mathrm{C}_{(\mathrm{CH}}\right)_{3}\right), 28.94(\mathrm{C}-3), 27.58\left(\mathrm{C}\left(\mathrm{CH}_{3}\right)_{3}\right), 20.70\left(\mathrm{C}-2-\mathrm{CH}_{3}\right) 20.29$ (C-5); 4 e $\delta 67.88$ (C-1), 47.25 (C-4), 41.39 (C-2), 36.21 (C-6), 35.07 $(\mathrm{C}-3), 32.23\left(\mathrm{C}\left(\mathrm{CH}_{3}\right)_{3}\right), 27.58\left(\mathrm{C}\left(\mathrm{CH}_{3}\right)_{3}\right), 27.50(\mathrm{C}-5), 20.56(\mathrm{C}-2-\mathrm{C}-$ $\left.\mathrm{H}_{3}\right)$. MS (EI) $137\left(\mathrm{M}^{+}-\mathrm{HBr}-\mathrm{CH}_{3}, 7 \%\right), 130 / 132\left(1: 3, \mathrm{M}^{+}-57,4 \%\right)$, $57(t-\mathrm{Bu}, 100 \%)$. Anal. Calcd for $\mathrm{C}_{11} \mathrm{H}_{21} \mathrm{~N}_{\mathrm{Cl}}: \mathrm{C}, 70.00 ; \mathrm{H}, 11.22$ Found: $C, 70.90 ; \mathrm{H}, 11.54$

cis -4-tert-Butyl-trans -2-methylcyclohexyl Bromide (7d) and trans -4tert-Butyl-cis-2-methylcyclohexyl Bromide (5d). cis-4-tert-Butyltrans-2-methylcyclohexanol (7a), $110 \mathrm{mg}(0.65 \mathrm{mmol})$, and $3 \mathrm{~mL}$ of freshly distilled oxalyl chloride are stirred in benzene $(10 \mathrm{~mL})$ for $12 \mathrm{~b}$ at $20^{\circ} \mathrm{C}$. The solvent and excess oxalyl chloride are removed in vacuo and $149 \mathrm{mg}(0.76 \mathrm{mmol})$ of $\mathrm{BrCCl}_{3}$ are added with benzene $(6 \mathrm{~mL})$. Within $5 \mathrm{~h}$ this solution is added at $80^{\circ} \mathrm{C}$ to a suspension of $107 \mathrm{mg}$ $(0.72 \mathrm{mmol})$ of 2-mercaptopyridine $N$-oxide sodium salt and $3 \mathrm{mg}(0.024$ mmol) of DMAP in benzene $(15 \mathrm{~mL})$. Heating is continued for $1 \mathrm{~h}$. Then the reaction mixture is filtered through anhydrous $\mathrm{MgSO}_{4}$, the solvent is distilled off, and the residue is purified by flash chromatography on silica gel first with pentane and then with pentane-ethyl acetate
Table IV

\begin{tabular}{|c|c|c|c|c|c|c|}
\hline 23 & 03 & 0 & 20 & & & \\
\hline 29 & 28 & 2 & 1 & 0.0 & -25.0 & 0.0 \\
\hline 29 & 28 & 2 & 4 & 0.0 & -25.0 & 0.0 \\
\hline 29 & 28 & 2 & 5 & 0.0 & -25.0 & 0.0 \\
\hline 5 & 2 & 28 & 5 & 0.0 & 0.0 & 0.25 \\
\hline 5 & 2 & 28 & 1 & 0.0 & 0.2 & 0.2 \\
\hline 4 & 2 & 28 & 5 & 0.0 & 0.0 & 0.34 \\
\hline 1 & 2 & 28 & 5 & 0.0 & 0.0 & 0.34 \\
\hline 1 & 2 & 28 & 1 & 0.4 & 0.03 & 0.5 \\
\hline 5 & 29 & 28 & 5 & 0.0 & 0.0 & 0.0267 \\
\hline 1 & 29 & 28 & 5 & 0.0 & 0.0 & 0.0273 \\
\hline 5 & 29 & 28 & 2 & 0.0 & 0.0 & 0.0405 \\
\hline 5 & 29 & 28 & 1 & 0.0 & 0.0 & 0.0646 \\
\hline 1 & 29 & 28 & 2 & -0.241 & 0.241 & 0.399 \\
\hline 1 & 29 & 28 & 1 & 1.364 & -1.103 & 0.399 \\
\hline 5 & 1 & 2 & 28 & 0.0 & 0.0 & -0.24 \\
\hline 1 & $i$ & 2 & 28 & -0.44 & 0.24 & 0.06 \\
\hline 28 & 29 & 1 & 5 & 0.0 & 0.40 & 0.267 \\
\hline 1 & 28 & 2 & 4 & 0.0 & 0.0 & 0.010 \\
\hline 4 & 28 & 2 & 4 & 0.0 & 0.0 & 0.1 \\
\hline 1 & 1 & 29 & 28 & 0.47 & -0.2538 & 0.13 \\
\hline 1 & 1 & 29 & 1 & 0.15 & 0.25 & 0.0 \\
\hline 1 & 1 & 29 & 5 & 0.0 & -0.05 & 0.27 \\
\hline 5 & 1 & 29 & 5 & 0.0 & 0.0 & 0.3 \\
\hline 29 & 28 & & & 4.0 & 2.27 & \\
\hline 28 & 2 & & & 4.4 & 1.375 & \\
\hline 2 & 4 & & & 9.66 & 1.427 & \\
\hline 5 & 29 & 5 & & 0.32 & 116.6 & \\
\hline 5 & 29 & 28 & & 0.36 & 100.5 & \\
\hline 29 & 28 & 5 & & 0.36 & 90.3 & \\
\hline 29 & 28 & 2 & & 0.60 & 107.0 & \\
\hline 29 & 28 & 4 & & 0.45 & 96.56 & \\
\hline 5 & 28 & 2 & & 0.36 & 120.3 & \\
\hline 5 & 28 & 5 & & 0.32 & 115.8 & \\
\hline 28 & 2 & 5 & & 0.36 & 121.4 & \\
\hline 5 & 2 & 5 & & 0.32 & 117.0 & \\
\hline 1 & 29 & 5 & & 0.36 & 116.6 & \\
\hline 1 & 29 & 1 & & 0.45 & 116.6 & \\
\hline 1 & 29 & 28 & & 0.45 & 100.5 & \\
\hline 29 & 28 & 1 & & 0.45 & 98.22 & \\
\hline 1 & 28 & 2 & & 0.45 & 120.3 & \\
\hline 1 & 28 & 5 & & 0.36 & 115.8 & \\
\hline 1 & 28 & 1 & & 0.45 & 115.8 & \\
\hline 28 & 2 & 1 & & 0.45 & 121.4 & \\
\hline 5 & 2 & 1 & & 0.36 & 117.0 & \\
\hline 2 & 4 & 10 & & 0.47 & 180.0 & \\
\hline 2 & 28 & 4 & & 0.45 & 120.0 & \\
\hline
\end{tabular}

(19:1). This yields $65 \mathrm{mg}$ (42\%) of cis-4-tert-butyl-trans-2-methylcyclohexyl bromide (7d) and trans-4-tert-butyl-cis-2-methylcyclohexyl bromide (5d) in a 85:15 ratio (by GC and ${ }^{1} \mathrm{H}$ NMR). ${ }^{1} \mathrm{H}$ NMR (300 $\left.\mathrm{MHz}, \mathrm{CDCl}_{3}\right): 7 \mathrm{~d} \delta 0.88\left(\mathrm{~s}, 9 \mathrm{H}, \mathrm{C}\left(\mathrm{CH}_{3}\right)_{3}\right), 1.08(\mathrm{~d}, 3 \mathrm{H}, J=7.3 \mathrm{~Hz}$, $\left.\mathrm{C}-2^{\prime}-\mathrm{CH}_{3}\right), 1.20-1.45(\mathrm{~m}, 3 \mathrm{H}), 1.50-1.60(\mathrm{~m}, 2 \mathrm{H}), 1.70-2.00(\mathrm{~m}, 2$ $\mathrm{H}), 2.2-2.4(\mathrm{~m}, 1 \mathrm{H}), 4.35-4.40(\mathrm{~m}, 1 \mathrm{H}, \mathrm{CHBr}) ; 5 \mathrm{~d} \delta 0.83(\mathrm{~s}, 9 \mathrm{H}$, $\left.\mathrm{C}\left(\mathrm{CH}_{3}\right)_{3}\right), 1.15\left(\mathrm{~d}, 3 \mathrm{H}, J=7.3 \mathrm{~Hz}, \mathrm{C}-2^{\prime}-\mathrm{CH}_{3}\right), 1.20-1.45(\mathrm{~m}, 3 \mathrm{H})$, $1.50-1.60(\mathrm{~m}, 2 \mathrm{H}), 1.70-2.00(\mathrm{~m}, 2 \mathrm{H}), 2.20-2.40(\mathrm{~m}, 1 \mathrm{H}), 4.25-4.35$ (m, $1 \mathrm{H}, \mathrm{CHBr}) .{ }^{13} \mathrm{C}$ NMR $\left(75.5 \mathrm{MHz}, \mathrm{CDCl}_{3}\right): 7 \mathrm{~d} \delta 59.29(\mathrm{C}-1)$, 40.59 (C-4), $36.99(\mathrm{C}-2), 32.11\left(\mathrm{C}\left(\mathrm{CH}_{3}\right)_{3}\right), 29.74(\mathrm{C}-5), 27.19$ (C) $\mathrm{C}$ $\left.\left.\mathrm{H}_{3}\right)_{3}\right), 26.92(\mathrm{C}-6), 21.72(\mathrm{C}-3), 18.58\left(\mathrm{C}-2-\mathrm{CH}_{3}\right)$; 5 d 858.97 (C-1), 39.20 (C-4), $\left.35.72(\mathrm{C}-2), 34.11(\mathrm{C}-5), 31.88\left(\mathrm{C}_{(\mathrm{H}}\right)_{3}\right), 29.51(\mathrm{C}-6)$, $28.97(\mathrm{C}-3), 27.19\left(\mathrm{C}\left(\mathrm{CH}_{3}\right)_{3}\right), 13.83\left(\mathrm{C}-2^{\prime}-\mathrm{CH}_{3}\right) \mathrm{MS}(\mathrm{EI}): 152\left(\mathrm{M}^{+}\right.$ - $\mathrm{HBr}, 19 \%), 137\left(\mathrm{M}^{+}-\mathrm{HBr}-\mathrm{CH}_{3}, 15 \%\right), 57(t-\mathrm{Bu}, 100 \%)$. Anal. Caled for $\mathrm{C}_{11} \mathrm{H}_{21} \mathrm{~N}_{\mathrm{Br}}$ : $\mathrm{C}, 56.63 ; \mathrm{H}, 9.07$. Found: $\mathrm{C}, 56.81 ; \mathrm{H}, 9.15$.

cis -4-tert -Butyl-trans -2-methylcyclohexyl Chloride (7e) and trans -4tert-Butyl-cis-2-methylcyclohexyl Chloride (5e). cis-4-tert-Butyl-trans2 -methylcyclohexanol $(7 \mathrm{a}), 170 \mathrm{mg}(1.0 \mathrm{mmol})$, in benzene $(5 \mathrm{~mL})$ are added to $1 \mathrm{~mL}$ of freshly distilled oxylyl chloride in $3 \mathrm{~mL}$ of benzene. After stirring for $6 \mathrm{~h}$, the solvent and excess oxalyl chloride are removed in vacuo and the residue is taken up in $5 \mathrm{~mL}$ of $\mathrm{CCl}_{\text {. }}$ 2-Mercaptopyridine $N$-oxide sodium salt, $164 \mathrm{mg}(1.1 \mathrm{mmol})$, and DMAP, $8 \mathrm{mg}$ $(0.065 \mathrm{mmol})$, are suspended in benzene $(15 \mathrm{~mL})$ and a $\mathrm{CCl}_{4}$ solution is added under reflux within $2 \mathrm{~h}$. Heating is continued for $1 \mathrm{~h}$. Then the reaction mixture is filtered through anhydrous $\mathrm{MgSO}_{4}$, the solvent is distilled of, and the residue is purified by flash chromatography on silica gel first with pentane and then with pentane-ethyl acetate (19:1). This yields $115 \mathrm{mg}(90 \%)$ of cis-4-tert-butyl-trans-2-methylcyclohexyl chloride (7e) and trans-4-tert-butyl-cis-2-methylcyclohexyl chloride (5e) in a 86:14 ratio (by GC and ${ }^{1} \mathrm{H}$ NMR). ${ }^{t} \mathrm{H}$ NMR $\left(300 \mathrm{MHz}, \mathrm{CDCl}_{3}\right)$ : 
7e $\delta 0.86\left(\mathrm{~s}, 9 \mathrm{H}, \mathrm{C}\left(\mathrm{CH}_{3}\right)_{3}\right), 1.05$ (d, $\left.3 \mathrm{H}, J=7.4 \mathrm{~Hz}, \mathrm{C}-2{ }^{\prime}-\mathrm{CH}_{3}\right)$, $1.18-1.42(\mathrm{~m}, 4 \mathrm{H}), 1.46-1.56(\mathrm{~m}, 2 \mathrm{H}), 1.65-2.00(\mathrm{~m}, 3 \mathrm{H}), 2.18-2.34$ $(\mathrm{m}, 1 \mathrm{H}), 4.18(\mathrm{~m}, 1 \mathrm{H}, \mathrm{CHCl}) ;$ se $\delta 0.84\left(\mathrm{~s}, 9 \mathrm{H}, \mathrm{C}\left(\mathrm{CH}_{3}\right)_{3}\right), 1.08(\mathrm{~d}$, $\left.3 \mathrm{H}, J=5.2 \mathrm{~Hz}, \mathrm{C}-2^{\prime}-\mathrm{CH}_{3}\right), 1.18-1.42(\mathrm{~m}, 4 \mathrm{H}), 1.46-1.56(\mathrm{~m}, 2 \mathrm{H})$, $1.65-2.00(\mathrm{~m}, 3 \mathrm{H}), 2.18-2.34(\mathrm{~m}, 1 \mathrm{H}), 4.72(\mathrm{~m}, 1 \mathrm{H}, J=12.7,4.8 \mathrm{~Hz}$, $\mathrm{CHCl}) .{ }^{13} \mathrm{C}$ NMR $\left(75.5 \mathrm{MHz}, \mathrm{CDCl}_{3}\right): 7 \mathrm{e} \delta 64.15$ (C-1), $40.71(\mathrm{C}-4)$,

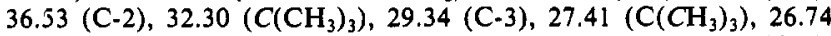
(C-6), 21.13 (C-5), $18.49\left(\mathrm{C}-2-\mathrm{CH}_{3}\right)$; 5e $\delta 64.71$ (C-1), 39.49 (C-4), 35.39 (C-2), 33.81 (C-3), $31.91\left(\mathrm{C}\left(\mathrm{CH}_{3}\right)_{3}\right), 29.69$ (C-5), 27.88 (C-6), $27.47\left(\mathrm{C}\left(\mathrm{CH}_{3}\right)_{3}\right), 12.63\left(\mathrm{C2}^{\prime}-\mathrm{CH}_{3}\right)$. High-resolution MS (EI) calcd for $\mathrm{C}_{11} \mathrm{H}_{21}$ : 153.1643. Found: $153.1639,\left(\mathrm{M}^{+}-\mathrm{Cl}, 0.5 \%\right), 137\left(\mathrm{M}^{+}-\mathrm{HCl}\right.$ $\left.-\mathrm{CH}_{3}, 11 \%\right), 96(26 \%), 57(t-\mathrm{Bu}, 100 \%)$

$2 \alpha \beta$-Bromo-10-methyl-trans-decalin. To $20 \mathrm{~mL}$ of benzene are added $3.0 \mathrm{~mL}$ of freshly distilled oxalyl chloride and $770 \mathrm{mg}(4.6 \mathrm{mmol})$ of 2 $\beta$-hydroxy-10-methyl-trans-decalin (12). After the mixture was stirred for $12 \mathrm{~h}$, the solvent and excess oxalyl chloride are removed in vacuo and the residue taken up in benzene $(10 \mathrm{~mL})$ and $1.4 \mathrm{~mL}$ of $\mathrm{BrCCl}_{3}$. This solution is added within $5 \mathrm{~h}$ to a refluxing suspension of $756 \mathrm{mg}$ (5.1 mmol) of 2 -mercaptopyridine $N$-oxide sodium salt and $10 \mathrm{mg}(0.08$ mmol) of DMAP in benzene $(150 \mathrm{~mL})$. Heating is continued for $3 \mathrm{~h}$. The reaction mixture is filtered through anhydrous $\mathrm{MgSO}_{4}$ and the solvent is evaporated. Flash chromatography on silica gel with pentane yields $424 \mathrm{mg}(40 \%)$ of 2 -bromo-10-methyl-trans-decalin as a mixture of the $2 \alpha$-and $2 \beta$-isomers in a 91:9 ratio (by ${ }^{~} \mathrm{H}$ NMR). ${ }^{1} \mathrm{H}$ NMR (300 $\left.\mathrm{MHz}, \mathrm{CDCl}_{3}\right): 2 \alpha$-isomer $\delta 0.85\left(\mathrm{~s}, 3 \mathrm{H}, \mathrm{C}-10-\mathrm{CH}_{3}\right), 1.05-1.85(\mathrm{~m}, 13$ $\mathrm{H}), 1.95-2.05(\mathrm{~m}, 1 \mathrm{H}), 2.25-2.40(\mathrm{~m}, 1 \mathrm{H}), 4.30(\mathrm{tt}, 1 \mathrm{H}, J=12.3,4.4$ $\mathrm{Hz}, \mathrm{CHBr}) ; 2 \beta$-isomer $\delta 0.88\left(\mathrm{~s}, 3 \mathrm{H}, \mathrm{C}-10-\mathrm{CH}_{3}\right), 1.05-1.95(\mathrm{~m}, 13 \mathrm{H})$, $2.15-2.25(\mathrm{~m}, 1 \mathrm{H}), 4.67(\mathrm{~m}, 1 \mathrm{H}, \mathrm{CHBr}) .{ }^{13} \mathrm{C}$ NMR $(75.5 \mathrm{MHz}$, $\mathrm{CDCl}_{3}$ ): $2 \alpha$-isomer $\delta 53.28$ (C-1), 49.79 (C-2), 44.34 (C-5), 41.15 (C-9), 39.09 (C-3), 37.10 (C-10), 30.31 (C-4), 28.03 (C-6), 26.69 (C-7), 21.13 (C-8), $15.84\left(\mathrm{C}-10-\mathrm{CH}_{3}\right) ; \beta$-isomer $\delta 51.20(\mathrm{C}-2), 48.42(\mathrm{C}-1), 45.85$ (C-5), 41.86 (C-9), 36.92 (C-3), 34.20 (C-10), 28.33 + 26.90 (C-6 + C-7), $24.35(\mathrm{C}-4), 20.91(\mathrm{C}-8), 18.34\left(\mathrm{C}-10-\mathrm{CH}_{3}\right) . \mathrm{MS}(\mathrm{EI}): 230\left(\mathrm{M}^{+}\right.$ $0.9 \%), 151\left(\mathrm{M}^{+}-\mathrm{Br}, 85 \%\right), 95\left(\mathrm{M}^{+}-135,100 \%\right)$. Anal. Calcd for $\mathrm{C}_{11} \mathrm{H}_{19} \mathrm{Br}$ : C, 57.15; H, 8.28. Found: $\mathrm{C}, 57.20 ; \mathrm{H}, 8.10$.

$2 \alpha \beta$-Chloro-10-methyl-trans-decalin. In benzene $(10 \mathrm{~mL})$ are placed $1.5 \mathrm{~mL}$ of freshly distilled oxalyl chloride and $274 \mathrm{mg}(1.63 \mathrm{mmol})$ of $2 \beta$-hydroxy-10-methyl-trans-decalin (12). After the mixture is stirred for $12 \mathrm{~h}$, the solvent and excess oxalyl chloride are evaporated and the residue taken up in $5 \mathrm{~mL}$ of $\mathrm{CCl}_{4}$. This solution is added within $15 \mathrm{~min}$ to a refluxing suspension of $270 \mathrm{mg}(1.8 \mathrm{mmol})$ of 2 -mercaptopyridine $N$-oxide sodium salt and $8 \mathrm{mg}(0.065 \mathrm{mmol})$ of DMAP in $\mathrm{CCl}_{4}(150$ $\mathrm{mL}$ ). Heating is continued for $30 \mathrm{~min}$. Then the reaction mixture is filtered through anhydrous $\mathrm{MgSO}_{4}$ and the solvent is evaporated. Flash chromatography on silica gel with pentane yields $223 \mathrm{mg}(73 \%)$ of 2 chloro-10-methyl-trans-decalin as an inseparable mixture of the $2 \alpha$ - and $2 \beta$-isomers in a 9:1 ratio (by GC and ${ }^{1} \mathrm{H}$ NMR). ${ }^{1} \mathrm{H} \mathrm{NMR}$ ( $300 \mathrm{MHz}$, $\left.\mathrm{CDCl}_{3}\right): 2 \alpha$-isomer $\delta 0.85\left(\mathrm{~s}, 3 \mathrm{H}, \mathrm{C}-10-\mathrm{CH}_{3}\right), 1.05-1.76(\mathrm{~m}, 13 \mathrm{H})$, $1.84-1.94(\mathrm{~m}, 1 \mathrm{H}), 2.17-2.27(\mathrm{~m}, 1 \mathrm{H}), 4.11(\mathrm{tt}, 1 \mathrm{H}, J=12.0,4.4 \mathrm{~Hz}$, $\mathrm{CHCl}) ; 2 \beta$-isomer $\delta 0.85\left(\mathrm{~s}, 3 \mathrm{H}, \mathrm{C}-10-\mathrm{CH}_{3}\right), 1.05-1.76(\mathrm{~m}, 13 \mathrm{H})$, $1.84-1.94(\mathrm{~m}, 1 \mathrm{H}), 2.03-2.13(\mathrm{~m}, 1 \mathrm{H}), 4.47(\mathrm{~m}, 1 \mathrm{H}, \mathrm{CHCl}) .{ }^{13} \mathrm{C}$ NMR (75.5 MHz, $\mathrm{CDCl}_{3}$ ): $2 \alpha$-isomer $\delta 57.15$ (C-2), $52.32(\mathrm{C}-1), 44.42$ (C-5), 41.20 (C-9), 38.10 (C-3), 36.08 (C-10), 29.27 (C-4), 27.95 (C-6), 26.75 (C-7), $21.12(\mathrm{C}-8), 16.01\left(\mathrm{C}-10-\mathrm{CH}_{3}\right) ; 2 \beta$-isomer $\delta 58.60(\mathrm{C}-2)$, 47.97 (C-1), 45.90 (C-5), 41.74 (C-9), 35.85 (C-3), 34.10 (C-10), 29.70 (C-4), 28.38 (C-6), 26.92 (C-7), 20.98 (C-8), $18.04\left(\mathrm{C}-10-\mathrm{CH}_{3}\right)$. High-resolution MS (EI) calcd for $\mathrm{C}_{11} \mathrm{H}_{19} \mathrm{Cl}: 186.117$. Found: 186.117 $\left(\mathrm{M}^{+}, 55 \%\right), 171\left(\mathrm{M}^{+}-\mathrm{CH}_{3}, 16 \%\right), 135\left(\mathrm{M}^{+}-\mathrm{HCl}-\mathrm{CH}_{3}, 100 \%\right)$.

Acknowledgment. We are grateful to the Swiss National Fonds and the National Science Foundation for financial support and to $M$. Zehnder and S. Neuenburger for solving the X-ray crystal structure.

\section{Appendix}

New MM2 Parameters. Our MM2 results can be reproduced with the parameters listed here. The radical center is defined as MM2 type 29, while the alkene atom being attacked is of type 28 . The alkene carbon atom not attacked remains type 2 ( $\mathrm{sp}^{2}$ carbon). Calculations were carried out with Allinger's MM2 program ${ }^{29}$ modified by Spellmeyer and Houk. ${ }^{21}$ The modified program version allows the equivalence of two atom types. This enables the user to input only the parameters newly defined for a new atom type. The parameters, which are read in at the beginning of the calculation, are given in Table IV in the MM2 input format. The list contains the 33 parameters developed for the intramolecular 5-hexenyl cyclization and those 10 parameters added in the present study.

Supplementary Material Available: Tables of geometrical data for the $a b$ initio transition states in Figure 1 and the UHF/3-21G geometry of the cyclohexyl radical and data for the X-ray crystal structure and NMR spectra (18 pages). Ordering information is given on any current masthead page.

\title{
Photochemical Reactions of Chromium-Alkoxycarbene Complexes with Stabilized Ylides To Produce "Push-Pull" Captodative Allenes
}

\author{
Michael R. Sestrick, Michael Miller, and Louis S. Hegedus* \\ Contribution from the Department of Chemistry, Colorado State University, Fort Collins, \\ Colorado 80523. Received September 18, 1991
}

\begin{abstract}
Photolysis of chromium alkoxycarbene complexes in the presence of stabilized ylides produced allenes having electron withdrawing groups on $\mathrm{C}-1$ and electron donating groups on $\mathrm{C}-3$. These highly reactive captodative allenes rearranged to 1,3-substituted-1,3-dienes under mildly acidic conditions and hydrolyzed to $\gamma$-keto- $\alpha, \beta$-unsaturated esters, both in excellent yield.
\end{abstract}

\section{Introduction}

Over the past several years the photochemical reactions of chromium-carbene complexes has been extensively developed in these laboratories. Photolysis of these complexes (visible light/Pyrex) generates a reactive intermediate that undergoes reactions common to ketenes, ${ }^{1}$ and this chemistry has been used

(1) Hegedus, L. S.; deWeck, G.; D’Andrea, S. J. Am. Chem. Soc. 1988 110,2122 . to synthesize $\beta$-lactams, ${ }^{2}$ cyclobutanones, ${ }^{3}$ and $\alpha$-amino acid esters ${ }^{4}$ (Scheme I). In an effort to extend the parallels between con-

(2) (a) Hegedus, L. S.; McGuire, M. A.; Schultze, L. M; Yijun, C.; Anderson, O. P. J. Am. Chem. Soc. 1984, 106, 2680. (b) Hegedus, L. S. Schultze, L. M.; Toro, J.; Yijun, C. Tetrahedron 1985, 41, 5833. (c) Borel, C.; Hegedus, L. S.; Krebs, J.; Satoh, Y. J. Am. Chem. Soc. 1987, 109, 1101. (d) Hegedus, L. S.; D'Andrea, S. J. Org. Chem. 1988, 53, 3113. (e) Hegedus, L. S.; Imwinkelried, R.; Alarid-Sargent, M.; Dvorak, D.; Satoh, Y. J. Am Chem. Soc. 1990, 112, 1109. 